(1) norden

\title{
Towards a Nordic textile strategy
}

Collection, sorting, reuse and recycling of textiles

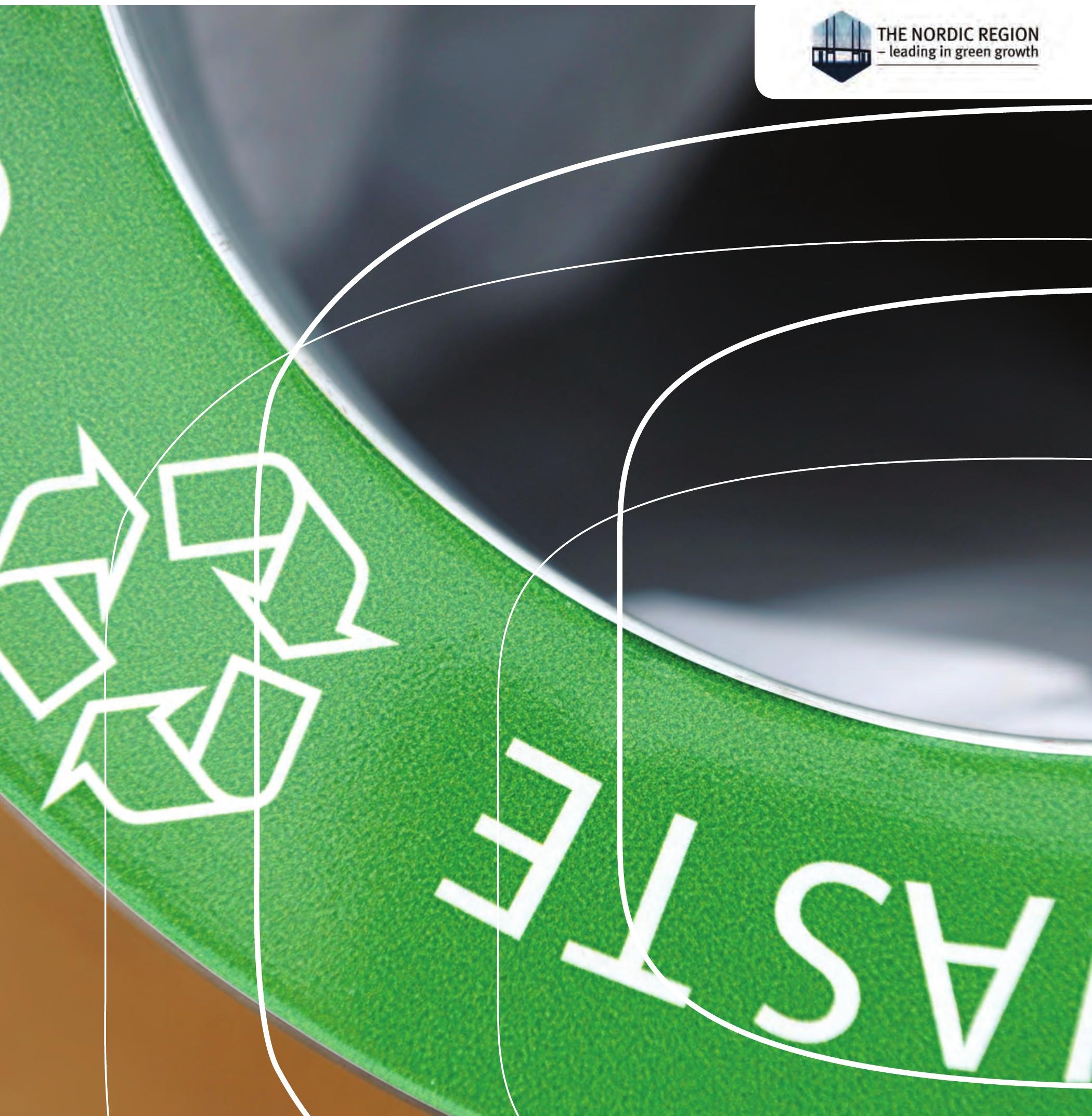



4 norden 



\section{Towards a Nordic textile strategy}

Collection, sorting, reuse and recycling of textiles

David Palm, Maria Elander, David Watson, Nikola Kiørboe,

Hanna Salmenperä, Helena Dahlbo, Katja Moliis, Kari-Anne Lyng, Clara Valente, Stefán Gíslason, Haben Tekie and Tomas Rydberg 
Towards a Nordic textile stra-tegy

Collection, sorting, reuse and recycling of textiles

David Palm, Maria Elander, David Watson, Nikola Kiørboe, Hanna Salmenperä, Helena Dahlbo,

Katja Moliis, Kari-Anne Lyng, Clara Valente, Stefán Gíslason, Haben Tekie andTomas Rydberg

ISBN 978-92-893-2794-7

ISBN 978-92-893-2795-4 (EPUB)

http://dx.doi.org/10.6027/TN2014-538

TemaNord 2014:538

ISSN 0908-6692

(C) Nordic Council of Ministers 2014

Layout: Hanne Lebech

Cover photo: Johannes Jansson

COPENHAGEN

WASTE CONSUMPTION - PRODUCTION

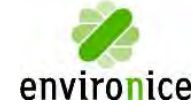

TW Svenska

environice

\section{$\perp$ Miljöinstitutet}

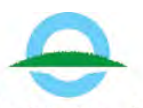

S Y K E
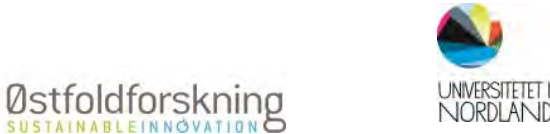

This publication has been published with financial support by the Nordic Council of Ministers. However, the contents of this publication do not necessarily reflect the views, policies or recommendations of the Nordic Council of Ministers.

\section{www.norden.org/en/publications}

\section{Nordic co-operation}

Nordic co-operation is one of the world's most extensive forms of regional collaboration, involving Denmark, Finland, Iceland, Norway, Sweden, and the Faroe Islands, Greenland, and Åland.

Nordic co-operation has firm traditions in politics, the economy, and culture. It plays an important role in European and international collaboration, and aims at creating a strong Nordic community in a strong Europe.

Nordic co-operation seeks to safeguard Nordic and regional interests and principles in the global community. Common Nordic values help the region solidify its position as one of the world's most innovative and competitive.

\section{Nordic Council of Ministers}

Ved Stranden 18

DK-1061 Copenhagen K

Phone (+45) 33960200

\section{www.norden.org}




\section{Content}

Key messages
Introduction
Background
The project
Summary of the reports

International market survey ....................................................................................... 19

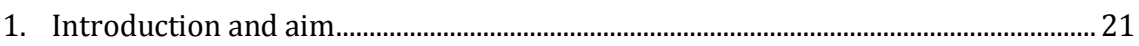

2. Overview of textile flows in the Nordic region.......................................................... 23

2.1 Denmark .......................................................................................................... 23

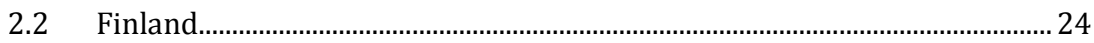

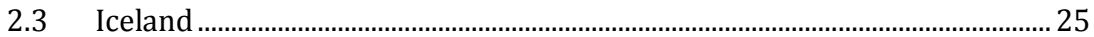

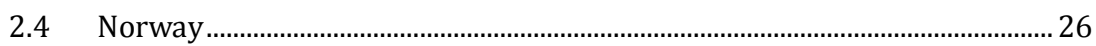

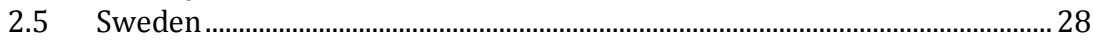

3. The Nordic market for used textiles and textile waste for recycling ......................... 31

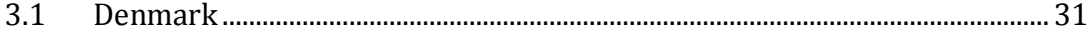

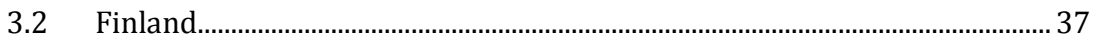

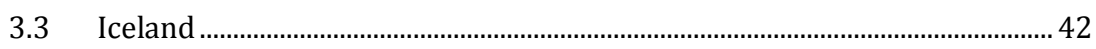

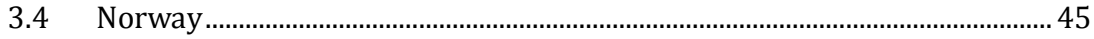

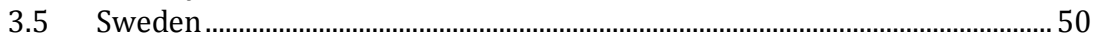

3.6 Summary of Nordic Flows and Markets ..........................................................5 59

4. The European market for used textiles and textile waste for recycling ...................65 65

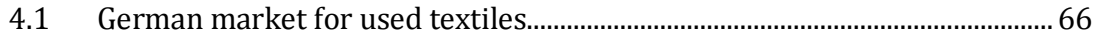

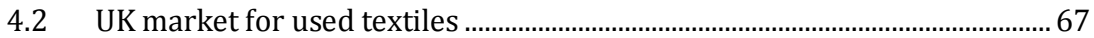

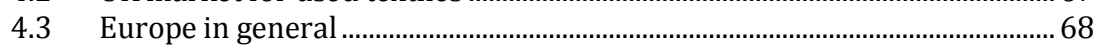

5. The global market for used textiles and textile waste for recycling.........................69

5.1 Actors in the market for collecting and sorting used textiles..........................69

$5.2 \quad$ Global trade patterns of used textiles .............................................................. 70

$5.3 \quad$ Global recycling of used textiles....................................................................... 71

6. Summary of main drivers and barriers for development of markets for

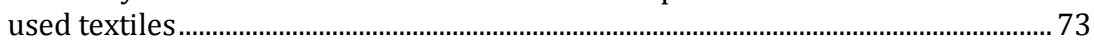

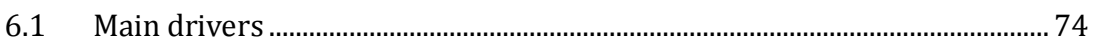

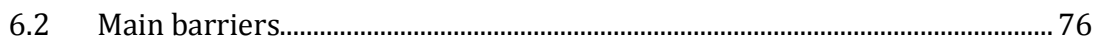

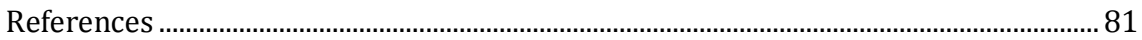


Collection and sorting systems

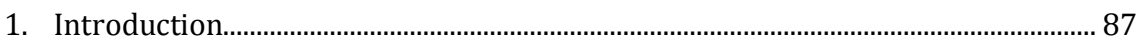

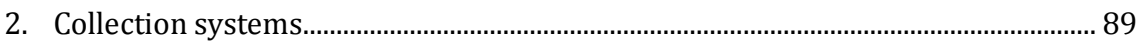

2.1 Operational collection systems ………………............................................. 89

2.2 Pilots and future possible collection systems ...............................................101

2.3 Summary of benefits and disadvantages for collection systems................108

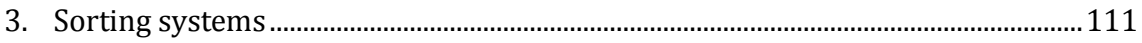

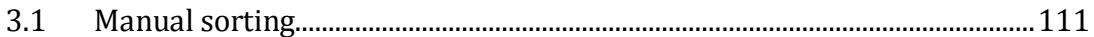

3.2 Semi-automated sorting .............................................................................113

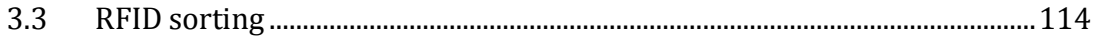

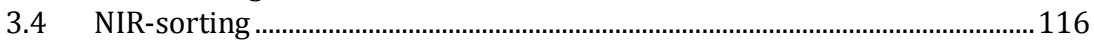

3.5 Summary of benefits and disadvantages for sorting systems....................117

4. Conclusions and recommendations......................................................................119

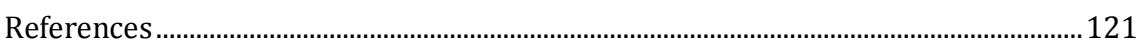

Technology review of sorting and recycling of textiles...................................................123

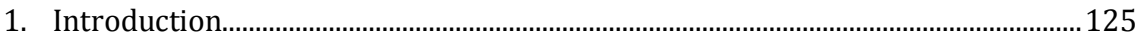

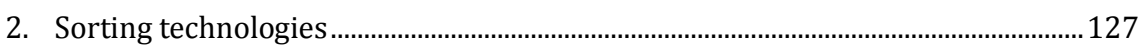

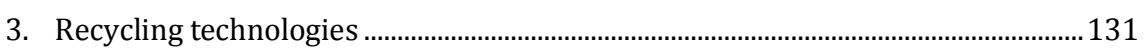

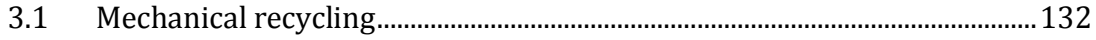

3.2 Chemical recycling.............................................................................................133

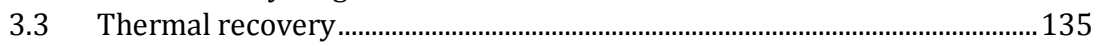

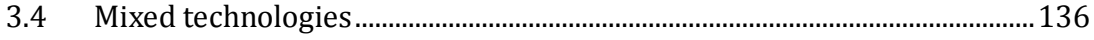

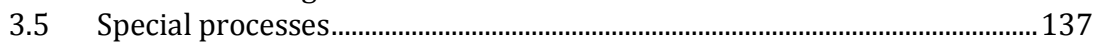

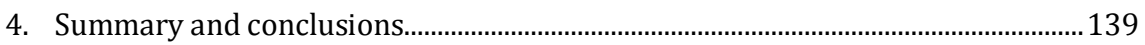

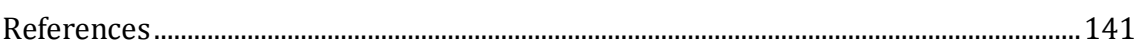




\section{Key messages}

Collection, sorting, reuse and recycling all have different aspects to be improved in the Nordic countries and some areas are further along than others. The main barriers related to low collection are partly due to unclear regulation for collecting organisations, the definition of waste and the non-existing high grade recycling possibilities which give recyclable textiles a very low value. There is also a lack of domestic recycling capacity which makes collection for recycling unattractive for collectors since incineration costs of textiles are considered high.

There are a large number of available collection systems and technologies both within the Nordic countries and abroad and have also in later years been tried alternative systems to increase the collection of textiles. A key difference between regular "waste collection" and collection of textiles, mainly for reuse, is the higher need for clean and dry collection.

Sorting technology for reuse is virtually non-existing and not well developed for sorting for recycling. Advanced NIR (Near Infra Red) sorting may come into play in the coming years, but only for sorting recyclable textile.

The most common recycling technology at present is mechanical recycling (shredding and similar). Current technology is, except for pure polyester recycling, limited to low grade recycling into insulation and carpet filling. Polyester recycling requires very clean flows of pure poliester textile. Emerging technologies such as Re:newcells technology for cotton recycling is promising but has significant development still to come. A Nordic investment in technology development could possibly create a new world leading recycling industry.

The key messages and findings presented in this report are part of the Nordic Prime Ministers' overall green growth initiative, The Nordic Region - leading in green growth. 



\section{Introduction}

\section{Background}

In recent years textile production and consumption have risen drastically in the Nordic region. To exemplify, the textile consumption in Sweden increased with $40 \%$ during the last 10 years and now amounts to $15 \mathrm{~kg}$ per capita, including clothes and home textiles only. The consumption levels are similar for all Nordic countries with Finland at $13.5 \mathrm{~kg}$ and Norway at $22 \mathrm{~kg}$ per capita. Most used textiles either end up in the back of the wardrobe, or in an incinerator, while only a small fraction is reused and recycled.

Collection of textiles in the Nordic countries is performed on a voluntary basis, mostly by charity organisations. Textiles are only collected for reuse and large volumes of both reusable and recyclable textiles end up in the residual waste. This represents a potential for increased collection volumes and increased reuse and recycling. There is a need to develop efficient systems that collect textiles both for reuse and recycling, in order to realise this potential.

Most textile sorting is performed in low cost countries, due to being labour intensive. An automated solution would be necessary for this activity to be performed in the Nordic region. This requires large volumes and a secure supply of textiles together with a demand from producers for the recyclable fraction. A recycling facility must not risk having a negative impact of current reuse of textiles. In order to find possible textile waste streams and best available recycling technology an international approach must be used investigating the markets for new and used textiles.

This project is one of six which constitute Resource Efficient Recycling of Plastic and Textile Waste, a project launched by the Nordic Waste Group (NWG) as part of the Nordic Prime Ministers' green growth initiative, The Nordic Region - leading in green growth. The initiative identifies eight priorities aimed at greening the Nordic economies, one of which is to develop innovative technologies and methods for waste treatment.

A Nordic strategy for collection, sorting, reuse and recycling of textiles is one of three projects to increase the reuse and recycling of textiles in the Nordic region. The other two are: The Nordic reuse and recycling commitment and An extended producer responsibility (EPR) system and new business models to increase reuse and recycling of textiles in the Nordic region. 
The aim of the project as stated in the tender from the Nordic waste group:

Develop a proposal for a common Nordic strategy for improving infrastructure for collection, sorting and reuse/recycling of textiles in the Nordic region that can also represent a competitive advantage for Nordic business within the textile sector. [...]

(Tender published by the Nordic waste group, April 2013)

\section{The project}

The project is carried out by a consortium with IVL Swedish Environmental Research Institute (Sweden), Copenhagen Resource Institute (Denmark), Ostfold Research (Norway), SYKE Finnish Environment Institute (Finland), Environice (Iceland) and University of Nordland (Norway). David Palm at IVL acts as project manager.

The work is performed in close connection with the Nordic waste group and Coordinator Yvonne Augustsson and also has a reference group connected to the project to ensure the outcome of the project. Related to this project are also two Nordic workshops organized by the Sustainable Fashion Academy on behalf of the Nordic Council of ministers.

The project runs from June 2013 to December 2014.

The reference group members are:

- Anna Bengtsson, Ragn-Sells, Sweden.

- Arnt-Willy Hjelle, Fretex, Norway.

- Dan Boding-Jensen, former at Vestforbrænding, Denmark.

- Elisabeth Dahlin, Swedish Red Cross, Sweden.

- Emma Enebog, Myrorna, Sweden.

- Erik Hove, Danish Red Cross, Denmark.

- Ingun Klepp Grimstad, SIFO, Norway.

- John Hansen, Teknologisk Institut, Denmark.

- Jon Nilsson-Djerf, Waste Management Sweden, Sweden.

- Kristiina Aalto, Konsumentforskningscentralen, Finland.

- Marja Pitkänen, VTT, Finland.

- Ólafur Kjartansson, Icelandic Recycling Fund, Iceland.

- Päivi Talvenmaa, Tampere University of Technology, Finland.

Some organisations have been represented also by other colleagues for part of the work. 


\section{Summary of the reports}

This report is the primary outcome from Part I of the project "Towards a Nordic textile strategy - Collection, sorting, reuse and recycling of textiles" initiated by the Nordic Waste Group (NAG). The report for Part 2 will be published in December 2014.

This report summarizes the work from the first year of the project and its three subreports covering various parts of the issue as basis for the work to be performed in 2014 .

The reports for 2013 are:

- International market survey.

- Collection and sorting systems.

- Technology review of sorting and recycling of textiles.

The findings presented in the three reports are part of the Nordic Prime Ministers' overall green growth initiative: The Nordic Region - leading in green growth. Read more in the web magazine Green Growth the Nordic Way at www.nordicway.org or at www.norden.org/greengrowth

\section{International market survey}

The first report gives an overview of the textile flows in the Nordic region and the market for collection, sorting, preparing for reuse and reselling of used textiles and waste management of textiles. It includes the legal and economic conditions for operation that depends on the actors' status as a charity, authority or private business. The report also gives insight into the European and global markets for used textiles and the drivers and barriers for market development.

Main drivers are that the prices for textiles collected in the Nordic region appears to be higher than the European average combined with a growth in demand for second hand clothing. This combined with the willingness to separate textiles from other waste create a basis for a reuse market. The increased levels of new textiles also create higher volumes available for trading which could create economy of scale. The increased level of political interest is also positive for the market. 
Main barriers are related to low collection partly due to unclear rules for collecting organisations and the definition of waste and the nonexisting high grade recycling possibilities which give recyclable textiles a very low value. There is also a lack of domestic recycling capacity which makes collection for recycling unattractive for collectors since incineration costs of textiles are high.

\section{Main conclusions}

- The prices for textiles collected on the Danish market appear to be relatively high compared to the European average. This is likely true also for the other Nordic countries.

- The Nordic countries have generally seen a growth in the demand for second-hand and vintage clothing.

- Making better use of used textiles both in an environmental and economic perspective has moved higher up the policy agenda in some Nordic countries. So far however, this has not resulted in much in the way of legislative change specific to textiles.

- In some Nordic countries there is lack of coherence on who has the responsibility for granting permission to collect textiles. This results in illegal textile containers, a lack of transparency of material flows and to some extent to a distorted market.

- The majority of the textiles collected by organisations in Nordic countries is exported for further sorting and subsequent handling in other European countries due to high wages in the Nordic countries.

- In a number of countries, high street chains face obstacles in donating faulty or returned textiles to charities due to the fact that they can't then reclaim VAT from donated unused textiles.

- Most recycling taking place in Europe is downcycling.

- Non-reusable textiles are still not being collected due to a lack of domestic market.

\section{Collection and sorting systems}

The second report is a collation of operational and pilot or future collection and sorting systems. The collection systems include both organizational and technical collection systems for all types of textile or sub fractions such as clothing or home textiles. A total of 19 systems are compared for collection flows, contamination levels, cost, suitability of collected textile and availability for the consumer. 
Four sorting systems are described: Manual sorting; semi-automated sorting, RFID sorting and NIR-sorting where the first two are operational and the latter two are experimental. Semi-automated sorting is the most common sorting at present and can be done in rather small scale. An important note is that none of the future sorting systems are capable of sorting reusable from non-reusable textiles.

\section{Main conclusions}

- There are a large number of available collection systems and considerably fewer sorting systems. Sorting for reuse will be manual sorting for the foreseeable future while sorting for recycling might become more automated.

- Collection systems with a capacity for large textile flows have in general a higher contamination levels in the collected textiles. This is likely due to little manual involvement in collection which makes collection cost efficient, but may cause issues later in the value chain.

- The system of a mandatory EPR fulfills most requirements for a collection system, likely because it combines several of the different collection systems in a joint effort. A mandatory EPR may however have a high risk of contaminations in the collection and can potentially have a high total cost for collection.

\section{Technology review of sorting and recycling technology}

The third report describes available and future technology for sorting and recycling. It gives a more in-depth view of the NIR-sorting as well as other possible sorting technology.

The main recycling paths of mechanical recycling; chemical recycling; thermal recovery and mixed technologies are elaborated with examples of possible recycling routes. Current technology is, except for pure polyester recycling, limited to low grade recycling into insulation and similar. Emerging technologies such as Re:newcells technology for cotton recycling is promising but has significant development still to come. A Nordic investment in technology development could possibly create a new world leading recycling industry. 


\section{Main conclusions}

- Large scale recycling available are mostly mechanical, with shredding into insulation as the main technique. Simple cutting into rags is also a common recycling. These have a limited environmental benefit since they represent a downcycling rather than a closed loop recycling process.

- In the Nordic countries it seems that the market for textile waste for recycling is almost inexistent, due to the lack of recycling technologies available.

- There are a few technologies, especially Re:newcell, that show promising possibilities in the future. The actual performance is though yet to be seen for these technologies with reference to losses, chemical- and energy use in full scale recycling.

- The Nordic region seems to have a possibility to advance in the recycling of textile, not only for its' own textile but for the European market. The focus should be on high quality end products with a market demand, to ensure both economic and environmental sustainable recycling processes. 


\section{Sammanfattning av rapporterna}

Denna rapport sammanfattar arbetet från projektets första år och dess tre delrapporter som tillsammans ger ett underlag för 2014 års arbete. Rapport för Del 2 kommer att publiceras när projektet är klart i december 2014.

2013 års rapporter är:

- En internationell marknadsöversikt.

- Insamlings och sorteringssystem.

- Teknologiöversikt över sortering och återvinning av textil.

Rapporternas resultat är en del av de nordiska statsministrarnas grön tillväxt initiativ, Norden - ledande i grön tillväxt. Läs mer i nättidningen Grön tillväxt i Norden Way of www.nordicway.org eller www.norden.org/ greengrowth

\section{En internationell marknadsöversikt}

Den första rapporten ger en översikt av textilflödena i Norden och marknaden för insamling, sortering, förberedelse för återanvändning och försäljning av av använd textil samt avfallshantering av textilavfall. Den innehåller de rättsliga och ekonomiska förutsättningar för verksamheten som beror på aktörernas status som välgörenhetsorganisationer, myndigheter eller privata verksamheter. Rapporten ger också inblick i de europeiska och globala marknaderna för använd textil och drivkrafter och hinder som påverkar marknadens utveckling.

De främsta drivkrafterna är att priserna för textilier som samlats in i Norden verkar vara högre än genomsnittet i Europa i kombination med en ökad efterfrågan på begagnade kläder. Detta i kombination med viljan att separera textilier från annat avfall skapar grunden för en återanvändningsmarknad. De ökade nivåerna av nya textilier skapar också högre volymer tillgängliga för handel som skulle kunna skapa stordriftsfördelar. Den ökade nivån av politiskt intresse är också positivt för marknaden.

De främsta hindren är relaterade till låga insamlingsnivåer delvis på grund av otydliga regler för insamlingsorganisationer, definitionen av avfall och frånvaron av höggradiga återvinningsmöjligheter som ger återvinningsbara textilier ett mycket lågt värde. Det finns också en brist på 
inhemsk återvinningskapacitet som gör att insamling för återvinning blir ointressant för insamlare då förbränningskostnaderna för textilier är hög.

\section{Slutsatser}

- Priserna för textilier som samlats in på den danska marknaden förefaller vara relativt höga jämfört med genomsnittet i Europa. Detta stämmer troligen även för övriga nordiska länder.

- De nordiska länderna har generellt sett en ökning i efterfrågan på second hand och vintage kläder.

- Bättre utnyttjande av använda textilier både ur miljömässigt och ekonomiskt perspektiv har flyttats högre upp på den politiska dagordningen i flera nordiska länder. Hittills har dock detta inte lett till någon större förändring i lagstiftning specifik för textilier.

- I vissa nordiska länder finns det brist på samstämmighet om vem som har ansvaret för att bevilja tillstånd att samla in textil. Detta resulterar i olagliga textilbehållare, en brist på insyn i materialflöden och till viss del till en snedvriden marknad.

- Majoriteten av de textilier som samlats in av organisationer i Norden exporteras för vidare sortering och efterföljande hantering i andra europeiska länder på grund av höga löner i de nordiska länderna.

- I ett antal länder möter butikskedjor hinder i att donera felaktig eller returnerad textil till välgörenhetsorganisationer på grund av det faktum att de då inte kan få tillbaka moms från donerad textil.

- Den mesta återvinningen som äger rum i Europa är downcycling.

- Icke-återanvändbara textilier samlas fortfarande inte på grund av en bristande inhemsk marknad.

\section{Insamling och sorteringssystem}

Den andra rapporten är en sammanställning av operativa och pilot- eller framtida system för insamling och sortering. Systemen för insamling omfattar både organisatoriska och tekniska insamlingssystem för alla typer av textil- eller underfraktioner, såsom kläder eller hemtextilier. Totalt 19 system jämförs för insamlingsflöden, föroreningsnivåer, kostnad, lämplig insamlad textil och lätt-tillgänglighet för konsumenten.

Fyra sorteringssystem beskrivs: Manuell sortering, halvautomatisk sortering, RFID-sortering och NIR-sortering där de två första är operativa och de två sistnämnda är i pilotskala. Halvautomatiserad sortering är den vanligaste sortering för närvarande och kan utföras i relativt liten skala. 
En viktig notering är att ingen av de framtida sorteringssystemen är kapabla att sortera återanvändbara från icke-återanvändbara textilier.

\section{Slutsatser}

- Det finns ett stort antal tillgängliga insamlingssystem och betydligt färre sorteringssystem. Sortering för återanvändning kommer att vara manuell sortering för överskådlig framtid samtidigt som sortering för återvinning kan komma att bli mer automatiserad.

- Insamling system med kapacitet för stora textilflöden har generellt högre föroreningsnivåer i den insamlade textilen. Detta beror sannolikt på låg manuell hantering i insamlingen som gör insamlingen kostnadseffektiv, men som kan orsaka problem senare i värdekedjan.

- Systemet med ett obligatoriskt producentansvar uppfyller de flesta krav på ett insamlingssystem, troligen eftersom det kombinerar flera av de olika insamlingssystemen i en gemensam insats. Ett obligatoriskt producentansvar kan dock ha en högre risk för föroreningar i insamlingen och kan möjligen ha en hög totalkostnad för insamling.

\section{Teknologiöversikt över sortering och återvinning av textil}

Den tredje rapporten beskriver tillgängliga och framtida tekniker för sortering och återvinning. Det ger en fördjupad bild av NIR-sortering samt även andra möjliga sorteringstekniker.

De främsta återvinningsmöjligheterna med mekanisk återvinning, kemisk återvinning, energiåtervinning och kombinerade tekniker gås igenom med exempel på möjliga återvinningsvägar. Dagens teknik är, med undantag för ren polyesteråtervinning, begränsad till låggradig återvinning till isolering och liknande. Ny teknik såsom Re:newcells teknik för återvinning av bomull är lovande men har betydande utveckling kvar. En nordisk satsning på teknisk utveckling inom området skulle kunna skapa en ny världsledande återvinningsindustri.

\section{Slutsatser}

- Tillgänglig storskalig återvinning är mestadels mekanisk, med rivning till isolering som den vanligaste tekniken. Enkel tillklippning av trasor är också en vanlig återvinning. Dessa har en begränsad miljönytta eftersom de representerar en downcycling snarare än en closed loop återvinningsprocess.

- I Norden förefaller marknaden för textilavfall för återvinning vara nästan obefintlig, på grund av bristen på bra återvinningsteknik. 
- Det finns några tekniker, speciellt Re:newcell, som visar lovande möjligheter för framtiden. Den faktiska prestandan för denna teknik är dock ännu oklar med avseende på förluster, kemikalie- och energianvändning vid fullskalig återvinning.

- Norden kan ha en möjlighet att ta täten för återvinning av textil, inte bara för de egna textilmängderna utan även för den europeiska marknaden. Fokus bör ligga på högkvalitativa slutprodukter med en tydlig efterfrågan på marknaden, för att säkerställa både ekonomiskt och miljömässigt hållbara återvinningsprocesser. 


\section{International market survey}

By David Watson \& Nikola Kiørboe, Maria Elander, Hanna Salmenperä, Kari-Anne Lyng, Stefán Gíslason 



\section{Introduction and aim}

There are a large number of public and private actors working within the areas of collection, sorting, preparation for reuse and reselling of used textiles and involved in textile waste management in Nordic countries. Each actor operates according to its own business model and these business models vary widely from actor to actor. The legal and economic conditions under which they operate can also vary depending on their status as businesses, charities, public authorities etc. While the legal conditions tend to be country specific the economic market conditions are increasingly determined at the European and global level.

This document presents an overview of volumes of used textile flows from households and business and the key market and legal conditions under which actors involved in the collection, reuse and resale, recycling and other waste management of used textiles operate. The report considers clothing and household textiles and similar textiles from public and private organisations i.e. hospital linen, uniforms etc. Carpets are not included, nor are technical textiles. All figures on textile flows are to some extent estimations since the measurement of flows and statistics related to textiles are not very detailed.

The document gives an overview of flows of textiles and of framework conditions under which the collectors, sorters and recyclers operate in the individual Nordic countries, including an overview of the European and global market for their products. This includes consideration of the drivers for and barriers to further collection, reuse and recycling. The findings in the individual countries are compared and contrasted to give a picture of conditions in the Nordic region as a whole.

Information has been gathered via literature surveys, knowledge of the task partners gained during other projects, and through consultation with key actors both in Nordic countries (including members of the Reference Group).

International market survey is one of three sub-reports that summarize the work from the first year of the Nordic Council of Ministers project $A$ Nordic strategy for collection, sorting, reuse and recycling of textiles.

The project is one of six that constitute Resource Efficient Recycling of Plastic and Textile Waste, which was launched by the Nordic Waste Group (NWG) as part of the Nordic Prime Ministers' green growth initia- 
tive, The Nordic Region - leading in green growth. Read more in the web magazine Green Growth the Nordic Way at www.nordicway.org, or at www.norden.org/greengrowth 


\section{Overview of textile flows in the Nordic region}

\subsection{Denmark}

About 89,000 tonnes, corresponding to $16 \mathrm{~kg}$ per capita of new clothing and household textiles, are put on the Danish market each year for consumption. This amount provides an indication of the amount of used textiles being generated each year if constant conditions are assumed. Approximately 41,000 tonnes are collected separately by various charity and private organisations each year. Of the separately collected textiles approximately 23,000 tonnes are exported for reuse and recycling and 12,000 tonnes are reused (with a small amount of recycling) within Denmark. The remaining 6,000 tonnes is incinerated.

The fate of the estimated 48,000 tonnes, the gap between new textiles put on the market each year and what is separately collected following use, can be roughly estimated using waste survey data supported by assumptions. These assumptions can be viewed in Danish EPA (forthcoming).

A summary of the flow of these textiles is presented in Figure 1. A more detailed breakdown of volumes collected, methods of collection and the market for the collected textiles are presented in Chapter 3. 
Figure 1 Flow and destination of textiles in Denmark in 2010

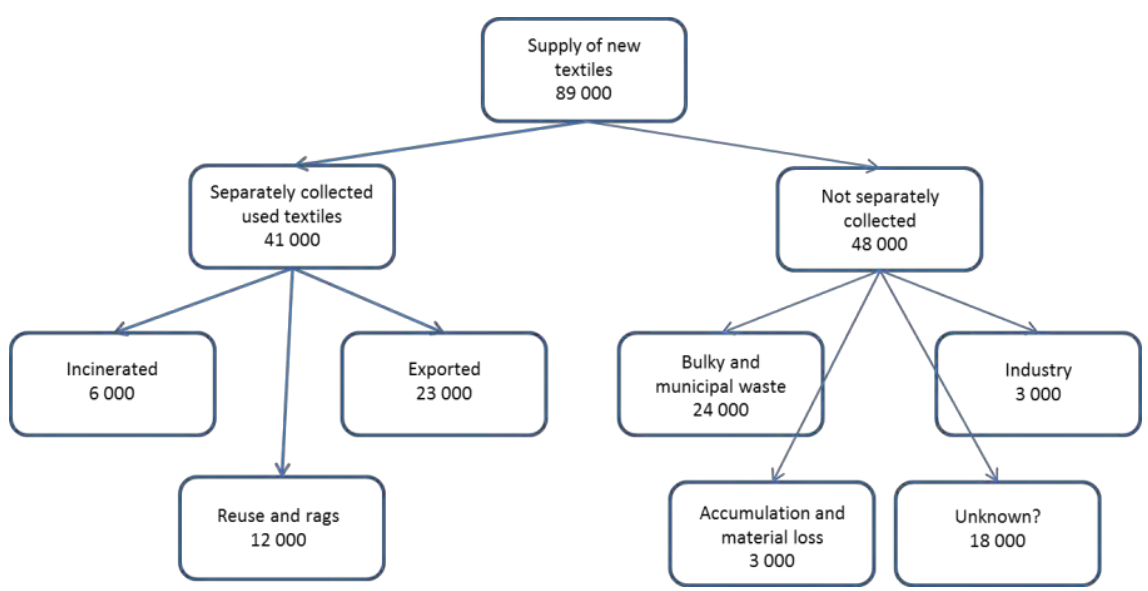

Ton - in rounded numbers. Source: own making based on updated data from Tojo et al. (2012) and Danish EPA (forthcoming).

\subsection{Finland}

The net annual inflow of new textiles in Finland is about 71,000 tonnes per year. This corresponds to $13.5 \mathrm{~kg}$ per person. Most of the textiles are imported (76,500 tonnes), whereas domestic production is low (2,400 tonnes). The annual exports are approximately 8,000 tonnes for new clothes and 6,250 tonnes for second-hand clothes and rags (Tojo et al., 2012).

Approximately 25,000 tonnes of used textiles are collected annually, i.e. about $4.7 \mathrm{~kg}$ per inhabitant. Of this, 7,000 tonnes (28\%) are sold for reuse in Finland and around 8,500 tonnes (34\%) for recycling in Finland. As mentioned above 6,200 tonnes of second-hand clothes and rags are exported. The remaining 3,300 tonnes (13\%) are considered as unusable waste and are sent for incineration or landfill (Tojo et al., 2012). These figures are estimates and the division between re-use, recycling, and waste is not exactly known. The flows are given in Figure 2. No information is available on the fate of the 46,000 tones which aren't collected separately. More detail of individual operators is given in section 3.2. 
Figure 2 Flow and destination of textiles in Finland 2010 (tonnes)

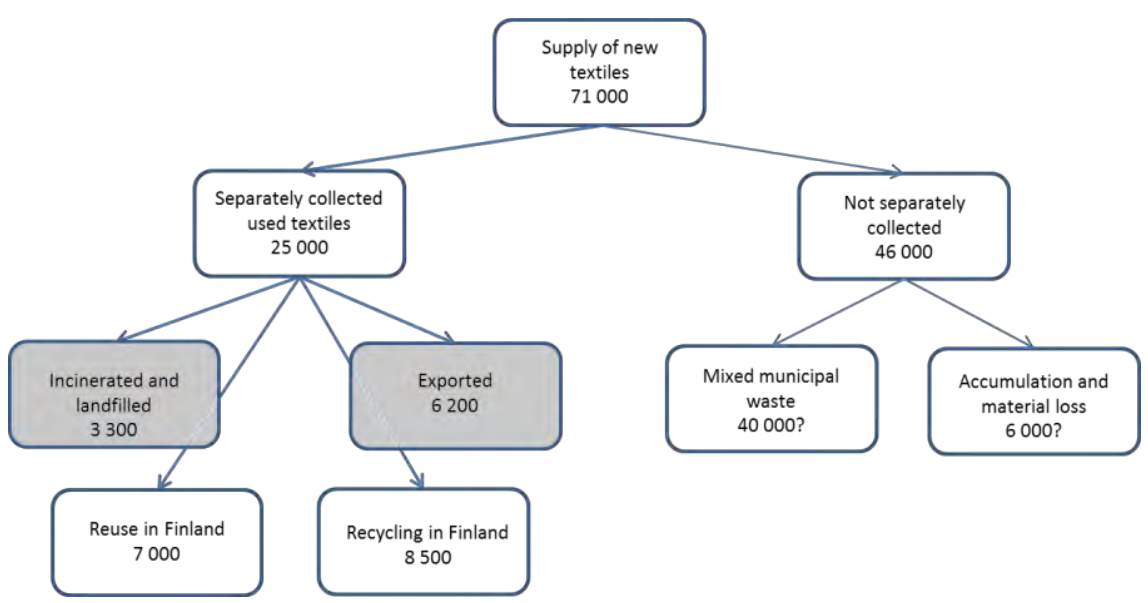

Source: own making based on updated data from Tojo et al. 2012.

\subsection{Iceland}

From the information collected by Statistics Iceland, it is not possible to estimate the exact amount of textile produced for the domestic market. Assuming that around half of the domestic production is exported, it can be estimated that some 1,000 tonnes of the production is put on the domestic market. Import of textiles amounts to 3,800 tonnes (2012), giving a total estimate of 4,800 tonnes ( $15 \mathrm{~kg}$ per capita) of clothing and household textiles are put on the Icelandic market annually.

Approximately 1,400 tonnes (or $4.5 \mathrm{~kg}$ per capita) of used textiles (and shoes) are separately collected by organisations, of which 1,350 tonnes of used textiles are exported for sorting and further handling in Germany and the Netherlands. 50 tonnes are sold for re-use on the domestic market.

The majority of the remainder of textiles put on the market are assumed to end in mixed waste streams. Almost all (98.8\%) of the waste destined for final disposal in Iceland is landfilled. ${ }^{1}$ According to information from Sorpa waste management company textiles make up approximately $2.5 \%$ of total unsorted household waste. ${ }^{2}$ In 2011 a total of

${ }^{1}$ Statistics Iceland (2013): Statistical Yearbook of Iceland 2013. http://issuu.com/hagstofa/docs/landshagir2013?e=7193385/5220768. (Pg. 43).

2 Personal information received from Sorpa waste management company. 
127,000 tonnes of waste was sent to disposal, including mixed household waste and mixed non-household production waste. Assuming the latter also contains around 2.5\% textiles, 3.200 tonnes (or $10 \mathrm{~kg}$ per capita) of textile waste is landfilled annually.

As assumed above, some $15 \mathrm{~kg}$ per capita are put on the market annually, $10 \mathrm{~kg}$ are landfilled and $4.5 \mathrm{~kg}$ are collected for reuse or recycling. The remaining $0.5 \mathrm{~kg}$ (200 tonnes) is assumed to accumulate in closets and attics.

The flows are given in Figure 3. More detail of individual operators is given in section 3.3. It should be underlined that many of the figures above are based on assumptions. In addition a perfect balance in "input" and "output" flows should not be expected. The amount of new textiles put on the market is increasing, which means that the amount of used textiles being generated is likely to be lower than the amount of new textiles put on the market in any given year.

Figure 3 Flow and destination of textiles in Iceland 2012 (tonnes)

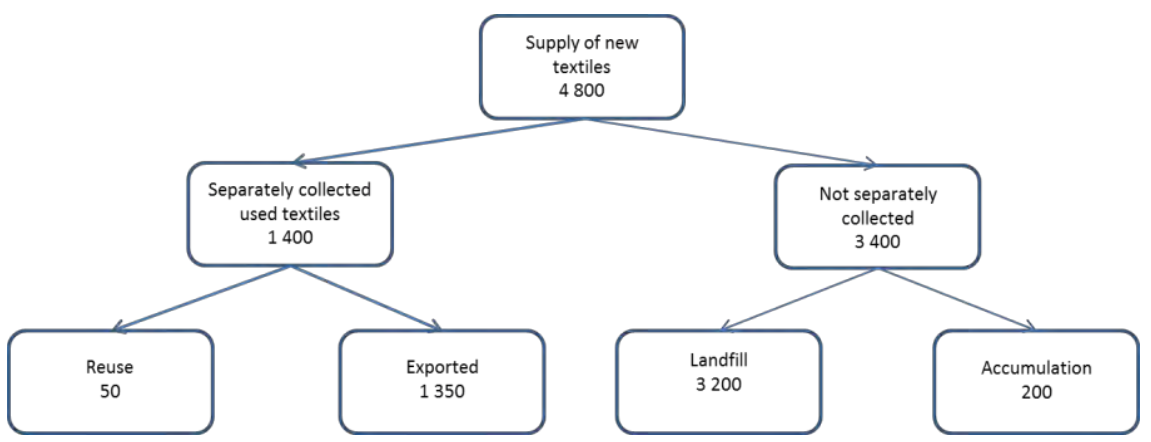

Source: own making based on various data sources and assumptions.

\subsection{Norway}

Due to limited production of clothing in Norway, the net annual amount of clothing put on the marked is assumed to correspond to the amount of imported clothes, which is about 72,000 tonnes per year (Statistics Norway, 2013). There is no information available on other household textiles put on the market each year.

According to Statistics Norway the total amount of textile waste was 113,000 tonnes in 2011 , which is about $22 \mathrm{~kg}$ per capita per year. However, these numbers include all sectors such as textile waste from industry and not just households. It has been estimated that approximately 48,000 tonnes of used textiles were generated by households in 2011 
(Statistics Norway, 2013) and that this has more than doubled over the last 20 years (Norwegian Ministry of Environment, 2013).

About 23,000 tonnes of the total used textiles are collected separately by charities and other organisations. According to annual reports from the charities this approximately 1,000 tonnes is separated for reuse in Norway, approximately 21,000 tonnes of mixed used textiles are exported for reuse and recycling in other countries (Laitala et al., 2012) and the remaining approx. 1,000 tonnes of low quality textiles are incinerated.

It is assumed that the majority of the remaining used textiles generated each year (approx. 27,000 tonnes) end in mixed municipal waste and is mostly incinerated with a small share going to landfill. There are no longer any textile recycling facilities in Norway (see under 3.4 later). Laitala et al. (2012) estimates that $25-35 \%$ of the used textiles that ends in the mixed municipal waste each year could have been reused.

There is a large gap between the new clothing put on the market and the estimates of used textiles that are either separately collected or end in mixed municipal waste. When the sold new household textiles put on the market are added into the equation, the gap grows even larger. Some of this gap can be accounted for by accumulation in household lofts and wardrobes. In addition, if quantities of new textiles put on the market each year are growing, then one would expect a lower generation of used textiles than that put on the market in any given year. Finally, the estimations of textiles in mixed municipal waste are likely to be based on some limited sampling surveys and therefore associated with significant uncertainties. 
Figure 4 Flow and destination of textiles in Norway (tonnes)

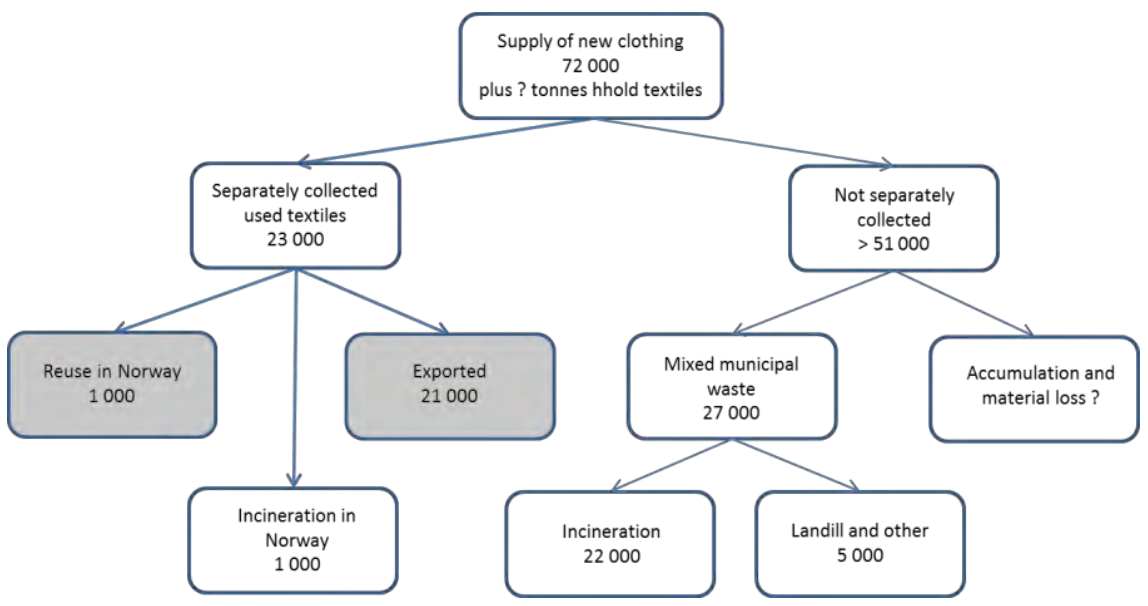

Source: own making based on National Statistics, Laitala et al. 2012 and annual reports from collectors.

\subsection{Sweden}

In 2011 the SMED consortium mapped textile flows in Sweden and included clothing and home textiles (e.g. curtains, bed linen, blankets) but not shoes or furniture (e.g. sofas)(Carlsson et al., 2011). Figures on textile consumption are from 2008, figures on textile in mixed household waste are based on 57 pick analyses performed during 2008-2010 and figures from reuse are from the ten charities in the branch organisation Ideell Second Hand and Humana during 2008. 
Figure 5 Swedish textile flows per capita

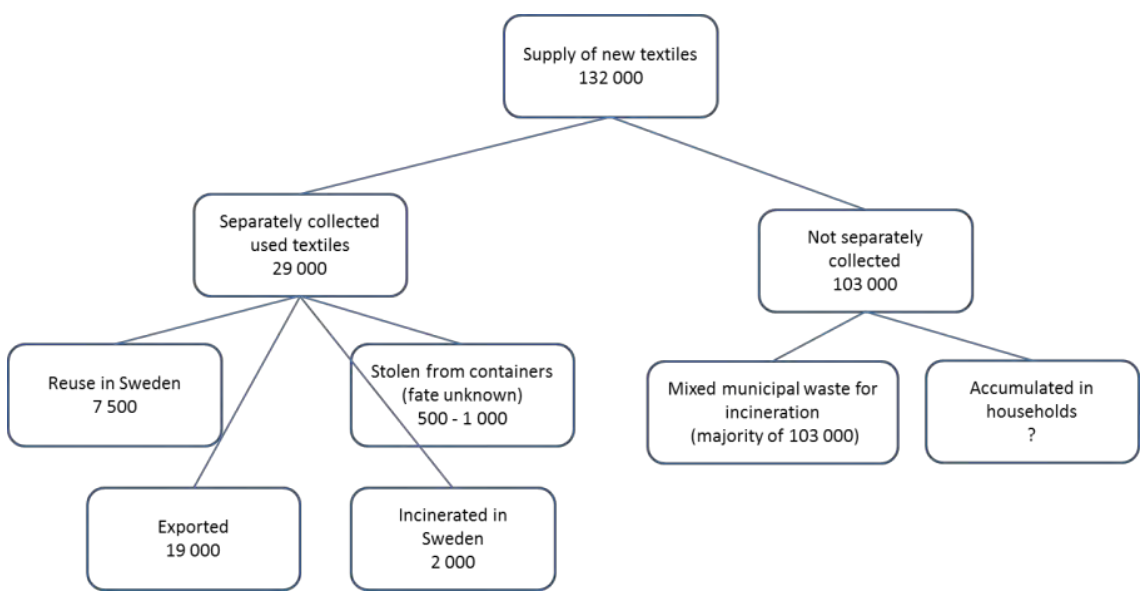

(adapted from Carlsson et al., 2011).

Sales of new clothing and household textiles totalled 132,000 tonnes in 2011 of which 95,000 tonnes was clothing and 37,000 tonnes was home textile. This corresponds to about $15 \mathrm{~kg}$ per person per year (SMED, 2011). Trends show that the consumption of textiles is increasing. This amount provides an indication of the amount of used textiles being generated each year if constant conditions are assumed.

About 20\% was collected by charities; more than $50 \%$ was thrown in mixed waste and the remaining $30 \%$ is likely a mix of household storage and discarding at recycling centres. A recent, not yet published study by the municipality of Stockholm shows that the textile flow at recycling centres is significant (Personne 2013).

Approximately 7,500 tonnes of the used textiles collected by charitable organisations is sold for reuse in Sweden (personal communication with Ideell Second Hand) with 19,000 tonnes exported for reuse and/or recycling in other countries (Tojo et al., 2012; Enebog, 2013; Rosinski, 2013). Approximately 800 tonnes is stolen from containers and the remainder is incinerated in Sweden. .

The fate of the estimated 103,000 tonnes gap between new textiles put on the market each year and what is separately collected following use, is not known but the majority is assumed to end in mixed household waste ending in incineration though some will also be accumulated in households and not disposed of.

Figure 5 show the Swedish textile flows adapt. The net inflow is as assumed as the same as the net import since domestic production is very small. A summary of the flow of these textiles is presented in Figure 5. A 
more detailed breakdown of volumes collected, methods of collection and the market for the collected textiles are presented in Chapter 3. 


\section{The Nordic market for used textiles and textile waste for recycling}

\subsection{Denmark}

\subsubsection{General overview of the market conditions}

The collection of used textiles is dominated by four large collectors: the charitable organisations Salvation Army (7,500 tonnes/yr.), Danish Red Cross (6,000 tonnes/yr.), Danchurch Social (5,000 tonnes/yr.) and one private actor, Trasborg (7,000 tonnes/yr.). There are also two smaller but still noteworthy collectors UFF (1,700 tonnes/yr.) and Danmission (1,000 tonnes/yr.).

Together with these organisations there is a large number of smaller actors (it is estimated that there are around 25 actors in total) who make up the remaining $40 \%$ of the Danish collection market. Thus the Danish collection market is considerably more diverse and competitive than in the other Nordic countries.

There are no official requirements for who may collect textiles in Denmark, but it is a requirement that the collector shows transparency with respect to whom they are and how donations are being used.

Used textiles are most commonly collected via containers or over the counter in the organisations shops. If a collector is to collect via containers in either a public space or at a waste recycling centre, they need to obtain permission from the municipality. Therefore, the municipalities are crucial actors in the market. Another option is to set up containers on private land like e.g. next to a supermarket, in which case the collector needs permission from the landowner.

A few brands have also begun collecting textiles via in-store drop-off boxes. This is typically executed as cooperation between the brand and a 
professional collector such as I:CO (agreements between collection companies and high-street retailers are described in more detail under a separate Nordic Council project. ${ }^{3}$ Finally, luxury second hand stores have a marginal, but growing share in the market for used textiles. They act as middlemen in customer-to-customer sales of high quality used clothing in exchange for a commission (usually around 50\%). If the clothes are not sold they are returned to the original owner.

Collectors can sort collected textiles themselves to a coarse or fine degree and then sell the various fractions via their own shops or for export, or they can sell the collected textiles unsorted.

Danchurch Social collects textiles exclusively across the counter only for resale in Denmark. Charities are eligible to sell textiles second hand without paying VAT, as long as they use profits for charitable activities and do not employ any paid personnel (Momsloven 2013). The so-called luxury second-hand retailers have to pay the output VAT, but since they can't refund any input VAT (all clothing is taken in commission for the customers), they face some difficult market conditions (Danish EPA 2013a). ${ }^{4}$

The remaining large organisations collect using containers as well as (in some cases) across the counter and find that a significant proportion of textiles deposited in containers are not suitable for reuse in Denmark. Some of the larger Danish collectors of textiles have cooperation agreements with European operators who buy the used textiles and then sort them and sell them on for either reuse or recycling depending on the quality. However, the Red Cross and Trasborg carry out detailed level of sorting themselves and UFF export their collected textiles to Humana's owned sorting plants in the Baltic countries. ${ }^{5}$

Most collected textiles by the larger organisations with containers, are exported for reuse or recycling in the European market. A smaller share (typically 10\%) is of sufficient quality for reuse in Denmark and another fraction is also sent for waste treatment (incineration). There is negligible recycling of textiles waste in Denmark.

Used textiles can be sold as many different categories according to level of sorting, quality, fibre and so on. A buyer can thus take a batch of unsorted textiles, a batch of semi-sorted textiles of which textiles suitable

\footnotetext{
3 See Background Report under Nordic Council project "The Nordic Textile Reuse and Recycling Commitment". 4 These shops are however eligible to make use of the so-called Brugtmomsordning (used VAT agreement), which means that when a used item is sold, the VAT is only calculated on basis of the profit, rather than the full price of the good (SKAT 2013).

${ }^{5}$ Humana is the umbrella organisation for UFF related organisations globally.
} 
for Danish reuse has been sorted out, or batches of sorted textiles such as woollen winter coats, cotton children's clothes etc., depending on the specific agreement. In general the price of used textiles is dependent on the quality of the textiles within a given fraction and on the degree to which it has been sorted.

\section{Export prices}

There are no easily accessible listings of Danish prices for used textiles, but some estimates have been obtained. The estimates are based on personal communication with the main collectors in Denmark.

Prices for exported textiles collected in Denmark are estimated to range between EUR $0.45 / \mathrm{kg}$ and up to more than EUR $4 / \mathrm{kg}$. The lowest prices are paid for exported textiles of which the best part (usually around 10\%) has been removed. The higher prices are paid for the $10 \%$ which are suitable for resell in Nordic countries (Hove 2013; RønnSimonsen 2013; Pihl 2013). Used textiles collected in Denmark are typically of higher quality than the average on the European market and receive a higher price than European averages. This may be due to the relatively wealth of Danish consumers who thus buy and dispose of better quality textiles (Dantextil 2013). The final fate of textiles exported from Denmark is unknown but it is assumed that a higher percentage can be reused than is typically on the European market.

\section{Prices for waste treatment}

An important factor in the market for used textiles is the prices for waste treatment. A company or organisation which wishes to use the municipal waste centres, must register to one in the municipality in which they are located. If the organisation's annual turnover is less than DKK 300,000 and the company has less than two employees they can be exempted from paying a waste fee for textiles fractions which the organisation can't or doesn't wish to sell. Charity organisations specifically are also exempted if they have a maximum of one paid employee (Affaldsbekendtgørelsen), which is however rarely the case. In all other cases collectors of used textiles have to pay the fee for the textiles which they discard.

The fees vary from municipality to municipality but should only cover the costs of handling the waste and not bring in a surplus (Miljøbeskyttelsesloven). ${ }^{6}$ The waste fee has been criticised for amongst other issues

\footnotetext{
${ }^{6}$ More specifically the fees are set by the waste treatment plants to which several municipalities can be connected.
} 
varying significantly across the country. Annual prices range from around DKK 300 up to almost DKK 2,400 per year, with a national average of DKK 870/year for the same type of company (Hansen 2011).

The larger charity organisations which collect textiles have in most cases been able to negotiate with the municipalities an exemption from this fee. Smaller collectors might, however, not have the resources to negotiate with the municipalities, and are therefore obliged to pay this fee as part of their activities.

\subsubsection{Specific drivers for market development}

The Danish market for used textiles is flourishing, reasonably lucrative and thus also competitive. There are many actors in the market, and existing actors are experiencing growth while new players enter the market in an attempt to make profits. The prices for textiles collected in the Danish market appear to be relatively high compared to the European average.

The drivers for this market are firstly an increase in the amounts of used textiles. The increasing demand for cheap fast fashion has led to an increasing potential supply of used textiles. Many consumer segments buy and dispose of textiles relatively often, and if these textiles are handed over to collectors who manage the textiles efficiently there will be a large supply of used textiles. The only challenge in this respect is that these textiles might be more suitable for recycling rather than reuse, due to reducing quality of the originally purchased textiles. In general, fast fashion trend is a strong driver for the supply of used textiles. On the other hand the fast fashion trend with cheap prices potentially reduces the Danish demand for reused clothing, increasing the importance of the export market for used textiles.

A further potential driver to the market has been the growth in the demand for second hand clothing along with other second hand items possibly partly catalysed by the economic slowdown beginning in 2008 but reinforced by a perception that reuse and vintage is fashionable (Skov et al., 2011). The second hand market has increased in Denmark in recent years, with Red Cross's sales increasing by 20\% between 2011 and 2012 (Dansk Mode og Tekstil 2012; Søndergaard, B. 2012). A 34\% growth in sales in charity shops over the same period in the UK has been linked to reductions in income due to the crisis (Ward, V. 2012). On the other hand, in both countries the supply of used clothing to second hand shops is reported to have decreased, due perhaps to increased private sale of used clothing and a lower willingness to get rid of clothes that citizens may have a use for later. 


\subsubsection{Specific barriers to market development}

\section{Setting up of containers}

The Danish waste legislation states that it is the municipalities who have an obligation, and thus also the right, to handle its citizens' waste. Further the municipalities have the power to decide on who may set up containers at their recycling centres and in public spaces. In general only organisations with a charitable use of its profit are allowed to set up containers in public spaces. Private collectors in practice are excluded from the market unless they team up with a charitable organisation.

Even where containers are to be set up on private land, for example in a supermarket car park, permission is still required from the municipality in the case that collection of used textiles is perceived as a waste collection activity. The municipality has the overall power to decide whether or not collection of used textiles represents waste but are advised by the Danish EPA that collection by charitable organisations should not be considered as waste collection (Danish EPA 2013b). This infers that collection by private organisations does represent waste collection and therefore requires special permission from municipalities. Why the distinction has been made between charitable and noncharitable organisations in the guidelines is not clear according to Dakofa (Inge Werther pers. comm. 2013).

It is therefore of general frustration to the private actors, that charity organisations have advantages in the market compared to them: Firstly, charity organisations are exempt from paying VAT while private collectors must operate under "normal" business conditions and secondly, charity organisations are given preferential treatment in that they are the only ones allowed by the municipalities to set up collection containers. The fact that a private collector will have to team up with a charity organisation in order to collect used textiles is a significant barrier to entering the market.

The charity organisations on the other hand, express frustration about private actors entering the market in order to make a profit. The charity organisations worry that the competition from private actors will reduce the collections of used textiles for raising money for charitable social projects in Denmark and further afield.

\section{Lack of a recycling market}

At present most collectors only receives textiles (and most commonly only clothes) which are suitable for reuse. This is due to collectors making it clear on containers that they do not wish to receive textiles not suitable for reuse, in part due to a lack of recycling facilities in Denmark. 
Textiles which are not suitable for reuse but which would be suitable for recycling are usually disposed of in households' residual waste and hereafter sent for waste treatment which in Denmark is primarily incineration with energy recovery. This is a significant lost resource.

A broadening of the textiles accepted by collectors would firstly require that there was a market for textiles for recycling and secondly an increased level of professionalization and market knowledge amongst the collectors. This would mean that they were to sort more textiles and/or operate more closely with buyers in/for the European/international market.

\section{The classification as waste}

The fact that used textiles are normally defined as waste is also a barrier to the market for reuse and recycling. One exception that has already been mentioned is used textiles collected by charity organisations which have undergone some sorting and are intended for reuse. The second exception are rags that are recycled as part of a closed system between the producer and the recycling facility.

All used textiles collected by non-charitable organisations, e.g. Trasborg and I:CO, and all sorted fractions by any organisation which are sent on for recycling are considered to be waste and thus by law are the responsibility and the property of the municipalities. If used textiles were reclassified as a product they could be traded more easily. It is expected that under these circumstances a large number of actors would enter the market and start competing for the available used textiles (Dantextil 2013).

\section{Wages}

The general level of wages also seems to be a common challenge, especially in connection with the sorting, which is why it is often outsourced to eastern European countries. Several collectors in the Danish market have expressed that the only reason for them not to engage in more professional/permanent staff for sorting is due to the high wages in the country. When collectors sort in Denmark it is often through use of volunteers or relatively poorly trained staff which means that the textiles might not be explored fully according to the prices in the market and/or according to the waste hierarchy. 


\section{Level of professionalism}

One additional challenge is that the market is also partly run by un- or semi-professional actors who operate with only partial knowledge of the market for collected textiles. This can have many distorting consequences such as textiles not being handled according to the waste hierarchy, ${ }^{7}$ which will also result in that "full" profits not being realised. As mentioned at the BIR World Recycling Convention in the fall of 2012 "people are entering the industry because they think they will make a profit, but often do not have a clue of how much the clothing and textiles are worth" (BIR 2012).

\subsection{Finland}

\subsubsection{General overview of the market conditions}

The collection of used textiles in Finland is dominated by four charity organisations (UFF, Red Cross, Fida International and Salvation Army). These operators collect used textiles mainly through containers located in larger population centres and/or next to local waste collection sites for other source separated waste. Permission for positioning a collection container needs to be asked from the landowner (i.e. municipality, retail group). Stealing of textile waste from the containers is not common in Finland, but does take place occasionally. This minor problem is tackled by introducing more protective container types.

A smaller amount of used textiles is collected either through second hand shops held by the charity organizations or through pickup services provided by the organizations. Additionally, some municipal waste management companies and municipalities collect used textiles in their recycling centres and a handful of privately owned companies collect textiles both from consumers and industry to be used as input in their processes (Hinkkala 2011).

The largest organisation in volume, UFF, operates in the area of 200 municipalities in Finland and collects 9,150 tonnes of used textiles annually. The collection is organized through an extensive container collection network. According to UFF, their approximately 2,000 containers

\footnotetext{
${ }^{7}$ If the market was functioning perfectly, the textiles would be handled according to the waste hierarchy since the price at this point in time follows this categorisation. This might however change over time, as e.g. recycling technology improves.
} 
can be reached by $60 \%$ of the population. Municipalities' recycling centres and Red Cross also offer used textiles to UFF when they have oversupply. Textiles emptied from the collection containers are delivered to the sorting centre where two-thirds are exported unsorted for wholesale to Humana organisations in other countries and private companies in Eastern Europe and Russia. The remaining third is sorted into clothes to be sold into fractions for export to Africa, domestic sales in UFF's own shops, and finally into rags and waste.

Domestic sales in UFF's 16 second-hand shops account for only $6 \%$ of the collected textiles, but are the main income source of the organization. UFF has one sorting centre in Southern Finland, where it employs 30 persons on a regular basis. Additionally, 70 persons work in management, logistics and in the retail stores of the organization (Hinkkala 2011, UFF 2012).

Red Cross collects used textiles through their pickup service, containers and second-hand shops. Donations of textiles amount to 7,000 tonnes per year. The organization has two sorting centres in Finland. In sorting, Red Cross emphasizes that only clothes with good quality are meant for international charity. The organization has expressed a shortage of mens' and boys' clothes of good quality. Also bed linen and blankets are in deficit. Of the income of Red Cross, $25 \%$ is used for their textile reuse activities (Hinkkala 2011.)

Fida International has 30 second-hand shops around Finland. Fida co-operates with the Helsinki Region Environmental Services Authority and UFF. In Southern Finland Fida has 60-70 containers and one sorting centre. Fida manages about 1,600-2,000 tonnes of used clothes and textiles (Hinkkala 2011).

The Salvation Army has 30 second-hand shops around Finland where used textiles are received and sold. Textiles are collected through containers, and the donated clothes and textiles are sorted in the organization's four regional centres. Part of the sorted clothes goes directly to Estonia and Poland for reuse. Cotton, e.g. T-shirts, is delivered to industrial use (Hinkkala 2011).

In total, the four mentioned charity organizations and other collectors have been estimated to collect 25,000 tonnes (or $4.7 \mathrm{~kg}$ per capita) of used textiles annually. Of the overall 25,000 tonnes, 7,000 tonnes (28\%) are sold in Finland for reuse and around 8,500 tonnes (34\%) are recycled in Finland. About 6,000 tonnes of second-hand clothes and rags are exported while 3,300 tonnes (13\%), are considered as unusable waste (Tojo et al., 2012). These figures are estimates and the division between re-use, recycling, and waste is not exactly known and can vary 
between operators. For example, as noted above, UFF reports that only $6 \%$ of the total 9,150 tonnes of collected textiles are sold in their retail shops in Finland, 73\% is exported to wholesale buyers for reuse and recycling, and $8 \%$ is sent to Africa for reuse. The rest, 13\%, comprises rags and textile waste. Rags can be recycled to some extent, the rest is incinerated (UFF 2012).

With 25,000 tonnes of used textiles estimated to be collected yearly, and 71;000 tonnes of new textiles put on the market up to 46,000 tonnes $(65 \%)$ of new textiles purchased in Finland each year remain unaccounted for. This implies a large potential for increasing the supply of used textiles in Finland by $100-200 \%$ for eventual reuse and recycling. Some of the 46,000 tonnes is likely to be accumulated in households while a large part of the remainder most likely ends up in ordinary municipal mixed waste. According to the estimations, $73 \%$ of textile waste from households is landfilled, $25 \%$ is incinerated, and $3 \%$ is recycled (Tojo et al., 2012). This share will change over the next few years as new incineration capacity currently being constructed becomes operational.

Prior to ending in mixed waste, 25,000 tonnes of used textiles are assumed to be given an extended life via donating to friends and relatives for re-use (applies especially for childrens' clothing), or sold at flea markets or on the internet (Tojo et al., 2012). The latest active on-line market-place, Material bank (www.mpankki.fi), was launched in May 2013 and is open for all sellers and buyers of used textiles and other materials. Traditional flea markets remain popular among citizens.

Due to historical reasons, i.e. shortage of all materials for a long period after the second world war, Finnish people in the 1950s, 1960s and 1970s were very economical and saving of clothes and textiles was common. Hence there are probably to this day numerous households where extensive stocks of various textiles can be found.

The recycling of old textiles and fabrics as raw material in new products is not a significant business in Finland, although volume in the sector and especially in eco-design has grown in the last few years. In 2013, the Recycling Factory, the largest sustainable lifestyle event in Finland, presented a variety of products from over 40 companies, manufactured of recycled materials. As an example, one of the biggest and best known operators in eco-design, Globe Hope, designs and manufactures products from recycled and discarded textiles and uniforms (e.g. from the army), advertisement banners and flags, old sailboat sails, car seatbelts and vintage textiles (such as curtains, tablecloths and bed sheets). The company purchases and gets the materials mainly from companies (uniforms and work wear) and industries (by-products). Globe Hope also 
uses the charity organizations as subcontractors in the procurement of materials (household textiles). The company's turnover was 1.4 million Euros in 2012.

The only commercial company in Finland operating in industrial recovery of textiles is Dafecor Oy,. The company produces nonwoven products for absorbing liquids, covering blankets, industrial wipes and wadding from recycled materials. It receives and purchases used textile residues (e.g. wool and cotton patches) from industries and small enterprises, sorted textile waste from households (sheets and pillow cases), and new clothes that are not merchantable due to design flaws etc. (Metsärinne 2013). Red Cross also delivers sorted cotton to Dafecor. Jeans, underwear, and sweatshirts cannot be used by the company. In total, the company utilizes approximately 100-200 tonnes of recycled textiles per annum and provides employment for six people. Due to the lack of demand for their final products, the company does not use its full capacity (Metsärinne 2013).

Another company, EkoCenter Jykatuote, produces similar products as Dafecor, but operates on a social basis (i.e. providing employment). The company collects 300 tonnes of textile waste from households through containers and sorts into second-hand clothes that are sold in their shop, clothes donated on to charities, textiles used in their own production line, and a waste fraction, which is sent for incineration. In their own production, the company processes textiles according to the fibre. Cotton textiles are processed into industrial wipes, while synthetics and wool textiles are treated so that they can be used as flock and materials for felts. Jykatuote, like Dafecor, is not using the whole capacity of its production line due to lack of demand for the final products. Competing products made from virgin raw materials are more homogenous and their technical characteristics are better known. In the past years, Jykatuote has also reported a shortage in supply of suitable textile material. Wool is important material in the end product (dry felt) because of the good absorbency. However, wool is used less and less as a raw material for clothes and suitable material is sometimes brought from Estonia (Hintikka 2013, Hinkkala 2011).

\section{Export and waste management prices}

In the market for used textiles, the largest sums are given for reusable second-hand clothes. Reusable clothes can be sold for EUR $4 / \mathrm{kg}$. Clothes in very good condition are priced individually according to the condition and type of the textile when selling it in the second-hand shops. (Hinkkala 2011). According to operators in the reuse and recycling (Hintikka 2013, Huopalainen 2013), market prices for textiles that are not sold in 
Finland for reuse vary between EUR $0-2.5 / \mathrm{kg}$ and depend on the material, homogeneity, and the type of used textile. Recycling companies can pay EUR $0.1-0.3 / \mathrm{kg}$ for used domestic textiles and can carry all or part of the transportation costs. Used textiles brought from Estonia cost less than EUR $0.3 / \mathrm{kg}$, but transportation increases the costs. Excess textiles from Jykatuote are sometimes sent to Estonia for free and the client bears the transportation costs (Hintikka 2013). UFF sells clothes directly from their sorting plant to wholesale buyers, which are mainly participants in the HUMANA organization. Prices vary from year to year and the value of sales to the foreign partners is not disclosed. Domestic wholesale buyers pay according to quality, on average EUR $1.5 / \mathrm{kg}$. (Huopalainen 2013.) Sales to wholesale buyers account for $35 \%$ of the income flow of UFF, the main income flow is from re-usable textiles sold through UFF's retail shops (UFF 2012). Textiles not suitable for reuse or recycling are delivered to incineration at the cost of EUR $1.3 / \mathrm{kg}$ (Huopalainen 2013). Charities are not exempt from this charge.

\subsubsection{Specific drivers for market development}

Drivers and barriers for market development in Finland are similar to those in other EU countries. Legislatively, a driving force in textile recycling is the pressure to fulfil the $50 \%$ recycling target of municipal solid waste (MSW) by 2016, as set in the EU Waste Framework Directive. By 2010, Finland had achieved a recycling rate of 33\% for MSW (EEA, 2013). In Finland, a legislative driver is the Government decree on landfills (331/2013), which will come into force in 2016. The decree sets a ban on landfilling wastes that contain more than $10 \%$ of organic substances. Textile wastes cannot be landfilled after 2016.

Citizens' willingness to sort textile waste is one important driver for market development. According to recent questionnaires on consumer attitudes about textile waste sorting and re-use, citizens would appreciate the possibility to source separate non reusable textile waste from the mixed waste (Aalto 2013, Ahonen 2012). The collection network for reusable clothes and textiles is seen to operate relatively well; improvement is needed regarding textile waste collection.

Textile waste from trade and industry are easier to recycle than textiles from households, as residues from industry need no washing or removing of certain parts that would hamper the process. 


\subsubsection{Specific barriers to market development}

The biggest barrier for achieving properly functioning markets for used textiles is the lack of demand for end-products. Although resale and reuse of clothes in flea markets and among relatives and friends is not uncommon, eco-designed products based on used textiles are still a niche market with a low demand. The situation for products produced on an industrial level from used textiles is not much better.

The following can be seen to represent barriers for higher consumer demand for products based on used textiles: general economic wealth, low price of new clothing, and the potential waste stigma related to waste-derived products in general. In a high income country, transportation, storing, sorting, washing, and hand cutting are work phases that increase the costs of eco-design products compared to virgin products, which are more likely manufactured in low income countries. These factors make it difficult to manufacture competitive products from recycled materials and also hinder the generation of new business concepts. In addition, a general barrier in the field is the low quality of used textiles, which weakens the possibilities for reuse. In some cases, the biggest barrier is not the lack of end-product demand, but the lack of suitable material for production. This lack of suitable material is superficial: Finnish statistics show accumulation of textiles in households and a large amount of textiles in the mixed waste i.e. the materials exist but they are not made available to recyclers.

\subsection{Iceland}

\subsubsection{General overview of the market conditions}

The Icelandic Red Cross is the dominating actor in Iceland in the collection of used textiles. They collect approximately 1,400 tonnes of used textiles (and shoes). The Red Cross primarily collects used textiles via containers established at municipal waste recycling centres as well as at more local recycling stations in the Reykjavik area. The Red Cross cooperates with Sorpa, a municipally owned waste management company operating most of the recycling centres in the Reykjavik area. In addition, the Red Cross has its own containers in public spaces or outside their stores or offices in most towns. Sorpa collects and transports the used textiles collected at recycling centres to the Red Cross in Reykjavík at a very low price, covering only a part of Sorpa'a actual collecting and transporting costs. 
The Red Cross does not need any specific permission to set up containers at recycling stations due to lack of competition in the collection market. The municipalities and waste management companies view the collection as an environmentally friendly means for support the charity. The containers which are set up in public spaces or outside the offices of the organisation are subject to the permission of the property owner. There are, however, no recorded cases of property owners denying the organisation permission to set up containers, or demanding a fee to do so. ${ }^{8}$

Unlike some of the other Nordic countries theft from containers is not an issue in Iceland.

The majority of used textiles collected by the Icelandic Red Cross is exported and sold to sorting stations in the Netherlands and Germany (around 1,350 tonnes in 2012). The profits are used for charitable activities in developing countries. Around 50 tonnes of textiles stay on the Icelandic market, where the biggest fraction is sold at the charity's second hand stores. A very small fraction of the collection $\left(2 \mathrm{~m}^{3} /\right.$ month) is sent to two sheltered workshops for rag production. The sorting carried out in Iceland by the Red Cross is minimal as they sell the exported textile as "unsorted." However, they do remove the garments they believe they can sell in their stores in Iceland before export. There are no textile recycling facilities in Iceland, so all used textiles not sold in these few stores are exported regardless of the quality.

In addition to the Red Cross, at least four other charity organisation collect used textiles over the counter in their stores. These comprise the Salvation Army, Subvention for Mothers, ABC Family and Iceland's Family Aid. These organisations sell their collected textiles in their own stores in Iceland. Unsold textiles are donated to the Red Cross for export. The total contribution of these four organisations to the total amount collected is very small.

Apart from the system described above a fair amount of used textiles is traded via other second hand stores or is bought and sold by private and/or commercial actors via the internet. However, there are no statistics available concerning the quantities traded.

8 The Icelandic Red Cross (2013): Personal communication. 


\section{Export prices}

As the Red Cross is the main/only exporter of used textiles, the export prices can be estimated from the revenue of their exports. The 1,350 tonnes of used textiles exported in 2012 gave a revenue of ISK 68 million. ${ }^{9}$ The export price is thus around ISK $50 / \mathrm{kg}$ or approximately EUR 0.30/kg.

\section{Prices for waste treatment}

As noted earlier Sorpa only charges small amounts for the collection of textiles wastes at their recycling stations and the transport from there to the premises of the Red Cross. The Red Cross does not either have to pay any fees for setting up containers for collection neither at municipal recycling stations nor in public spaces or outside their offices. A common price for mixed waste to landfills is ISK 7-9/kg (EUR 0.04-0.06/kg). ${ }^{10}$

\subsubsection{Specific drivers for market development}

The market for used textiles in Iceland is flourishing as "retro-stores" seem to be a rapidly growing business supported by a strong trend within the younger generation. The price tags for second hand clothing in Iceland is reasonably high, which reflects a high willingness-to-pay for second hand clothing in spite of a constant supply of new collections in high-street shops at relatively low prices.

The retro business is supported mainly through two different kinds of operating businesses. On one hand, charity organisations such as the Red Cross and the Salvation Army sell used clothes in their stores for a low price and often by the kilo. The garments offered in these stores are sourced in Iceland and are the result of textile collection through containers (Red Cross) or through the stores (Salvation Army etc.). They are therefore of various quality and do not necessarily follow a certain style. The "retro-store" movement, meanwhile, offers clothing of a higher quality and consequently with a higher price tag. The clothes in these stores are ordered from suppliers in the US and Europe and are usually of a specific era or style. These suppliers buy sorted textiles of this specific genre from collection centres such as the one that the Icelandic Red Cross sells their unsorted textiles to. So in theory these clothes could

\footnotetext{
9 The Icelandic Red Cross (2013): Ársskýrsla 2012. (Annual Report 2012). http://raudikrossinn.is/doc/10417652?wosid=false

${ }^{10}$ Information from the webpages of three different municipal landfills.
} 
originally have been collected in Iceland. However, it is estimated that less than $1 \%$ of textile collected through containers will meet the quality (and style) standard of these stores. ${ }^{11}$

The drivers for this market in Iceland are most likely the same as or similar to the other Nordic countries with an increasing demand for second hand clothing being the most important one. The growing demand can in its turn be explained somewhat by the development of trends as second hand clothing became an important part of the fashion of the younger generation.

\subsubsection{Specific barriers to market development}

So far the collection of textile waste in Iceland has been solely in the hands of charity organisations. As the amount of textile collected is of a small size and the fraction of "retro-clothing" is almost none, it is not economically attractive for private actors to become involved in the collection. It can be assumed that the reason for the high percentage of textile waste not being collected through the Red Cross containers is that people are not aware of the fact that there is also a value in low-quality textile as these can be sold to the recycling stations in Europe generating profits for the charity. Lack of public awareness can thus be seen as a barrier.

\subsection{Norway}

\subsubsection{General overview of the market conditions in Norway}

The collection of used textiles is well established in Norway, although there have not been established any branch agreements within the Extended Producer Responsibility system similar to other types of waste (packaging, WEEE, batteries etc.). Collection and sales is mainly performed by two different charity organisations (Fretex AS and UFF Norge) from collection containers and in collaboration with a number of Norwegian municipalities. In the Drammen region, however, the intermunicipal waste company representing nine different municipalities currently collects textiles in cooperation with a private company called

${ }^{11}$ Spútnik Retro store (2013): Personal communication. 
Hofman Renotec who sends textiles to Poland and Lithuania. The amount collected per year is about 500 tonnes (RfD 2012). The textiles handed in to all collecting organisations are mostly clothes and organisations specify that they should be usable and clean. The largest actors do not collect textiles other than clothing.

There are no legal restrictions in Norway on who can collect textiles. However, if the collector is a charity and the money raised by selling collected textiles are not donated to the given charity purpose, the activity is considered as fraud and may be reported to the police. There is a foundation called Innsamlingskontrollen that offers charitable organisations voluntary registration where key information about the charity is publically available. Registration requires documentation that more than $65 \%$ of the collected values are given to the charitable purpose. This provides assurance for citizens wishing to donate.

Containers for collection of textiles are mostly situated at recycling centres in agreement with the relevant municipality or by shopping malls, grocery stores and gas stations in agreement with private property owners. It is up to the individual municipality what criteria they define for who may be given permission to set up containers.

The organisation that collects the largest amount of used textiles in Norway is Fretex, who collected 11,730 tonnes textiles in 2012. Fretex has 1,800 collection containers distributed all over Norway, 4 sorting facilities and 12 facilities for preparation for export and more than 40 second hand shops. $86 \%$ of the textiles collected were exported $(10,145$ tonnes) (Fretex, 2012). The exported amounts are sold as reusable and are sent to Europe, Asia and North Africa where they are sorted and sold. There are no statistics on amount of reuse and recycling of the exported textiles. The Fretex turnover for exported textiles was NOK 51 million in 2010 (Laitala et al., 2012).

UFF Norge collected about 7,707 tonnes textiles in 2012. The amounts of collected textiles are increasing. They have 2,200 containers and the preliminary sorting of the textiles is performed in 17 pre-shipment facilities in Norway, while main sorting is performed in Lithuania, Estonia, Bulgaria and Slovakia. Most of the clothes and shoes are sold in Eastern Europe, but some is sent to Asia and Africa for reuse or material recycling. Only $0,3 \%$ is sold in their two second hand stores in Norway.

The communicated value of collected textiles by UFF Norge is estimated to NOK 18 million in 2012 (Laitala et al., 2012).

One private company in Norway has been identified that collects textiles in collaboration with nine municipalities and some local sports associations. The textiles are exported and sold on the Eastern European 
market. The amount collected in 2012 was 630 tonnes (Drammens Tidende 2011).

In addition to Fretex and UFF Norge there exist a range of initiatives for collecting textiles for charity purposes. The private market is also characterized by a lot of flea-markets arranged by local sports associations and school groups, as well as internet pages where consumers can sell and buy second hand clothes.

Textiles are (together with WEEE and metals) considered as the waste type most susceptible to theft (Ramboll, 2012). UFF Norge estimates that as much as $10 \%$ of the clothes collected from containers are stolen (UFF Norge, 2013). Exported goods from Norway must be declared for Norwegian Customs and customs must be paid. The customs for used clothes is similar to customs for new clothes (Norwegian Customs, 2013). Clothes that are exported illegally avoid customs, which may lead to tough competition for legal actors.

\section{Export and waste management prices}

No information on prices for export of collected used textiles by Norwegian collectors was found by the researchers. Amongst the costs for collectors of used textiles is the price for waste treatment for textiles that cannot be resold. Prices vary and can be negotiated with the local incineration plant. However, no overview of incineration prices was found.

\subsubsection{Specific drivers for market development in Norway}

The Norwegian legislation concerning textile waste is mainly based on waste prevention principles (NOU 2002). As collection of used textiles is based on NGOs and charity organisations the amount of textiles reused and recycled is closely connected to the goodwill of consumers more than the duty of consumers. As it is estimated that about between 25$33 \%$ of the textile that ends up as waste could have been reused, higher collection rates is undoubtedly possible.

There is a growing trend in Norway for redesign of used clothes. An example of this is a book published by the celebrity, Jenny Skavlan. The book is called Sy Om ("Re-Sew") and describes how to redesign your clothes to give them longer service life. Jenny Skavland has also embraced the Shop stop trend which is also increasing in Norway, a trend where consumers refrain from shopping during a defined time period (Dagens Næringsliv, 2013, Min Mote, 2013). These kinds of trends may lead to increased demand for second hands clothes in Norway and increased awareness of donating usable clothes rather than considering 
them as residual waste. However, finding evidence for this or quantifying the consequences is difficult.

Design and redesign has been introduced as an optional subject in the Norwegian lower secondary school, where one of the main objectives is to raise awareness about the value of design and redesign in an environmental and social perspective (Utdanningsdirektoratet, 2012). This may lead to awareness about the service life and end of life of textiles among the younger generation.

The Norwegian Ministry of the Environment released in august 2013 a national waste strategy for Norway. The strategy mentions that the amount of textile waste from households has more than doubled the last 20 years and explicitly mentions different measures when it comes to textiles waste (Ministry of the Environment, 2013):

- Preventive measures for textile waste may be evaluated (together with building waste and WEEE).

- Prevention of textile waste may be achieved by modification in production processes and product design, reduced turnover of textiles, increased service life for products, and reuse.

- EPR system has been evaluated as an optional agreement or as a legal regulation. However, due to the fact that collection of usable textiles has had a positive development (increased), the Ministry of the Environment as a start wants to initiate a dialog between producers/importers of textiles, collectors and the municipalities to discuss challenges, measures, and how can the different actors contribute. Topics include waste prevention, common goals, information measures, and facilitation for collection. Objective: increase reuse and material recycling.

- Include information to consumers about prevention of textile waste when informing about collection system.

The organisation representing the waste collection activities in the Norwegian municipalities, Avfall Norge, proposed in 2012 that textiles should be collected by the municipality as other municipal waste streams. Their opinion is that there should be a national objective for reuse and recycling of textiles and that there should be an EPR system for textile waste (Avfall Norge, 2012). 


\subsubsection{Specific barriers to market development in Norway}

Charity organisations in Norway get VAT compensations for purchased goods and services, but there are a range of exceptions.

In Norway VAT for sales of used goods is only paid based on the profit. In addition sales of used products in second hand shops run by charity organisations are exempted from VAT. However, there are a lot of requirements: profit must go to a charitable purpose, the products in the shop must have been donated free of charge and the workers must be voluntary, unpaid labour. Although Fretex is owned by the Salvation Army, it is run as a corporation and is not legally defined as a charity organization, despite the fact that it is a social enterprise with charitable purposes. This dilemma was raised for the Parliament in 2008 without leading to any changes in the regulations (Finansdepartementet, 2008).

The market for used textiles in Norway is relatively low due to low prices on clothing and wealthy consumers, leading to export to other countries. Separating used clothes that are sellable at a certain price at the Norwegian market requires deep knowledge about the Norwegian market, which is the core competence at the sorting facilities of Fretex (Lium and Bremnes, 2007). However, due to high labour costs in Norway a large quantity of textiles are exported and the sorting for reuse and recycling is done in countries with lower wages. As of today there is no recycling plant for textiles in Norway. Hence there is no local demand for textile waste for recycling. There have been several initiatives for establishing different recycling plants. However, the economic conditions are poor due to high labour costs (Laitala et al., 2012).

Fretex has stated that used clothes from other countries such as the UK is worth as much as $50 \%$ more than the Norwegian ones at the Eastern European market due to variation in trends and styles (Drammens Tidende, 2011).

One of the initiatives was a company called Ultimat AS, who in 2005 established production of an insulation material based on textile waste from households and from industry. According to the company the product had similar quality to mineral wool, but with less energy demand in production. The production was shut down in 2008 due to lack of funding and tough competition (Laitala et al., 2012).

In 2003 UFF Norge shut down its sorting facilities in Norway due to high cost level in Norway, and due to a more detailed level of sorting in Eastern Europe. According to UFF Norge, sorting in Eastern Europe ensures that a higher share of the collected textiles are reused because of closeness and knowledge about the used textile market and well established communication between sorters and customers (UFF Norge, 2013). 
For many years Fretex had material recycling plants in Norway for collected textiles that could not be sold, shoddy production in Stavanger and carpets for humanitarian aid in Forsand. However, these facilities became non profitable for Fretex, and they were both sold in 2010. The reason was market conditions and increased competition (Laitala et al., 2012).

Since the organisations that collect textiles in Norway only ask for usable clothes and shoes, there is no organised collection of textiles that could have been material recycled. In addition, separating unwanted textiles from residual waste is not considered as a civic duty as it is for paper and plastics, but rather as a charitable (and hence optional) action.

It is clear that a lot of textiles (both reusable and recyclable) ends up in the municipal waste and is sent to incineration, as the potential of increased annual collection of used textiles from households is estimated to be 37,000 tonnes or 7.4 kg per capita per year (Laitala et al., 2012, Norwegian Ministry of Environment, 2013). This indicates a lack of economic incentives for reuse and recycling of textiles and a lack of information to consumers about how to recycle used clothes and shoes.

Unsold faulty clothes from high street stores represent another potential flow of textiles that can be used or recycled. A survey of the largest Norwegian clothing chains revealed that most clothing shops in Norway regularly donate clothes (such as garments with faults, samples, returns and unsold garments) to charity organisation (Granum, 2013). The shops normally demand that the donated clothes cannot be sold in Norway and must be exported. However, shops in Norway may meet an economic challenge when it comes to donations because usable clothes with a value may not be depreciated in their accounts. Hence, there is no economic incentive to donate rather than define garments as waste. (Granum et al., 2013).

\subsection{Sweden}

\subsubsection{General overview of the market conditions}

The Swedish market for collection and handling (including sorting and selling for reuse and recycling) of used textiles is traditionally dominated by charitable organisations, representing an estimated $90 \%$ of the market (Rosinski, 2013). The rest is collected and handled by private stakeholders.

Most charitable organisations primarily collect the used textiles in textile containers. These are usually placed at recycling points and recy- 
cling centres, but to some extent also at other public places (e.g. outside supermarkets). (Enebog, 2013; Rosinski, 2013). In addition, some charitable organisations, e.g. Myrorna as a part of the Salvation Army, collect smaller volumes in their second hand stores or via collection directly from households (Enebog, 2013). The Swedish Red Cross collects its used textiles exclusively in its 279 second hand stores (Dahlin, 2013). Most private textile collectors use textile containers, but to some extent they also collect the materials in their own shops or via (irregular) curb side collection.

Putting up textile containers requires a permit, though a uniform procedure for granting permissions is missing. In the lack of official authorizing bodies for setting up textile containers, different bodies (e.g. municipal administration, police and companies responsible for collecting EPR materials) grant permission depending on the applied location for the textile containers. There are no formal standard regarding permit conditions e.g. type of organisation, container and treatment of the collected materials as well as official registration as a collecting organisation (Rosinski, 2013). See also "Specific barriers to market development" below.

Clothing and household textiles (e.g. sheets, towels and curtains) are dominating fractions in the collected materials. Women's clothing constitutes the largest share of the collected clothing (due to higher consumption) (Dahlin, 2013; Rosinski, 2013).

Most Swedish charitable organisations collecting textiles are members of the non-profit organisation Ideell Second Hand. In 2011 the charitable organisations organised in Ideell Second Hand collected 25,781 tonnes of used textiles (Ideell Second Hand, 2012). Assuming an additional 10\% used textiles are collected by private collectors via containers (Rosinski, 2013)and that about $4 \%$ of the content in the textile containers are stolen before collection (Rosinski, 2013), annually about 29,000 tonnes of textile are collected (corresponding to ca. $3 \mathrm{~kg} /$ person). This would imply an overall collection rate for used textiles in Sweden about 20\%. We assume that about half of the remaining $80 \%$ ends up in mixed municipal household waste and gets incinerated. The remainder is probably a mix of home storage and volumes collected via municipal recycling centres which in fact also ends up being incinerated.

Used textile collectors handle the sorting of the collected materials in different ways. Some organisations (e.g. Swedish Red Cross) carry out the sorting completely "in-house" (Dahlin, 2013). Others sort a part of the collected textiles internally (usually differentiating between textile for reuse in Sweden, textiles for reuse in the rest of the world and textiles for material recycling) and sell another part unsorted primarily 
within the EU e.g. Germany and Netherlands for fine sorting in those countries (Enebog, 2013; Rosinski, 2013). Sorting in Sweden is carried out manually. Trained personal with a good knowledge in the Swedish second hand market is essential in order to identify the used textiles suitable for reuse in Sweden (Enebog, 2013). Sorting in recycling installations in the EU (e.g. in Germany and the Netherlands) is often carried out half-automatically, i.e. the lifting and movement of the textiles is done automatically and only the actual sorting manually. In cases where the charitable organisations do the sorting internally, the number of sorted fractions is low (often only two or three categories) (Dahlin, 2013; Enebog, 2013; Rosinski, 2013), whereas recyclers buying unsorted used textiles from Sweden sort them in up to 300 different categories (Rosinski, 2013).

About $50 \%$ of the used textiles collected by the Swedish Red Cross, the only charitable organisation collecting exclusively "over the counter" in its second-hand stores, can be sold for reuse on the Swedish market. Traditionally the remaining used textiles have been sent for incineration, but since 2013 these volumes are mostly sold for reuse and recycling in the EU (Dahlin, 2013). However, the Dutch KICI foundation has since April 2013 been partner to the Red Cross with the objective that within a year or so they will manage all of the textiles that cannot be sold in the Red Cross second hand stores (Dahlin 2013). Several depots around Sweden have been created to facilitate collection of textiles for transport to the Netherlands where additional sorting is made for reuse, recycling and disposal (Jansen and Vos, 2013). KICI was also a partner in the textile collection pilot in the municipality of Stockholm and is currently in discussions on cooperation with other charities for export of textiles including Emmaus Björkå and Stadsmissionen (Dahlin 2013). Apart from the income from KICI, there will also be a significant reduction of incineration costs (Dahlin, 2013).

The pre-sorted remainder from the Swedish Red Cross is of high quality - equal to the quality of unsorted used textiles from container collection (Jansen, 2013). It can therefore be assumed that the quality of used textiles collected "over the counter" in many cases show higher quality than used textiles collected via textile containers.

Another charity that collected used textiles, Human Bridge, works with the Boer group sorting facilities in the Netherlands and Germany. The Boer group has a "Certified Textile Sorting Process Assessment Foundations" (Beoordelingsgrondslag Gecertificeerd Textielsorteerproces) and all textiles are goes to reuse and recycling ("Boer Group - A world of textile recycling," 2011). Human Bridge has chosen this partner to ensure that nothing goes to 
landfill or incineration as for their own sorting in Sweden. Previously they cooperated with several sorting facilities in Eastern Europe but most of these could not guarantee zero landfill (Rosinski 2013).

From the used textiles collected in textile containers approximately 7,500 tonnes is sold for reuse in Sweden with 19,000 tonnes exported for reuse and/or recycling in other countries (Tojo et al., 2012; Enebog, 2013; Rosinski, 2013). The remaining 2,000 tonnes of low quality is incinerated in Sweden (Rosinski, 2013).

One explanation for the fact that it is incinerated rather than recycled, might be that the market price for used textiles usually is a mixed calculation that includes profits from reuse. Thus, very few if any recycling companies pay for used textiles that are not suitable for reuse (at least to some extent) since the price for used textiles is too high to make recycling economically viable. In addition, there are many incinerators but no companies that recycle used textiles in Sweden. The transport costs for export for recycling are higher than sending for incineration (see under prices later). Of the unsorted textiles collected in Sweden and sold in the EU market, typically 95\% is reused and recycled and 5\% incinerated. The $95 \%$ is approximately equally split between reuse and recycling (Rosinski, 2013).

The Swedish market for collection, reuse and recycling of used textiles has an increasingly high level of competition (Dahlin, 2013; Enebog, 2013; Rosinski, 2013). The demand for used textiles is increasing and the competition for getting hold of them is strengthening. The increased demand for second hand textiles reflects to some extent the increased awareness of the environmental impacts of textiles (Enebog, 2013). New collectors are entering the market - with differing levels of legitimacy. Charitable organisations using textile containers for collection report that new (and sometimes anonymous) containers are placed next to theirs without permission for doing so. The objective is obviously to divert parts of the used textiles from the traditional textile collection in the assumption that consumers either do not differentiate between the different containers.

In addition, retailers increasingly influence the flow of used textiles (e.g. H\&M in its campaign "Don't let fashion go to waste"). Furthermore, some municipalities are considering entering the used textiles market and end previous collaborations with charitable organisations. To some extent the increased interest in collecting used textiles might be technology driven, e.g. companies develop better and more efficient techniques for textile recycling (including recycling of materials with lesser quality) and clothing producers increasingly use better recyclable materials (Enebog, 2013). 
It can be assumed that a range of new players are entering and testing the market for collection, reuse and recycling of used textiles and that the traditional market will change before stabilising.

Collectors using textile containers report increasing cases of theft from the containers. As mentioned earlier about $4 \%$ of textiles deposited in containers are stolen (Rosinski, 2013). There are two different types of theft: on the one hand textile containers are broken into (often damaged in the process) in order to find single pieces of valuable clothing that can be turned into cash. On the other hand organised leagues steal the complete content of the containers on a regular basis (using children or small adults that are let down in the containers, emptying them from the inside and then assisted out again). These leagues do not damage the containers since they intend to come back and empty the container again. (Rosinski, 2013) Generally, there seems to be a larger problem with thefts in the south parts of Sweden compared to the northern parts (Enebog, 2013).

Textile collectors report decreasing quality of the collected materials compared to some years ago. It is believed that one of the main reasons for this is the increasing internet trade of used textiles by private consumers (e.g. on www.blocket.se and www.tradera.com), resulting in that a larger proportion of "not sellable" clothing is given to the traditional textiles collection (Dahlin, 2013).

\section{Export prices}

There are no official data on prices paid for used textiles collected in Sweden. However, information from different charitable organisations involved in collection, reuse and recycling of used textiles give a general overview.

The price typically paid for unsorted textiles from Sweden is DKK 3.70-5.80 per kg (SEK 4.50-7.00/kg). The lower price range also applies to semi-sorted fractions that include textiles for reuse outside of Sweden and for recycling (Dahlin, 2013; Enebog, 2013; Rosinski, 2013). The price paid by less legitimate stakeholders (e.g. some Eastern European companies not paying minimum wages and for employees' social security) probably lies above these levels.

\section{Prices for waste treatment}

In semi-sorted fractions that do not include any textiles for reuse, the collecting organisations have to pay DKK $0.40-0.85$ per $\mathrm{kg}$ (SEK $0.50-1.00 / \mathrm{kg}$ ) in transport costs to send them for material recycling within the EU (Rosinski, 2013). It is usually very hard to find recycling companies that pay for or even accept these materials if they are not part of a larger package including to some extent also reusable textiles (Enebog, 2013). 
The price for sending textiles waste for incineration differs depending on available waste incineration capacities and also on how municipalities choose to charge the collection organisations. In some municipalities charitable organisations can send this fraction to incineration free of charge, in others they have to pay market prices. Typically costs for sending this type of textiles to incineration vary between DKK $0.44-0.87$ per $\mathrm{kg}$ (SEK $0.50-1.00 / \mathrm{kg}$ ) - i.e. typically no higher than collectors pay for sending non-reusable textiles abroad for material recycling (Rosinski, 2013). The additional transport fees for materials going to incineration are generally lower than for materials going to recycling due to the large number of incinerators in Sweden.

\subsubsection{Specific drivers for market development}

Stakeholders report that the collection, reuse and recycling of used textiles has become more in focus in Sweden over the last couple of years. Possible reasons are among others the goal for increased reuse and recycling of used textiles set by Naturvårdsverket (Swedish Environmental Protection Agency), increased public awareness about the environmental impacts of textiles and an improved market for used textiles.

One of the main drivers for the market development is stated to be the large flows of used textiles as a result of an "over-consumption of textiles." The level of consumption of clothing and household textiles in Sweden increased by $40 \%$ between 2000 and 2009 (SMED, 2011). At the same time, the collection rate for textiles is still relatively low in Sweden (ca. 20\%) compared to other countries in Central Europe, where collection rates can be as high as 75\% (Rosinski, 2013).

Increased quantities of collected used textiles would enable a more efficient handling (e.g. sorting and logistics) of the materials and make the Swedish (and Nordic) market conditions more profitable. Hence, a main challenge for market developments is increasing quantities of collected used textiles. In order to achieve this, some textile collectors would welcome official quantitative targets for collection, reuse and recycling of used textiles on a national or regional level.

\subsubsection{Specific barriers to market development}

\section{Lack of coherent permit process}

There is an urgent need for a dialogue between municipalities and textile collectors in order to create an improved infrastructure for the collection of used textiles. Such an infrastructure could include mandatory 
textile containers at all recycling points and recycling centres as well as at strategic public places. A high level of transparency by the collecting organisations and companies as well as feedback to consumers regarding collected amounts as well as regarding environmental and social benefits from the collected used textiles are also considered important as a driver for increasing material flows.

As mentioned earlier, textile collectors need a permit to set up containers. However, no authority is given the clear responsibility or guidance for proper implementation and municipalities have chosen to handle this in different ways. Municipal administrations often refer used textile collection organisations wishing to set up a collection container to the recycling points for packaging waste (glass, paper, metal and plastic packaging) and newspaper wastes covered by the extended producer responsibility run by Förpacknings- och Tidningsinsamlingen (FTI). FTI on the other hand argues that textiles are not covered by extended producer responsibility regulations, denies permits to place textile containers at the recycling points and refers textile collection organisations back to the municipalities (Rosinski, 2013). As a result, textile collectors sometimes give up and either choose not to set up a container or to do so without a permit. Textile collectors report that the handling of permits varies greatly between municipalities. Some are very committed and grant permits on strategic places, others delay the permit procedure and/or need several reminders to deal with the applications. One reason for not granting permits might be fear of other wastes being discarded around the containers, causing visual pollution and additional waste collection costs. (Enebog, 2013).

Another general problem is the lack of control of permits as well as the lack of sanctions in case of missing permits (Rosinski, 2013). This results in a large number of illegal textile containers, a lack of transparency of material flows and to some extent to a distorted market due to the fact that a large part of the collectors without permits presumably do not comply with social and environmental standards.

Municipalities issuing permits for putting up textile containers often ask for a so called "90 account" from the collector (Rosinski, 2013). This is an account that only charitable organisations approved by the non-profit organisation Svensk Insamlingskontroll (www.insamlingskontroll.se) possess. There is not a formal or legal requirement for textile collectors to possess such an account. It appears, however, that municipalities in this way want to reduce the risk of dubious collectors. This constitutes a market barrier for legitimate private actors. 


\section{Definitions of waste}

According to of the Swedish Environmental Code (1998:808) ${ }^{12}$ any object, matter or substance which the holder disposes of or intends or is required to dispose of is defined as waste. The definition applies also to used textiles (regardless whether the used textiles can be reused or not) and causes to some extent market barriers since the handling of waste underlies special regulations. However, for the time being most collecting organisations bypass this problem by collecting the used textiles as donations. This requires a conscious decision by citizens to donate instead of throwing away. In this way, the used textiles are collected before they turn into waste. The above mentioned definition of waste, however, makes it difficult legally for charitable organisations and private collectors to extract textiles from mixed waste streams.

Moreover, although as a result charities are legally able to collect reusable textiles as donations they are not permitted to collect nonreusable textiles whether for recycling or disposal. Meanwhile, the municipalities are unlikely to be allowed to collect and sell textile that is not waste (Konkurrenslag, 3:27).

\section{Small size of market}

As mentioned, the relatively small amount of collected used textiles in Sweden is considered as a barrier to further market developments and green job creation within Swedish borders. Higher material flows would allow more efficient and profitable handling (logistics, sorting etc.). For example, sorting of collected used textiles into more differentiated categories in Sweden (instead of in Germany, the Netherlands and Eastern Europe) could result in higher value in the collected materials. Higher material flows for sorting in Sweden (or somewhere else in the Nordic Region) could be achieved by increasing collection rates as well as by coordinating existing material flows (from different organisations, regions and countries).

In addition, a coordination of logistics (e.g. intermediate storage until a whole container of a specific category of used textiles is full and ready for sale) and sales could lead to improved market conditions. A current barrier is that there is no administrative body for this and that charitable organisations, representing about $90 \%$ of the collection in Sweden, are not allowed to trade in others used textiles (or they will lose their

12 Chapter 15 , section 1. 
tax benefits in terms of exemption from VAT). Thus, every organisation is only handling its own material flows even if coordination might be more profitable. (Rosinski, 2013)

\section{Lack of recycling market}

As mentioned earlier, the most common way to handle pre-sorted rests that are not suitable for reuse is incineration (not recycling). There are different possible explanations. It might be a matter of habit and/or other priorities in the collecting organisations. The focus on used textiles only suitable for recycling is a quite new occurrence in Sweden. There might even still be a lack of awareness among the collectors. The amounts of used textiles that are sorted by charitable organisations in Sweden are still small; the majority is sold unsorted (Rosinski, 2013). This means that the potential volumes of (pre-sorted) used textiles that are only suitable for recycling is very small. Therefore, incineration of these rests has been considered as the easiest and cheapest solution.

Part of the reason that the collected amounts suitable for recycling but not reuse is so small is that citizens who donate textiles via containers or over the counter in second-hand shops choose to give only a part of their used textiles to the textile collection. Reasons might be that consumers do not expect a reuse and/or recycling market for certain used textiles (e.g. underwear (experiencing very low demand in Sweden, but high demand in other countries) and stained or worn-out clothing, or simply because some collectors specifically ask only for textiles suitable for reuse.

However, a considerable part of the currently not collected used textiles can be used - either for reuse or recycling. Thus, some collecting organisations in Sweden would like to increase the collected volumes by asking the consumers to collect all their used textiles and let professionals with better knowledge of the markets for used textiles carry out the sorting. Other collecting organisations fear that increasing volumes of collected used textiles would include too much material of low quality and make sorting more costly.

\section{Distorted markets}

High labour costs are not per se considered as a barrier for the collection, reuse and recycling of used textiles in Sweden given the assumption that all stakeholders handling the collected materials would comply with environmental and social standards. A large part of the used textiles collected in Sweden are either sorted nationally or in other countries with similar high labour costs (such as Germany or the Netherlands). The problem is rather a distorted market caused by some com- 
panies (e.g. in Eastern Europe), that do not comply with environmental and social standards (i.e. with lower labour costs) and thus offer higher prices for the collected materials.

\section{Lack of knowledge}

Experience shows a lack of knowledge in companies and organisations where large quantities of used textiles arise (such as hotels, laundries, hospitals, prisons etc.) that these might be reused or recycled instead of incinerated. There is also a lack of knowledge in businesses and other organisations generating large amounts of used textiles arise. A better overview of sources for large amounts used textiles and how they could be reused or recycled would help increase collection, reuse and recycling rates.

Finally, there is a lack of knowledge about the implications the increased collection of used textiles might have on the qualities of the collected materials (e.g. larger proportion of used textiles not suited for reuse) as well as on the market for used textiles (e.g. when does saturation occur and what happens to the market prices when it does) (Enebog, 2013).

\subsection{Summary of Nordic Flows and Markets}

It seems that the Nordic market conditions for used textiles are marked more by their similarities than their differences. This may be a sign of the increasing global nature of the market.

\subsubsection{Collection is still dominated by charitable organisations}

In all the Nordic countries the majority of the collection operations are carried out by charitable organisations. The income from their collections is an important contributor to financing their work. Moreover, in most countries just a few charitable organisations dominate the market, although this is undergoing change (see below). The organisations tend to collect via containers, for which in general permission is required from the municipality or the landowner for private land. However, in Sweden there is lack of coherence on who has the responsibility for granting permission to collect textiles. Municipal administration, police and companies responsible for collecting EPR materials grant permission depending on the location. 
In general, there are no criteria for who may apply for permission to set up containers in Nordic countries. In Denmark, however, the state guidelines suggest that collecting companies must be charities or have a partnership with a charity. Similarly, in Sweden municipalities often ask for a so called "90 account" from the collector which is an account that only charitable organisations can obtain. In Norway any organisation can apply for permission to put up containers but those claiming charitable status must provide externally verified assurance that the money raised is being applied to charitable work. Some collection organisations in Nordic countries only collect via their shops and in general these receive textiles of average higher quality than those collecting via containers.

A the lack of control of permits as well as the lack of sanctions in case of missing permits is also a problem in some countries. This results in illegal textile containers, a lack of transparency of material flows and to some extent to a distorted market.

\subsubsection{The competition is increasing as prices rise and the market diversifies}

While in Iceland due to the small size of the market there is only one main actor, in other Nordic countries the market is diverse and the number of actors growing. This is happening through a number of different processes. A limited but growing number of clothing high street chains brands are beginning to carry out collection of used textiles in their stores in response to calls for a more sustainable fashion industry, often in partnership with a textile collecting organisation and/or company. These and other private companies are entering the collection market as prices for used textiles rise. In some countries (e.g. DK, NO) this has been inhibited somewhat by disadvantageous conditions for private operators with respect to VAT rules and differential treatment with respect to setting up of collection containers, but is nevertheless still occurring. Finally, a growth of illegal operations is being reported in several countries. This includes doorstep collections by non-registered organisations or direct theft of donated textiles from containers or other drop-off points. Estimations of losses due to illegal activities range between $4 \%$ in Sweden to $10 \%$ in Norway. In Finland and Iceland, however, this is not reported as a common problem. 


\subsubsection{The supply of quality used textiles is not rising as rapidly as the demand}

Demand for products from charity shops in Nordic countries, probably dominated by clothing, is reported as having increased significantly in the past couple of years. This is believed to in part to have been catalysed by the economic crisis and resulting pressure on incomes, as well as the fact that second hand and vintage clothing has become trendy, due to change in values. However, the supply of used textiles has not increased to match increasing demand.

\subsubsection{There is still great potential for more textiles to be collected, particularly non-reusable textiles}

Nevertheless, a significant proportion of textiles are still disposed of in ordinary household or bulky waste and ends its days in incineration (DK, SE, NO) or landfill (FI, IS). The share of textiles put on the market which eventually ends up in separately collected streams range between $20 \%$ in Sweden to over 45\% in Denmark. The remainder indicates the upper limit of the proportion which ends in incineration and landfill. This represents a significant loss of useful products and materials.

The majority of the separately collected used textiles comprises clothing that is suitable for reuse. The focus on separate collection of household textiles has been less strong, and collection of used textiles that are not suitable for reuse even weaker. With respect to the latter most collection organisations actively dissuade citizens from donating textiles that are not suitable for reuse. This is due to a lack of domestic recycling capacity (see later), and the fact that far from being a possible money earner for organisations, it typically costs organisations money to send textile waste only for recycling in other European countries. While there is a market for recycling in Europe, prices are low. Separate collection of textiles waste by municipalities is not carried out to any noticeable extent in Nordic countries possibly for the same reasons that charities generally don't collect non-reusable used textiles.

Where recycling of Nordic collected textiles does occur it is limited to that fraction of mixed quality textiles that are exported for sorting in other countries. In that case it can make economic sense for the sorting organisations to sell the unusable fraction to recyclers.

Incineration of non-reusable textiles also costs money for most collecting organisations, although charities can be exempted from these costs under certain conditions in Sweden and Denmark. Incineration fees are not a strong driver for recycling since the fees are often similar 
to the cost of transportation of low quality textiles for recycling in Europe. In this case incineration is most often chosen as "the easy option." This may in part be due to lack of knowledge of markets.

\subsubsection{Detailed sorting is most often carried out in countries with cheaper labour costs}

The dominant collectors of used textiles in Nordic countries use a wide range of models for subsequent handling of the collected materials. A few carry out detailed sorting of textiles by quality and type within the country where the textiles were collected and sell the sorted fractions on mostly for export but also on the domestic market. Others export or sell all of their collected textiles for sorting in other countries. A third smaller group only collect textiles which they can sell in their own shops. As a general rule of thumb, however, the majority of organisations at least remove the textiles that they can sell in their own shops, and sell or export the remainder for more detailed sorting in countries with lower labour costs. This is because sorting of textiles must still mostly be carried out manually.

\subsubsection{The majority of collected textiles are exported}

The proportion of collected textiles which are filtered off for resale in collecting organisations own shops in Nordic countries represents a fairly small proportion of the total collected. On a national basis this ranges from $10-15 \%$ in Sweden to 30\% in Finland. However, the range is higher between individual organisations that have distinctly different business models. A few of the organisations who only receive textiles donations over the counter only collect items which they can sell for reuse domestically. For most organisations, however, the majority of what they collect is exported for further sorting and subsequent handling in other European countries (see under Chapter 4). This is primarily due to high wage level in the Nordic countries. The wage that would be necessary to obtain Nordic workers with the necessary high skill level cannot be justified by the prices for the sorted fractions. The sorting that does occur in Nordic countries generally relies on voluntary unskilled labour. 


\subsubsection{There are very few companies in Nordic countries recycling textile waste}

Only a few examples of companies recycling textile wastes were found in Nordic countries. This includes one private and one charity organisation producing industrial cotton rags in Finland. Some recycling facilities have closed down in recent years due to difficult economic conditions including the high costs of labour. Two examples of this were identified in Norway. This lack of a Nordic market for non-reusable textiles is a significant barrier to collection of these textiles.

The two recycling organisations in Finland, however, report an opposite situation where they can't obtain a sufficient supply of suitable material for recycling. They can't compete on price for separately collected reusable textiles but sufficient non-reusable textiles certainly exist in Finland. The majority of this, however, still ends in municipal mixed waste.

\subsubsection{There remain legal obstacles to the collection of textiles}

As already identified, in Sweden and Denmark private organisations can find it more difficult receiving permission from municipalities to collect used textiles via containers. Definitions of when or not a product is considered to be waste can also potentially present obstacles to collection of used textiles. In most countries textiles that are considered as waste are officially owned by the relevant municipality who must therefore give special permission to organisations who wish to collect and sell this "waste". In some countries the act of actively donating textiles to an organisation, however, excludes the articles as being considered as waste. However, even in these countries the waste definition rulings present a potential obstacle to waste management organisations wishing to sort textiles waste from other municipal wastes for resale for recycling. Clear end-of-waste criteria for textiles for application in Nordic countries would make operations simpler for collecting organisations.

VAT can also be an obstacle for some actors. In Denmark for example charity organisations are exempt from paying VAT while private collectors must operate under normal business conditions. Luxury secondhand retailers have to pay output VAT, but since they can't refund any input VAT they face some difficult market conditions. In Norway sales of used products in second hand shops run by charity organisations are exempted from VAT. However, profit must go to a charitable purpose, the products in the shop must have been donated free of charge and the workers must be voluntary, unpaid labour. One of the major charitable 
collectors in Norway, Fretex must also pay VAT due to its status as a corporation.

Finally, in a number of countries, high street chains face obstacles in donating faulty or returned textiles to charities due to the fact that they can't reclaim VAT from donated unused textiles. 


\section{The European market for used textiles and textile waste for recycling}

The European market for used textiles is characterised by a number of different actors which operate on the national markets and/or in the European market.

Figure 6 Chain of actors in the European market

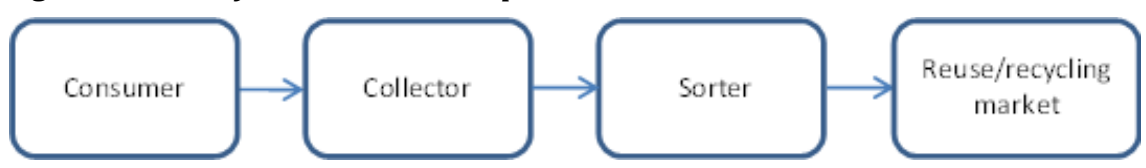

When consumers decide they no longer have a use for a textiles article they have a number of options to either discard, donate or sell them to collectors like e.g. charity organisations (who usually have retained those textiles which they can resell in their domestic second hand shops), professional collectors, illegal collectors, retailer collections, or municipalities. Once the textiles have been collected, there are a large number of buyers who purchase the textiles. The textiles are then sorted, resold, recycled and/or sent for waste treatment according to quality, design and season. Some of the actors manage all of these processes inhouse (see I:Collect box) and others are a part of a longer chain of actors. ${ }^{13}$ Dutch group KICI is another important actor who is currently beginning a cooperation with the Swedish Red Cross. The buyers are mostly located outside the Nordic region.

Much of the textiles which are considered suitable for reuse are compressed into bales and sold to smaller dealers who then sell the textiles as direct reuse in e.g. African or Eastern-European countries. According to the Bureau of International Recycling, more than $80 \%$ of the popula-

13 In the following the common term "buyers" will be applied to both middlemen, sorters, recyclers and other actors who buy used textiles from the collectors. 
tion in many African countries dress themselves in second-hand clothing (BIR 2013).

The textiles which are not suitable for reuse are sold for recycling, which mostly comprises downcycling with uses such as cutting into rags, filing for car-seats, insulation etc. A few mechanical and chemical processes for recycling of fibres have been developed and are in use with the aim of creating new fibres, but there are still obstacles to overcome before these technologies can be implemented on a wider scale. Due to this yet immature market for recycling, the market price for textiles that can be reused is typically far higher than the price for textile waste for recycling. It thus appears that the traded prices to some extent follow/support the waste hierarchy.

There is a small market for recycling of pure polyester but the European market for cotton and blended fibres that can't be recycled mostly comprises the downcycling options mentioned above.

The textiles which are not suitable for recycling are sent to incineration or landfill, in return for an incineration or landfilling fee.

\section{I:Collect}

Many larger European producers have decided to team up with the Swiss textile collectors and handlers I:Collect (I:CO) which is a part of the SOEX Group. The company currently processes around 500 tonnes of used items every day which has been collected at collection points in 74 countries all over Europe and USA. I:CO arranges the pick-up, the sorting, the re-use and the re-cycling. When large producers collects used textile in-store the textiles are brought back to main storages by the existing logistics, from where I:CO picks it up and transports it to a central sorting plant. The contract I:CO makes with individually companies and organisation varies in terms of payment etc.

\subsection{German market for used textiles}

According to EUWID, the second-hand prices for one kilo of collected stock have varied between EUR 0.3 and EUR 0.6 in the past year in the German market (EUWID 2012, EUWID 2013, EUWID 2013a, EUWID 2013b, EUWID 2013c). All prices for used clothes fluctuate over the seasons, but seem to have reached an average level for all collected textiles of around EUR 0.5 per kilo in Germany in the spring of 2013 (EUWID 2013a) although the price for individual sorted fractions can be much higher than this. The quality of German used textiles is, however, considered to be 
rather lower than that in Nordic markets (Danish EPA 2013a), so the average prices for Nordic textiles are assumed to be higher.

Due to these historic high prices in Germany, the market is flooded by illegal collectors of all sorts (EUWID 2013b, EUWID 2013c). At the same time, the private and charitable collectors are now joined by local authorities entering the market for collection of textiles, and actors are stating that the entire market appears to be "in transition" (EUWID 2013c).

The increasing numbers of actors are competing for the supply of used textiles, which is why the prices for collected textiles in Germany have proved to be high for buyers across the country. Hence they report having difficulties in breaking even since their purchase price is high and increasing, compared to the price they can obtain for their sorted/recycled material outputs. BIR Textiles Division President Olaf Rintsch of Textile Recycling K\&A Wenkhaus GmbH has warned how "difficult market conditions" and "unfair competition" is adversely impacting the traditional used textiles industry. Prices for collected textiles has reached "a zenith" and buyers are finding it "almost impossible" to make profits. He underlines that continuously high prices can result in a large number of lost jobs, as recycling businesses close down (BIR 2013a).

\subsection{UK market for used textiles}

The situation in the UK seems to be very similar to the German; the Financial Times last year learned that the prices for second-hand used clothes have tripled in the past five years (Financial Times 2012). According to a price statement from a British recycling news site, the average textile price in the UK is around EUR 0.35 for the mix of textiles collected in textile banks, ${ }^{14}$ EUR 0.61 for shop collections ${ }^{15}$ and EUR 0.8 on average for charity rags ${ }^{16}$ in the first half of 2013 (Letsrecycle 2013).

\footnotetext{
14 Textile banks - this reflects the amount that may be paid to a local authority or a waste management company, usually by a collector for material from textile banks. The payment may be amended if the local authority has to pay a bank hire fee or an element of the collection costs and if a donation is made to a charity. 15 Shop collections - this price indicates the amount which may be paid by a collector to a charity shop for clothes the shop has not sold to the public directly. Prices vary on content from poorer quality material through to clothes and leather items.

${ }^{16}$ Charity rags - this is a general term for material, usually well-presented and often from charity shop collections, delivered to the factory of a larger textile collecting business which often exports used clothing and textiles.
} 
At the end of 2012 it was further noted that the competition in the market was increasing and that textile buyers were struggling with the exporting as a result of the high prices demanded for charity grade material. The increasing prices for collected textiles have meant that more than $10 \%$ of the British Textile Recycling Association members (British association for the textiles buyers) have ceased trading in the last year, and that more are expected to follow due to the high price for their inputs not being followed by increasing prices for their outputs (BIR 2013a; Letsrecycle 2013a).

\subsection{Europe in general}

Whether it is attractive to sort used textiles into fractions for subsequent sale, rather than selling unsorted bales of textiles, depends on the volume of textiles being collected, the price of labour and logistics for the collecting organisations, the risks to the organisation of investing in a sorting facility and the market price for sorted fractions.

There does not seem to be any listings of average prices of textiles traded in the European market, but the listings presented above from Germany and UK are expected to give a good indication of the trends in the market; prices for used textiles are historically high, and the demand is increasing. There are many collectors who fight for the material, and especially in places where collection is not so well organised, the market is challenged by illegal collectors.

The situation for buyers in both Germany and UK is being mirrored elsewhere. In Italy, for example, textile buyers have raised concerns about the current state of the market, with a number of sorting facilities reporting on high prices (BIR 2013a). There is a large pressure by new entrants to the market which are expecting to make quick profits due to the high prices. But some argue that there might also be a high failure rate of new companies entering the market, due to lack of knowledge, expertise and good contacts (ibid).

The differing legal status of textiles as waste within Europe has also been highlighted as an issue. For example, some countries consider clothes deposited in collection banks as waste whereas others do not (BIR 2012). In Germany the view taken by the authorities is that once minimum sorting (treatment) of these used materials has taken place, they fall outside the waste legislation (Rintsch 2008). This proliferation of different rules and regulations means that it is difficult to make the system work on a European scale. Clarification of common European end-of-waste criteria for textiles hasn't been planned in the near future. 


\section{The global market for used textiles and textile waste for recycling}

The used clothing economy links the developed and the developing parts of the world via an integrated and complex market. The market is not only beneficial for the environment in that it keeps used textiles from landfilling, but it also serves as a valuable resource for developing local livelihoods in the developing part of the world. There are obviously many derived effects from this trade in terms of e.g. development, economic and environmental issues and many conflicting interests have been identified in the literature. This overview will however not deal with these issues as such, but rather simply draw a rough sketch of the market structure and flows.

\subsection{Actors in the market for collecting and sorting used textiles}

The global market for collecting, re-using and recycling used textiles is made up of a large number of collectors (both charitable and professional), sorters, fibre recyclers, rag-producers, dealers, brokers, "pickers" and exporters, and the market is in general quite inscrutable (Hansen 2006; Norris 2012a; Norris 2012b).

Similarly to the Nordic and European situation, charitable organisations are also dominating global activities in the collection of used textiles. These organisations supply not only domestic but also foreign markets with second-hand textiles and in particular clothing for both the needy but also the wealthier parts of the populations.

In the $60 \mathrm{~s}$ and 70 s charitable organisations dominated the American (and presumably also the European) clothing retailing scene, but have since been joined by a variety of stores and on-line based companies operating on a for-profit basis (Hansen 2006). Some of these work on a consignment basis whilst others source in bulk from second-hand clothing vendors; and some do both. Some donate their excess garments to 
charity organisations whereas others sell their surplus at bulk prices to commercial second hand clothing dealers (ibid).

Sorting facilities have traditionally been based in Western Europe and North America, but have in many cases been moved to countries where wages are relatively low, since most sorting is still performed manually. As mentioned earlier, used clothing can be exported unsorted, or following sorting in Eastern Europe or in the global south, and are often repacked and re-exported under successive different classifications until they reach destination markets (Norris 2012b). There is no reliable published literature available on this increasingly complex commodity network, which crosses over the borders between legal and illegal activities (ibid).

A company like I:Collect (see Box in Chapter 4) is a relatively new international market player, and several actors have expressed concerns of its entrance to the market. I:CO is a large commercial actor with the capability to take a large market share. I:CO is managing both the collecting and the sorting of used textiles. The company has partnered up with numerous both local and global partners, including large players such as H\&M, Jack \& Jones, Esprit, C\&A, PUMA and the North Face. Consumers are asked to drop of their used textiles with one of the partners in their in-store collection bin, and receive a voucher with which they can immediately get money off a new purchase in exchange (I:CO 2013).

As mentioned, the sorting of textiles is usually done by hand, but EUfunded initiative Textiles4Textiles has created an automatic sorting installation which will be able to sort used textile material according to fibre composition and colour. In theory, this will guarantee buyers of sorted textiles a constant quality in terms of composition regardless of the sorting plant they buy from and when they buy (Textiles4Textiles 2013).

Intermediaries called "pickers" and expert buyers travel between large textile warehouses and select garments with particular appeal to, for example, domestic youth markets, special period markets such as retro and vintage, and niche markets in e.g. Japan (Hansen 2006).

\subsection{Global trade patterns of used textiles}

The global trade in used textiles has expanded hugely in both its economic power and global scope. The estimated value of the global trade in second-hand garments has almost doubled in just half a decade from USD 2.02 bn in 2007 to USD 3.65 bn in 2012 (UN 2013), but since these 
statistics are based on declared exports and imports the true volumes and values being traded are likely to be higher (Norris 2012b).

Used textiles ${ }^{17}$ are mostly exported from the wealthier countries of Europe and in North-America. In 2012 the United States was the world's largest exporter in terms of value, followed by the United Kingdom, Germany, rep. of Korea and the Netherlands (UN 2013). The better graded used clothes collected in North-America are mostly exported to Central American Countries and the lower graded clothing is shipped to Eastern Europe, Africa and Asia (Hansen 2006). In 2012 EU-27 imported close to $89 \mathrm{~m}$ tonnes of used textiles worth of USD $107 \mathrm{~m}$., whilst exporting $1.15 \mathrm{bn}$. tonnes of used textile worth USD $1.44 \mathrm{bn}$. (UN 2013). Textiles collected in Europe are exported to Pakistan, Poland, the Netherlands, Ukraine and Tunisia (Eurostat 2013).

The trade in used clothing represents only a small proportion of the total global trade in clothing, but for many sub-Saharan African countries it is a dominant feature of the clothing market (more than $30 \%$ of the total value of imports and much more than $50 \%$ in terms of volume) (Baden \& Barber 2005). Largest world importers of used textiles are the Russian Federation, Pakistan, Malaysia, Ukraine and Canada (UN 2013).Due to national interests of varying kind, exporters of used clothing and textile products face numerous restrictions and requirements such as import bans, requirements for fumigation, proof of sanitation etc. when products are being shipped to foreign markets. A review by the ITA found that more than 30 countries have imposed some kind of restriction and/or ban for imports on used clothing (ITA 2013). These countries are mainly African, Asian or South American countries who introduce these bans in order to try to protect their local textile productions, and for health and sanitary reasons. Some countries allow only for imports of used clothing if they are donations.

\subsection{Global recycling of used textiles}

As mentioned the market for used textiles in North America is large and flourishing. Even though the United States is the world's largest exporter of used textiles Canada is also an important player. Since the turn of the

\footnotetext{
17 In this context we use the broad term "used textiles" to cover the HS-definition in the UN's Comtrade database "Worn clothing and other worn articles" (HS as reported 630900).
} 
millennium, many now consider Toronto to be the world's used clothes capital with numerous sorters and recyclers. However, like in Europe, the recycling business here is also struggling, as margins are subject to "major pressure" in North America, with some business closures anticipated in Canada (BIR 2013a).

In general the recycling facilities located outside Europe and North America appear to be more profitable. One explanation could be that the wages are significantly lower. In return the quality, and thus the sales value of the output from the recyclers is also perceived to be lower, than the output produced by EU recyclers.

Panipat in north India is now the world's largest textile recycling hub, which sources its materials from the international used clothing market. Panipat has over 300 mills producing shoddy ("regenerated") yarn from recycled fibres, which is woven into poor quality cloth and blankets for the domestic market (85\%) and for export (15\%). Panipat supplies over $90 \%$ of the shoddy-wool relief blankets bought by international aid agencies for use in global disasters (Norris 2012b).

The import to India are not always damaged or low-quality textiles as is usually assumed and/or claimed, but unsurprisingly they include textiles for which no more profitable market can be found by commercial rag dealers. Textile recyclers try hard to establish niche markets, and report that recycling grades make little profit, but save them the cost of the material (ibid). In fact, much of the feedstock in Panipat factories is wearable winter clothing for which there is little demand in developing economies with hotter climates. Undamaged, reusable coats, jackets, jumpers, and children's clothing made from mixed fibres and wool are systematically slashed ("mutilated") before crossing the Indian border to conform to tariff requirements, then manually cut up into small pieces by women using vegetable cutters, and mechanically torn to shreds for fibre reclamation (ibid).

Chemical recycling is an alternative option to the mechanical recycling and Japanese Teijin which is one of the leading material producers in Japan, has established a recycling system, named Eco Circle, for polyester produced and sold by the Teijin. As of 2011 they have more than 150 members both within and outside of Japan (Tojo et al., 2012). The collected pure polyester products go through chemical recycling process and become the material with the same quality as virgin materials produced from oil. There also appears to be a relatively large market for rags cut from used textiles, most commonly used for industrial purposes. 


\section{Summary of main drivers and barriers for development of markets for used textiles}

Used textiles have increasingly become a global trade commodity. The estimated value of the global trade in used clothing for example has almost doubled in just half a decade from USD 2.02 bn in 2007 to USD 3.65 bn in 2012. The main source of the "raw materials" for this burgeoning trade are the wealthy countries of North America and Europe. EU-27 officially exported $1.15 \mathrm{bn}$. tonnes of used textiles worth USD $1.44 \mathrm{bn}$ while importing only 89 million tonnes in 2012. The true volumes of trade are likely to be higher.

The trade in used clothing represents only a small proportion of the total global trade in clothing. However, for some developing countries it is a dominant feature of the clothing market representing more than $50 \%$ of the total trade in clothing by volume. The used clothing economy links the developed and the developing parts of the world via an integrated and complex market. The market is not only beneficial for the environment but it also serves as a valuable resource for developing local livelihoods in the developing world.

This increasingly global demand for used textiles from Europe has also a strong influence in the Nordic countries, with the majority of separately collected used textiles exported for sorting and subsequent reuse and recycling in the rest of Europe and further afield. The collection of used textiles, especially clothing suitable for reuse is well established and flourishing in most Nordic countries, driven mostly by charitable organisations though increasingly by other actors.

Nevertheless, there is still a huge loss of potentially useful used textiles in Nordic countries. The share of textiles put on the market which eventually ends up in separately collected streams of used textiles range between $20 \%$ in Sweden to $45 \%$ in Denmark. The remainder indicates the upper limit of the proportion which ends in incineration and landfill. This represents a significant loss of useful products and materials. 
While there are strong drivers for the collection/reuse/recycling of used textiles in the Nordic countries there are also a number of barriers. These have been described in detail in this document and are summarised below.

\subsection{Main drivers}

In addition to the main meso-level driver of the global demand for used textiles, there are a number of additional drivers operating in Nordic countries.

\subsubsection{Higher prices for Nordic textiles}

The prices for textiles collected on the Danish market appear to be relatively high compared to the European average. This is probably a result of greater wealth in Denmark and thus a higher purchase and turnover of higher quality textiles. This is also likely to be true in the other Nordic countries.

\subsubsection{Growth in the demand for second hand clothing}

Like elsewhere the Nordic countries have generally seen a growth in the demand for second-hand and vintage clothing perhaps initially driven by the falling consumer confidence following the financial crisis but later reinforced by reuse and vintage becoming fashionable. Growth of more than $20 \%$ was reported by some actors between 2011 and 2012. On the other hand the supply of used clothing to second hand shops is reported to have decreased, due perhaps to increased private sale of used clothing and a lower willingness to get rid of clothes that citizens may have a use for later.

\subsubsection{Increasing political interest}

Making better use of used textiles both in an environmental and economic perspective has moved higher up the policy agenda in some Nordic countries. This group of textile related projects for the Nordic Council are evidence of that. So far however, this has not resulted in much in the way of legislative change specific to textiles. There is currently no requirement for separate collection of textiles in Nordic countries although a handful of municipalities do offer this. This may change following the development of waste prevention strategies and programmes in 
Nordic countries which are required under the EU Waste Framework Directive (WFD) by the end of 2013. The recent Norwegian Waste Strategy focuses on dialogue with actors in the collection, reuse and recycling chain to identify challenges and possible measures.

The 50\% recycling target of municipal solid waste (MSW) by 2016, set by WFD may also be an indirect driver. However, it isn't clear on the extent to which countries will focus on textiles in the implementation of this since they don't represent a large share by volume of municipal waste. The Landfill Directive is also an indirect driver. Implementing legislation which comes into force in Finland after 2016 will effectively ban all textile wastes from landfill.

\subsubsection{Willingness of consumers to separate textiles in waste}

In Finland at least, citizens' attitudes towards textile waste sorting and re-use, is positive with a majority stating they are willing to separate non reusable textile waste from mixed waste. Similarly surveys haven't been found in other countries. The increasing awareness of younger generations in particular has been raised by a number of social innovations in Nordic countries such as swap markets. In addition, the activities of some high street clothing stores in collecting clothing for reuse/recycling has also raised awareness among consumers.

\subsubsection{Increasing quantities of textiles}

The purchase of new textiles is also increasing in some countries e.g. Sweden increasing the quantities potentially available for collection and reuse/recycling and improving the economies of scale. However, since much of this increase may be a result of the trend in fast fashion, the quality of the resulting used textiles may be reducing. 


\subsection{Main barriers}

These drivers are countered by a number of obstacles to increasing collection and reuse/recycling. These can be summarised as follows.

\subsubsection{Lack of coherent rules for collecting organisations}

In all the Nordic countries the majority of the collection operations are carried out by charitable organisations but private actors are increasingly becoming involved. Organisations tend to collect via containers, for which in general permission is required from the municipality or the landowner for private land. However, in some countries there is lack of coherence on who has the responsibility for granting permission to collect textiles.

In Denmark state guidelines suggest that collecting companies must be charities or have a partnership with a charity. Similarly, in Sweden municipalities often ask for a so called "90 account" from the collector which is an account that only charitable organisations can obtain. In Norway any organisation can apply for permission to put up containers but those claiming charitable status must provide externally verified assurance that the money raised is being applied to charitable work.

A lack of control of permits as well as the lack of sanctions in case of missing permits is also a problem in some countries. This results in illegal textile containers, a lack of transparency of material flows and to some extent to a distorted market.

\subsubsection{The competition is increasing as prices rise and the market diversifies}

In most Nordic countries the market is diverse and the number of actors growing. A limited but growing number of clothing high street chains brands are beginning to carry out collection of used textiles in their stores in response to calls for a more sustainable fashion industry, often in partnership with a textile collecting organisation and/or company. In some countries (e.g. DK, NO), however, this has been inhibited somewhat by disadvantageous conditions for private operators with respect to VAT rules and differential treatment with respect to setting up of collection containers, but is nevertheless still occurring.

While this may in general be a positive trend, a growth in illegal operations is being reported in several countries. This includes doorstep collections by non-registered organisations or direct theft of donated 
textiles from containers or other drop-off points. Estimations of losses due to illegal activities range between $4 \%$ in Sweden to $10 \%$ in Norway.

In addition many of the new actors have little knowledge of markets and are not handling used textiles in accordance with the waste hierarchy.

\subsubsection{High wages exclude most sorting operations in Nordic countries}

The majority of the textiles collected by organisations in Nordic countries is exported for further sorting and subsequent handling in other European countries. This is primarily because the wage that would be necessary to obtain Nordic workers with the necessary high skill level cannot be justified by the prices for the sorted fractions. The sorting that does occur in Nordic countries generally relies on voluntary unskilled or poorly trained labour. As a result textiles might not be explored fully according to the prices in the market and/or according to the waste hierarchy.

\subsubsection{Definition of used textiles as waste can hinder markets}

Although there are exemptions under differing complex conditions, in general used textiles are considered to be waste. As such they are officially owned by the relevant municipality who must therefore give special permission to organisations who wish to collect and sell this "waste". In some countries the act of actively donating textiles to an organisation excludes the articles as being considered as waste. However, even in these countries the waste definition rulings present a potential obstacle to waste management organisations wishing to sort textiles waste from other municipal wastes for resale for recycling.

Clear end-of-waste criteria for textiles for application in Nordic countries would make operations simpler for collecting organisations. A proliferation of different rules and regulations in general across the EU means that it is also difficult to make coordinated systems work on a European scale. Clarification of common European end-of-waste criteria for textiles hasn't been planned in the near future.

\subsubsection{VAT rulings are problematic}

In Denmark for example charity organisations are exempt from paying VAT while private collectors must operate under normal business conditions. Luxury second-hand retailers have to pay output VAT, but since they can't refund any input VAT they face some difficult market condi- 
tions. In Norway sales of used products in second hand shops run by charity organisations are exempted from VAT. However, profit must go to a charitable purpose, the products in the shop must have been donated free of charge and the workers must be voluntary, unpaid labour. One of the major charitable collectors in Norway, Fretex must also pay VAT due to its status as a corporation.

Finally, in a number of countries, high street chains face obstacles in donating faulty or returned textiles to charities due to the fact that they can't reclaim VAT from donated unused textiles.

\subsubsection{Non-reusable textiles are still not being collected due to a lack of domestic market}

The majority of the separately collected used textiles comprises clothing that is suitable for reuse. The focus on separate collection of household textiles has been less strong, and collection of used textiles that are not suitable for reuse even weaker. With respect to the latter most collection organisations actively dissuade citizens from donating textiles that are not suitable for reuse.

This is partly due to a lack of domestic recycling capacity (see below). While there is a market for recycling in Europe, prices are low. Far from being a possible money earner for organisations, it typically costs organisations money to send textile waste only for recycling in other European countries.

Incineration of non-reusable textiles also costs money for most collecting organisations, although charities can be exempted from these costs under certain conditions in Sweden and Denmark. Incineration fees are not a strong driver for recycling since the fees are often similar to the cost of transportation of low quality textiles for recycling in Europe. In this case incineration is most often chosen as "the easy option". This may in part be due to lack of knowledge of markets. Where recycling of Nordic collected textiles does occur it is limited to that fraction of mixed quality textiles that are exported for sorting in other countries. In that case it can make economic sense for the sorting organisations to sell the unusable fraction to recyclers. 


\subsubsection{Very few companies in Nordic countries recycling textile waste}

Only a few examples of companies recycling textile wastes were found in Nordic countries. Some recycling facilities have closed down in recent years due to difficult economic conditions including the high costs of labour. This lack of a Nordic market for non-reusable textiles is a significant barrier to collection of these textiles. The two main recycling organisations identified, both in Finland, report an opposite situation where they can't obtain a sufficient supply of suitable material for recycling. They can't compete on price for separately collected reusable textiles and most non-reusable textiles of suitable quality end in mixed municipal waste.

The problem is a classic chicken and egg scenario: A lack of large quantities of separately collected textiles suitable for recycling challenges the economies of scale of potential recycling facilities. A lack of local market for recyclable textiles removes any economic motivation for collecting them.

\subsubsection{Most recycling taking place in Europe is downcycling}

A recycling market does exist in Europe and much of the non-reusable textiles that are included in unsorted mixed textiles that are exported from the Nordic countries for sorting and subsequent handling in Germany or the Netherlands for example are recycled. However, this mostly comprises downcycling with uses such as cutting into rags, filing for carseats, insulation etc. This significantly reduced the environmental benefits gained by recycling compared to incineration with energy recovery.

A few mechanical and chemical processes for recycling of fibres have been developed and are in use with the aim of creating new fibres, but there are still obstacles to overcome before these technologies can be implemented on a wider scale. Due to this yet immature market for recycling, the market price for textiles that can be reused is typically far higher than the price for textile waste for recycling. There is a small market for recycling of pure polyester but the European market for cotton and blended fibres that can't be recycled mostly comprises the downcycling options mentioned above 


\subsubsection{European recyclers find it hard to make ends meet}

An increasing numbers of actors are competing for the supply of used textiles in Europe and the prices for second-hand used clothes have tripled in the past five years. Recyclers report having difficulties in breaking even since their purchase price is high and increasing, compared to the price they can obtain for their sorted/recycled material outputs.

Recycling facilities located outside Europe and North America appear to be more profitable. One explanation could be that the wages are significantly lower. In return the quality and the sales value of the output from the recyclers are also perceived to be lower. 


\section{References}

Aalto, K. (2013). Personal communication. National consumer research centre.

Affaldsbekendtgørelsen: Kapitel 8 - Principper for kommunalbestyrelsens fastsættelse og opkrævning af gebyrer https://www.retsinformation.dk/forms/ R0710.aspx?id=144826\#Kap8

Ahonen, T. (2012). Poistotekstiilien hyödyntäminen. Kyselytutkimus asenteista ja mielipiteistä liittyen tekstiilien hyötykäyttöön. Ammattikorkeakoulun opinnäytetyö. Kestävän kehityksen koulutusohjelma. Hämeen ammattikorkeakoulu.

Avfall Norge (2012). Notat innsamling og gjenvinning av tekstiler. http://www.avfallnorge.no/stortingsmeldingen2012.cfm?pArticleId= 24926\&pArticleCollectionId=3

Baden, S. \& Barber, C. (2005). The impact of the second-hand clothing trade on developing countries, Oxfam, http://policy-practice.oxfam.org.uk/publications/ the-impact-of-the-second-hand-clothing-trade-on-developing-countries-112464

BIR (2012). Textiles Division: Margins under pressure as originals prices soar, Press Release 02 November 2012, Brussels, http://www.bir.org/assets/PressReleases/ 434PostBarcelonaTextiles.pdf

BIR (2013). Textiles, http://www.bir.org/industry/textiles/

BIR (2013a). Textiles Division: Pressure mounts as prices of originals reach "a zenith", Press Release 05 June 2013, Brussels, http://www.bir.org/assets/PressReleases/ 453PostShanghaiTextiles.pdf

Dagens Næringsliv (2013). Fra shoppelykke til shoppestopp. Newspaper article in Dagens Næringsliv. http://www.dn.no/privatokonomi/article2600958.ece

Dahlin, Elisabeth. (2013). "Swedish market for collection, reuse and recycling of used textiles - Swedish Red Cross" telephone interview. IVL.

Dansk Mode og Tekstil (2012). Grønne kunder går efter genbrugstøj, 2nd November 2012, http://www.dmogt.dk/Nyheder/GroenneKunderGaarEfterGenbrugstoej.aspx

Danish EPA (forthcoming). Fremme af affaldsforebyggelse og øget genanvendelse $i$ tekstilbranchen, Unpublished report by the Danish EPA.

Danish EPA (2013). Dialogue meeting number III, Fremme af affaldsforebyggelse og øget genanvendelse i tekstilbranchen, 23rd January 2013.

Danish EPA (2013b). Grønlistet affald - B3030 Tekstilaffald, http://www3.mst.dk/ jordogaffaldvejledninger/grontlistet-affald/GetGuidance?id=352

Dantextil (2013). Personal communication with Peter Albertsen, July 2013.

Drammens Tidende (2011). Gammelt og brukt er godt som gull. Newspaper article. http://dt.no/nyheter/gammelt-og-brukt-er-godt-som-gull-1.6655488

Enebog, Emma. 2013. "Swedish market for collection, reuse and recycling of used textiles - Myrorna" telephone interview. IVL.

EUWID (2012). The waste textiles market in Germany, EUWID Recycling and Waste Management Issue 20/2012 of 04.10.2012.

EUWID (2013). The waste textiles market in Germany, EUWID Recycling and Waste Management Issue 3/2013 of 06.02.2013. 
EUWID (2013a). The waste textiles market in Germany, EUWID Recycling and Waste Management Issue 7/2013 of 04.04.2013.

EUWID (2013b). The waste textiles market in Germany, EUWID Recycling and Waste Management Issue 12/2013 of 12.06.2013.

EUWID (2013c). The waste textiles market in Germany, EUWID Recycling and Waste Management Issue 15/2013 of 24.07.2013.

Financial Times (2012). Prices for second-hand UK clothes soar, O'Connor, Sarah, April 20, 2012, Financial Times, http://www.ft.com/cms/s/0/ 44784f66-8ae8-11e1-912d-00144feab49a.html\#axzz2YRWPXKhC

Finansdepartementet, 2008: Skriftlig spørsmål nr. 905 fra stortingsrepresentant Ingebrigt S. Sørfonn av 4. april 2008. http://www.regjeringen.no/nb/dep/fin/dok/ andre/brev/brev_stortinget/2008/svar-pa-spm-905-fra-stortingsrepresentan. html?id=507601

Frelsens Hær (2013). Genbrug med hjertet, https://www.frelsenshaer.dk/index.php?page=genbrug

Fretex (2012). Årsrapport, Fretex.

Granum, C. R. (2013). Klær til overs. En undersøkelse av hva som skjer med overflødige tekstiler fra norske kleskjeder. Framtiden i våre hender. Rapport 1, 2013.

Hansen, C. S. (2011). Affaldsgebyr otte gange så højt i hovedstaden som i Jylland, 13 April 2011 in Berlingske Business, http://www.business.dk/oekonomi/ affaldsgebyr-otte-gange-saa-hoejt-i-hovedstaden-som-i-jylland

Hansen, K. (2006). Secondhand Clothing, Berg Encyclopedia of World Dress and Fashion, Volume 10 - Global Perspectives, Part 4: Fashion Worldwide http://www.bergfashionlibrary.com/staticfiles/Encyclopedia/ Secondhand-Clothing-Global-Fashion.pdf

Hinkkala, H. 2011. Tekstiilikierätyksen esiselvitys - Poistotekstiilimassojen hyödyntämistapojen edistäminen jätehierarkian mukaisesti. VELOG - Vetovoimaa logistiikalla Forssan seudulle -projekti. Hämeen ammattikorkeakoulu. Pitääkö kääntää tähän?

Hintikka, U. (2013). Personal communication. Jykatuote.

Hove, E. (2013). Personal communication, Danish Red Cross.

Huopalainen, M. 2013. Personal communication. UFF.

I:CO (2013). About I:CO, http://www.ico-spirit.com/en/about-ico/

Ideell Second Hand. 2012. Survey results 2012 [Enkätredovisning 2012]. Ideell Second Hand.

ITA (2013). Worn (used) clothing and textiles products, International Trade Association - Department of Commerce, United States of America, http://web.ita.doc.gov/ tacgi/eamain.nsf/b6575252c552e8e28525645000577bdd/ 401dbca37c2d025985256efb0068f875?OpenDocument

Jansen, André A. A. (2013). "Recycling of used textiles by KICI" personal communication. IVL.

Laitala, K., Klepp, I. G., Morley, N., Meistad, T., Chapman, A., Chen, W., Hebrok, M. Daae, J. and Augustulen M. H (2012). Potensiale for økt materialgjenvinning av tekstilavfall og andre avfallstyper (papir/papp, metall og glass). Fagrapport nr. 2-2012 Rev. 1. SIFO, 2012.

Letsrecycle (2012). Textiles market "becoming increasingly difficult", 9 November 2012, letsrecycle.com http://www.letsrecycle.com/news/latest-news/ textiles/textiles-market-2018becoming-increasingly-difficult2019

Letsrecycle (2013). Textile prices 2013, letsrecycle.com http://www.letsrecycle.com/ prices/textiles/textile-prices-2013 
Letsrecycle (2013a). Six textile recyclers close "with more to come", letsrecycle.com, June 122013 http://www.letsrecycle.com/news/latest-news/textiles/ six-textile-recyclers-cease-trading-2018with-more-to-come2019

Lium, A.-G. and Bremnes, H. (2007). Fra gamle klær til nye produkter. Rapport 0705 Møreforskning.

Metsärinne, V. 2013. Tasalaatuisen tekstiilijätteen kierrätysmahdollisuudet.

Min Mote (2013). Jenny Skavlands shoppestopp-tips. Article in the magazine Min Mote. http://minmote.no/2013/01/ jenny-skavlans-\%C2\%ABshoppestopp\%C2\%BB-tips/

Momsloven (2013). Fritagelser Momsloven §13, stk. 19 https://www.retsinformation.dk/Forms/R0710.aspx?id=17030

Norris, L. (2012a). Trade and Transformations of Second-Hand Clothing: Introduction, Textile, Volume 10, Issue 2, pp. 128-143, http://www.ingentaconnect.com/ content/bloomsbury/tjcc/2012/00000010/00000002

Norris, L. (2012b). Recycling imported secondhand textiles in the shoddy mills in Panipat, India: an overview of the industry, its local impact and implications for the UK trade, A research summary by Lucy Norris, Department of Anthropology, UCL, February 22, 2012, http://www.wornclothing.co.uk/wp-content/uploads/2011/01/ SummaryShoddy.pdf

Norwegian Customs, (2013). http://www.toll.no/templates_TAD/Tolltariffen/ Chapter.aspx?id=262998\&epslanguage $=$ no\&bk=63.09\#63.09

Norwegian Ministry of the Environment (2013). National waste strategy. Strategi, Avfall, Fra avfall til ressurs, 2013.

NOU (2002). http://www.regjeringen.no/nb/dep/md/dok/nou-er/2002/ nou-2002-19/11/7.html?id=368735

Pihl, K. (2013). Personal communication, UFF Denmark.

Ramboll (2012). Når avfall blir butikk. Rambøll 2012. Commissioned by Avfall Norge.

Rintsch, 0. (2008). Hope in a downward Market, Recycling Magazine no. 01:08, http://www.recyclingmagazin.de/epaper/rm0020/default.asp?ID=16

Rosinski, Klaus (2013). "Swedish market for collection, reuse and recycling of used textiles -Human Bridge" telephone interview. IVL.

Røde Kors (2013): Genbrug, http://www.rodekors.dk/det+gor+vi/genbrug

Rønn-Simonsen (2013). Personal communication, Kirkens Korshaer.

SKAT (2013): Skat (2013). Brugtmoms http://www.skat.dk/ SKAT.aspx?oId $=2064614 \& v I d=0$

Skov, L., Larsen, F. \& Netter, S. (2011). Kommissionsgenbrug: imellem nyt og gammelt, Creative Commons, http://openarchive.cbs.dk/bitstream/handle/10398/8280/59-LS FLSN-Kommissionsgenburg_imellem\%20nyt\%20og\%20gammeltx.pdf?sequence=1

SMED. (2011). Mapping of volumes and flows of textile wastes [Kartläggning av mängder och flöden av textilavfall]. SMED Rapport Nr 46 2011. Svenska MiljöEmissions Data.

Søndergaard, B. (2012). Genbrugsbranchen åbner gigantiske markeder, Kristeligt Dagblad, 29. November 2012, http://www.kristeligt-dagblad.dk/artikel/ 488656:Danmark--Genbrugsbranchen-aabner-gigantiske-markeder Textiles4Textiles (2013). What is T4T, http://www.textiles4textiles.eu/?p=what-is-t4t Tiard, L. (2013). The French EPR, Presentation at the Mistra Future Fashion Symposium - Sustainability \& Producer's Responsibility in Textiles, 29th May 2013, Malmö.

Tojo, N., Kogg, B., Kiørboe, N., Kjær, B. and Aalto, K. (2012): Prevention of textile waste - material flows of textiles in three Nordic countries and suggestions on policy in- 
struments, TemaNord 2012:545, Nordic Council of Ministers,

http://www.norden.org/da/publikationer/publikationer/2012-545

UFF (2012). Vuosikertomus 2011. [Annual report 2011, In Finnish].

Utdanningsdirektoratet (2012). Læreplan i valgfaget design og redesign. http://www.udir.no/kl06/DOR1-01/

UN (2013). Comtrade Explorer Statistics, Classification: HS2007, Commodity: 630900 (worn clothing and other articles, Year: 2012, http://comtrade.un.org/ $\mathrm{db} / \mathrm{ce} /$ ceDefault.aspx

Ward, V. (2012). Recession fuels charity shop boom, The Telegraph, 14 May 2012, http://www.telegraph.co.uk/finance/newsbysector/retailandconsumer/9262907/ Recession-fuels-charity-shop-boom.html

Werther, I. (2013). Personal communication. 


\section{Collection and sorting systems}

By David Palm, Helena Dahlbo, Katja Moliis, Haben Tekie 



\section{Introduction}

This report collates available collection and sorting systems for textile both for reuse and recycling. It gives a broad view of what systems are available for a Nordic strategy with key benefits and disadvantages as well as information if they are mostly suited for reuse or recycling purposes.

The collection systems are divided into operational systems and pilots and future possible collection systems. There is in general more information on the operational systems but future systems are included to provide a wider view of what systems that can be used.

The sorting systems are both operational systems and systems under development and with different purposes such as for reuse or recycling or both. More in-depth technical information on some of the sorting technology is found in the report Technological review together with information on recycling technology.

Collection and sorting systems is one of three sub-reports that summarize the work from the first year of the Nordic Council of Ministers project A Nordic strategy for collection, sorting, reuse and recycling of textiles.

The project is one of six that constitute Resource Efficient Recycling of Plastic and Textile Waste, which was launched by the Nordic Waste Group (NWG) as part of the Nordic Prime Ministers' green growth initiative, The Nordic Region - leading in green growth. Read more in the web magazine Green Growth the Nordic Way at www.nordicway.org, or at www.norden.org/greengrowth 



\section{Collection systems}

Identified collection systems are today divided into operational collection systems and those that are at different levels of trials or pilot operations. All systems are described with; collected materials, where they are used, a short description and benefits and disadvantages. The trials and pilot systems are not as well described as operational system since they are not fully developed, but have been included to give a broader picture of systems that are available.

The described systems are on somewhat different levels, where for example the mandatory EPR includes several of the other described systems. There are also some overlaps between systems.

\subsection{Operational collection systems}

\subsubsection{Mandatory extended producer responsibility}

- Collected materials: clothing, linen, footwear.

- Used where: France (since 2006), planned to be implemented in Canada by 2017.

Extended producer responsibility (EPR) is applied for numerous products in various OECD countries, but the only mandatory EPR system for textiles currently in practice is in France. French companies which produce and import clothing, linen and footwear (TLC in France) are since 2006 responsible by law for providing or managing the reuse and recycling of their products at the end of their usage. Companies have two options for managing this in practice: 1) contribute to financing a collection and recycling system approved by the state or 2) set up a collection and recycling system that is approved by the state. The majority of the industry, 93\%, have chosen the first option and are members of Eco TLC, a private non-profit company, which was in 2009 granted rights to be transferred the EPR for the industry until the end of 2013. Eco TLC is for the time being the only organisation accredited by the French public authorities. The members of Eco TLC pay an annual contribution to the company, based on the last year's volume put on the market crossed 
with the size of each item. There are 4 size categories for clothing and linen and 2 for footwear. Rates vary between EUR 0.1 cents to EUR 4.5 cents, being on average EUR 0.5 cents per item. Rates are announced each year, defined to cover for the need of financial supports. To encourage companies to use recycled fibres from post-consumer textile, linen or shoes, all products that contain a proven minimum of $15 \%$ postconsumer recycled fibres can be given a $50 \%$ discount on the contributions (Eco TLC 2013).

Eco TLC has 26,000 collection sites (charities, collection banks and protected booths) across France, marked with the Eco TLC logo. Participation is voluntary for both local authorities and collectors. Around 154,000 tonnes of textiles were collected in 2012. The collected amount has increased approximately 10,000 tonnes per year since 2009. There are 57 Eco TLC eligible sorting facilities in Europe (40 in France). The collected clothes, shoes and linen are sorted as follows: $60-65 \%$ to reuse (mainly in Africa), 25-30\% to recycling (unravelling or rags) and 5-10\% to waste (landfill or incineration) (Tiard 2013).

In 2012 the Eco TLC collected EUR $14 \mathrm{M}$ from their members. The division between the stakeholders were as follows:

- $65 \%$ to support for the sorting industrials.

- $25 \%$ to the local authorities covering services.

- $8 \%$ for taxes, staff, office and outsourced services.

- $2 \%$ for R\&D (selected by a scientific committee to find new outlets and solutions to recycle TLC) (Tiard 2013).

\section{Benefits}

In general, EPR systems are introduced to increase the separate collection and recovery of wastes, to prevent waste production and to promote ecological design and development of products. Benefits from introducing a system such as the French EPR, have included: growing volumes of collected and treated products, job creation and capacity building in the collection, sorting, reuse and recycling chain. Additionally, with the contributions collected from companies the Eco TLC has been able to launch $R \& D$ programs to find new outlets and solutions to recycle TLC (Tiard 2013).

Introduction of a reduced rate for products that contain at least $15 \%$ post-consumer recycled fibres encourages companies to consider this in the design phase and this can be regarded as an example of an upstream feedback loop which can be used by collective EPR systems. 


\section{Disadvantages}

In spite of the incentive for using recycled fibres in the production of new products, development is still needed within the textile manufacturing to design and produce more eco-friendly products that e.g. last longer and hence introduce less waste, are easier to recycle, use recycled materials etc. There is also need for outlets for recycling materials (Tiard 2013).

In general, some EPR systems are criticized for increasing recycling of the products in question, and not encouraging reuse (e.g. WEEEproducts). This concern has come up within discussions around introducing EPR for textiles in e.g. the Nordic countries. However, according to the French statistics (Tiard 2013), this does not seem to be a problem, since the reuse of the collected TLC has grown from 58\% in 2009 to $60 \%$ in 2012. It can be questioned, though, whether the shipment of clothes to African countries or other less developed countries is sustainable.

When the French EPR was launched, the recycling industry expressed their concern on the systems impacts to companies within the textile recycling business. They were worried about the system replacing existing sorting companies with subsidized ones, skewing competition and making people unemployed (Martin 2009). However, no information was found for assessing whether this has happened or not.

\subsubsection{Container collection, provided by charity organizations}

- Collected materials: Primarily reusable textiles (clothes, smaller carpets, home textiles), shoes, bags.

- Used where: Commonly used in all Nordic countries and several European countries.

Collection containers typically located next to super-markets in municipal car parks, at waste collection sites owned by municipalities or at recycling sites. Textiles are then collected and transported to central sorting or bagging locations for either local second hand or exported to sorting companies. This kind of collection gives an average quality of collected textile with less quality than for example in-store collection but higher than recycling center fractions. One reason for differences in quality of collected textiles is the different instructions from different collectors which can confuse the provider of textiles. Collection primarily for local second hand sale only ask for reusable textile, while collection focused on mixed textile export ask for all kinds of textile, including recyclable. Depending on location of the containers there are different 
levels of problems with waste being thrown in the containers and also issues with theft of textiles.

This collection system mainly focuses on consumer clothing and shoes.

\section{Benefits}

Container collection flows are large and it is therefore one of the main collection systems today. It is also far more low cost than kerbside collection while still providing an easily available collection of textiles. It has the flexibility to collect both for reuse and recycling for most textiles up to a certain size.

Collection by charities gives an extra incentive for consumers to engage in the collection also for the benefit of the charity beyond doing an environmental good.

\section{Disadvantages}

There is an issue of theft from container collection, especially when placed in public areas. It is hard to estimate the level of stolen textile since most often containers are not broken but simply emptied. Placement of containers is a key factor for avoiding this.

Large items such as carpets cannot normally be collected in these containers which creates a need for additional collection options.

There is a minor risk that the consumer does not agree with the aim of the local charity and therefore choose not to provide textile to their collection and due to lack of an impartial collector then discards the textiles as bin and sack waste for incineration.

\subsubsection{Container collection, provided by recycling company}

- Collected materials: textiles, clothes, footwear.

- Used where: Central Finland.

Ekocenter JykaTuote is a Finnish textile collection and recycling company operating on a social basis (i.e. providing employment). The company collects 300 tonnes of textile waste from households through containers located in residential areas (16) and at supermarkets (2). The collected textiles are sorted into 1) second-hand clothes that are sold in their shop, 2) clothes donated to charities, 3) textiles used in their own production line, and 4) a waste fraction, which is sent for incineration. The textiles used in their own production line are further sorted into cotton, light cotton, linen, synthetics and wool textiles. The company processes textiles according to the fiber. Cotton textiles are processed into indus- 
trial wipes, while synthetics and wool textiles are treated so that they can be used as flock and materials for felts. Current products include e.g. mats for underground watering, oil absorbent mats, padding for packaging, insulation felt and absorbent cotton.

\section{Benefits}

The collection containers are located in areas where they are easy for people to reach. The textiles need to be clean, but they can be broken, thus only very dirty and permanently stained or otherwise problematic items need to be disposed of in mixed waste. Hence a larger share of textile waste produced in households can be recovered.

The company has control over the whole chain of collecting, sorting and recycling the textiles. They have control of quality of the textiles sorted for the recycling processes. At least in theory it may be possible to adjust the activity from one production line to another according to the quality of the incoming textiles. In practice this depends also on volumes.

The company provides jobs for unemployed people, offering them rehabilitation, motivation to work and at best a stepping stone to real work life. The employment costs are low due to the subsidized employees, but the efficiency of operations is not as high as in companies working on a commercial basis.

\section{Disadvantages}

Operation organized for employment purposes is in the danger of workers changing very often, which in turn means continuous guiding of new employees which can make the sorting inefficient. A great challenge is in motivating the workers and getting them committed to textile waste sorting.

New investments are difficult to finance, since the company does not work for making profit.

\subsubsection{Second hand shop in-store collection, charities and commercial}

- Collected materials: Reusable textiles (mostly clothing) and shoes (and other).

- Used where: Most of the charity organizations in Nordic countries with shops offer this service. Some charities only collect clothing in this way e.g. Kirkens Korshær, DK; Swedish Red Cross. 
Collection over the counter at second hand shops. Depending on the business model only textiles that can be sold on the domestic market are accepted, or in other cases all textiles are accepted and gathered centrally for sorting. The intention is to sell clothing, thus, most of the donated textiles are of good quality and are reusable. However, in some cases due to the difficulties for the consumer to know what can and cannot be reused, clothes are brought in that are not in a condition to be sold, these are sent for recycling.

\section{Benefits}

Besides doing something that is environmentally beneficial, collection by charities gives an extra incentive for consumers to donate clothing as they want to engage in the aims of the charity. This collection system gives customers a choice, of which charity they think should benefit from their donation i.e. if the consumer does not agree with the aim of a certain charity the consumer can choose another one. Further, the collection system is of low cost where the business is run by volunteers and of a higher cost elsewhere. In addition the second hand stores accept clothes from any brand, thus reducing some of the sorting efforts for the consumer.

\section{Disadvantages}

Collection at second hand is not always easily accessible for all consumers because you often need access to a car since second hand stores are often located outside of city centers. Thus, this type of collections is more time consuming and less convenient than e.g. in-store collection by brands (H\&M) or container collection. Another disadvantage is that textiles have to be clean and in good condition in order to be accepted, which means that there are difficulties for the consumer to know what can and cannot be re-sold directly. Thus, it could lead to consumers wrongfully discarding the textiles as bin and sack waste for incineration because it is simply easier than doing the sorting.

\subsubsection{Take back of own brand, resell in own shop}

- Collected materials: Clothing, shoes.

- Used where: Filippa K, Sweden, Boomerang, Sweden, Top Shop, UK.

In this collection system the clothes which are collected are exclusively of the retailer's own brand and are only accepted if suitable for reuse. Consumers bring own brand used clothes back to the brand shop where they receive a voucher (e.g. a $10 \%$ discount on a new garment in the 
store in return for an old Boomerang garment) either for all products or the used collection only.

The different brands collect their own garments and either resells them as vintage, or re-design i.e. cut the used garments to make new products. The intention is to increase reuse and recycling of clothes. The collection is limited to the own brand.

\section{Benefits}

The take back of reusable clothing gives the consumers a sense of circular material flows and prolongs the life of high quality textiles.

The collection shows that the brand produces clothing of a high quality that can be used for a long time and therefor justifies a high price.

\section{Disadvantages}

It is possible that these types of initiatives in a large scale can, by offering vouchers, out-compete second hand shops that solely live on donations from the public. In addition, the voucher can also be an incentive to increase consumption of new textiles since consumers can decide to consume more clothes due to the voucher, thereby reducing the environmental benefit from collecting own brands.

\subsubsection{Collection of own brand polyester products in stores for chemical recycling}

- Collected materials: Polyester clothing.

- Used where: Patagonia, Houdini, Haglöfs and other high end brands.

Companies that are partners of the Eco Circle ${ }^{\mathrm{TM}}$ project collect their own used polyester clothing in the stores where their clothes are sold. The polyester clothing is sent to Teijin in Japan where it is recycled into new polyester fiber. Since the recycling only manages polyester it is crucial that only pure polyester clothing is collected and sent for recycling. The in-store collection is usually done with a collection box which is managed by the store staff. The cost of the polyester recycling can be assumed high since it is mostly high end brands that have chosen this system.

\section{Benefits}

Textile is collected to be recycled into new textile which is very rare. It is also a system where the Eco circle trademark can be seen by the consumer both when leaving clothes for recycling and when buying new clothing and thereby showing the material loop. 


\section{Disadvantages}

Collection for polyester recycling is high cost and the textile flows in this system are at a low level. This collection only covers polyester products and therefor only covers a limited percentage of textiles.

\subsubsection{Private collections}

- Collected materials: Used clothes and textiles.

- Used where: Everywhere.

Many charity and non-profit organizations arrange locally private collections for used clothes and textiles. For example, the Finnish home economics organization, Martha organization, welcomes dry, clean and reusable clothes and textiles in their regional collection campaigns. Some collectors accept also torn textiles and worn out clothes. One actor, the Lions Club, announces the need of items (clothes, shoes, bed linen etc.) in each local collection campaign and the intended destination of these items. Collection typically takes place in a local school; super market etc. where the organization in question holds a temporary, manned reception point for citizens' clothing donations. Collection campaigns are more frequent around Christmas when donations to people of limited means are welcomed.

Collected materials from non-profit organizations' private collections are sorted manually. Reusable clothes are sold at second-hand stores or flea markets in order to collect funds for charity work or donated to people of limited means in the home country or in neighboring areas. In Finland, for example, non-profit organizations' private collection campaigns often aim at sending reusable clothes to the Russian Karelia and the Baltic countries. Non-usable clothes and textiles are sent for recycling, when possible, but also for incineration.

Used clothes are also collected privately by small enterprises. These companies with a limited number of personnel operate by advertising their local collection campaign in a given area. Donations (clothes, shoes, towels and blankets) are welcomed at a given reception point or collected from door-to-door. Advertisements stating the collection time and route are usually delivered into peoples' mail boxes. The destination of these collections is usually Africa or other developing countries. The motive for collection is the proceeds from used clothes sales. Sometimes sorting of used clothes takes place in large European sorting facilities before clothes are sold in developing countries. 


\section{Benefits}

Private campaigns increase local coverage of used clothes and textiles collection. In areas, where there are no container collections or other form of systematic collection, private collection campaigns are typically the most effortless way of recovering used clothes. In door-to-door collections people get out of the need of transporting recyclable clothes and textiles.

In private collections, the quality of the donated clothes and textiles is fairly good, as many people are willing to sort their clothes and textiles when they have the information of the final destination of the donation. Moreover, direct face-to-face contact with the collecting organization, in comparison to unmanned collection, discourages the intentional misuse of the collection, i.e. bringing clearly waste or unintended fractions to the collection.

\section{Disadvantages}

Private collections take place only occasionally and the information of the collection does not necessarily reach all interested citizens. Sometimes, the destination of the donation is not clear. Furthermore, some private collectors' advertisements have led the citizens to believe that the donations are used for charity, even though these colleting companies intent to make profit. Although most private collectors in the Scandinavian countries operate according to rules and the law, there are also some illegal operators. These illegal private collectors harm the reputation of the entire used clothes and textiles collection system.

\subsubsection{Brand Refund system}

- Collected materials: Reusable (mostly) textile.

- Used where: Klättermusen, Sweden.

In-store refund system for a specific brand, where a voucher of EUR 1-10 is given for the purchase of new clothing when a garment is returned to the store. The company can donate the returned item to charity, re-sell it or send it off for recycling. A refund system is a way to further increase the ease of access for consumers to return used clothing. Moreover, it has the advantage of being considered as a fairly "positive" business model, since you get rewarded while doing something good for the environment. Thus, it is an effective way to get consumers to bring back their used textiles. 


\section{Benefits}

A brand refund system provides a positive experience for the consumer by being rewarded for returning clothing and doing an environmental good. Clothing with a deposit will have a value even when it cannot be used anymore which might keep it out of the mixed waste. Returned clothing is of high quality with little contaminants and returned clothes can to some extent be re-sold directly.

\section{Disadvantages}

Textile flows in an own brand refund system is likely to remain low. In the case that all brands would engage in such an activity it would be confusing for the consumer where to return clothing and difficult to return clothing bought from several different brands.

\subsubsection{Reception at recycling centers}

- Collected materials: most products and materials, not only textile.

- Used where: all over Europe.

Recycling centers organized by municipalities receive used products and materials, sometimes repair them and sell reusable products in secondhand shops. The collection can be very different in different cities but common factors are that material is collected at a recycling center and taken care of (cleaned, repaired, sorted) by means of social activities such as work training. Since the collection often receives financial support for social reasons there can be added value to products which otherwise are not generally possibly.

A possible issue of unfair competition is related to this kind of collection where private reuse companies or charities which do not have the same kind of financial support can have difficulties acting on the same market.

\section{Benefits}

Textile normally deemed for recycling or even disposal can with this collection system sometimes be given a prolonged life with subsidized repairs.

Potentially large textile flows due to collection at recycling centers where consumers often dispose of textiles. The collection can provide useful occupation for people that are hard to employ on the regular labor market.

\section{Disadvantages}

The collection can have issues of unfair competition due to public financial support and out compete regular second hand businesses. 


\subsubsection{Material bank (net-service)}

- Collected materials: Textiles and textile residues from production.

- Used where: The system described is in use in Finland.

Material bank (www.mpankki.fi) is an online market place where excess materials are sold from business to business. Textiles and textile residues are one traded category. In the market place, companies with a surplus of textiles or textile residues from production and companies in the need of textiles can notify their material offers and needs. The Material bank is not a collection system, but at best it replaces both collection and sorting of textile residues from industry.

Users of the online platform need to register, and currently the use is limited to business only. So called warrants, i.e. announcements making known the need for certain type of material, are a key element in the system. Excess textiles traded in the system are of good quality. All of the materials can be used as such or recycled. Offered lots can be sold as such or as divided into smaller shares.

Money transfers are made through the platform. The service administration charges a transaction fee of $8 \%$. Materials can be traded for free as well, in which case there is no charge.

\section{Benefits}

The goal of the material bank is to reduce the amount of waste and to find new use for surplus materials. At the same time, the goal is to develop a common solution, which prevents the fragmentation of the recycling industry and the benefits of networking can be exploited. The system can create new business opportunities, as it does not focus on textiles only, but enables companies to develop ideas on combining different excess materials in their production. Other traded categories are wood, cardboard and paper materials, for example.

One key benefit of the Material bank is that companies can compile textile flows large enough to make their operation economically viable. The system operates at low cost and uses open source code. If functioning properly, the system is more cost efficient than separate collection and sorting systems for industry textile residues. Personnel and use of space is avoided. Selling companies, however, need to store their excess textiles until a buyer is found.

\section{Disadvantages}

The use of the system is limited to business only. Consumers cannot sell their used textiles on the platform, as the operators of the system want 
to distinguish the market from online second hand markets. Private consumers are also excluded from buying materials, as companies primarily want to sell their materials to another company. Consumer demand is evaluated to be too small and more sporadic.

\subsubsection{Kerbside collection, demand driven}

- Collected materials: Reusable textiles and shoes.

- Used where: Sweden and other countries.

Collection is done at the kerb at random intervals depending on time of year. A notice is left in the mailbox about one week before collection specifying what day textiles will be collected. The notice specifies what items can be left for collection and to put the clothing in sealed plastic bags.

Not having a fixed day with regular collection intervals gives the collector a degree of freedom to only collect for example at times when winter clothing is being changed for summer clothing and most people go through their wardrobe. It however requires a high level of participation from consumers to make the collected amounts large enough to compensate for the kerbside collection.

The collection system is used in Sweden by illegal/grey market players with unknown collected amounts. It is however more common in non-Nordic countries.

\section{Benefits}

The collection is one of the most easily accessible since consumers get clothing collected at the kerb, most often when needed.

\section{Disadvantages}

Costly collection with a high risk of having an extensive transport effort for small amounts of textiles. 


\subsection{Pilots and future possible collection systems}

\subsubsection{Recycling center fraction}

- Collected materials: Primarily non-reusable textiles.

- Used where: Stockholm, Sweden (pilot project).

Collection of primarily non-reusable textiles as a separate textile fraction at the municipal recycling center (as for wood waste, electrical waste, plastics etc.). In addition to charity container collection of reusable textiles a container is placed for recyclable textiles waste, carpets and all other products only consisting of textile not suitable for reuse. The collected fraction is then exported to sorters where reusable, recyclable and waste is separated. There is still a reusable fraction from the collection due to the difficulties for the consumer to know what can and cannot be reused.

The collection system has a very high capacity and is cost effective for the operator. It however needs a somewhat different treatment than other waste fractions, with the main being that the textile needs to be protected from moisture and dirt.

\section{Benefits}

Large capacity and cheap collection are the two main benefits of this system. Recycling centers also offers protection from theft of textiles. The contamination levels are reasonably low due to some monitoring by recycling center staff and the easy availability for other wastes to be sorted in other containers. It can collect all kinds of textiles in a mixed fraction, although this was not tested in Stockholm.

\section{Disadvantages}

Collection at recycling centers is not easily accessible for all consumers due to the fact that you often need access to a car and that they are located outside of city centers. If textiles are not collected in a mixed fraction, there is also a difficulty for the consumer to know how to sort their textiles.

Collection of textiles differs somewhat from collection of other wastes (e.g. closed bags instead of opened bags) and this might be an issue both for staff and consumers visiting the recycling center. 


\subsubsection{Kerbside collection, as part of regular waste collection}

- Collected materials: Textiles.

- Used where: London Borough of Bexley, UK, Borås, Sweden and Karlstad, Sweden.

Collection kerbside of mixed textiles. LB Bexley engaged a third sector organization TRAID in 2011 for a free trial collection service to approximately 8,000 households on one collection round. Collection was done once a month and thereby reaching 2,000 households per week. Six cobranded LB Bexley/TRAID bags and a leaflet explaining the scheme were delivered through the letterbox of all households in the area, no less than one week before the first collection. The peak in the collected amount was gained on the third month (WRAP 2013).

In the municipality of Borås the waste company Borås Energi och Miljö together with Borås University conducted trials where "reusable and clean" and "damaged and clean" textiles was collected in the waste room at a large apartment building. The collection was done as for packaging waste for recycling. The first four months of the trial an equivalent of $1.2 \mathrm{~kg}$ of reusable textiles and $0.7 \mathrm{~kg}$ of recyclable textiles per person and year was collected. The effects on reduced textile in the mixed waste are still to be evaluated (Skoglund 2013).

A similar project is performed in the municipality of Karlstad where Myrorna (Charity organization), RagnSells (waste management company) and KBAB (housing company) are collecting textile both for reuse and recycling in separate containers within a number of housing areas. This trial is performed during 2013 and results are still to come (Myrorna 2013).

\section{Benefits}

Potential large collection amounts due to easy participation for consumers. Experience from other kerbside collection shows that the level of contamination is likely low for small houses and higher for apartment buildings. In the LB Bexley case, where a mixed collection of both reusable and recyclable textiles is done, is a preferred option for the consumers since they then don't have to evaluate what can be reused or recycled.

\section{Disadvantages}

Collecting kerbside is a high cost option which requires large amounts of textiles to be economical. There might also be an issue with storage in the home since textile waste is not evenly produced during the year and 
has high volume spikes during "spring cleaning" more suitable for a bring collection system.

Where textiles are to be sorted by the consumer into reusable and recyclable, it can be putting too much work on the consumer and thereby limiting the participation.

\subsubsection{Reception place, where people bring their textiles}

- Collected materials: clothes, home textiles, bags, footwear.

- Used where: Finland, two experiments during 2013.

Two project-based experiments are described here. The first one was organized in spring 2013 in a small town in southern Finland, Humppila. Here consumers were asked to bring all clean and dry textile waste from their homes to the Workshop of the young people (organized by the municipality in order to activate young people that are in danger of being left aside from common working life). The municipality had reserved a depot for the workshop, where textiles were received, sorted and sold or given to co-operating partners. This pilot was run for five months, and all in all 8,000 kilos were sorted during the period (2-4 persons, four hours per day). Sorting was done according to purchase orders given by the cooperating partners, such as Globe Hope Ltd, UFF ry18 and Ekocenter JykaTuote. Some of the textiles were even sold in the second-hand shop put up by the workshop. $70 \%$ of all the textiles were cotton. The quality of textile waste was surprisingly high, including unused items such as e.g. large pieces of fabrics and jackets. Waste fraction delivered to the regional waste management company made up $9 \%$ of the total input.

The second experiment is on-going from June till December 2013 in a small municipality in the Eastern Finland, Varpaisjärvi. The concept is more or less the same as in Humppila, with the exception that the activity is not only targeted for employing young people, but people of all ages being left aside from common working life. The aim of textile sorting is also a bit different from the previous one. The main product of the sorting centre will be material packages that are developed according to the needs of companies, kindergartens, schools and/or other educational institutions. Besides this there will be material and other necessity

18 a Finnish suffix for a registered non-profit organization. 
packages made for individual customers. The possibilities for the material sorting center to serve for storage operations are developed.

\section{Benefits}

Both the experiments have been set up for developing employment models within textile recycling. From this point of view they have been successful, during the period of the experiment. It remains to be seen, whether the experiments have longer lasting impacts on activating and motivating the targeted people to working life.

The quality of textiles brought to the first experiment was surprisingly high, and indicates that people have stored both used and unused textiles or fabrics since possibilities for delivering them to material recovery have been in practice non-existing for the last decades.

Efficient sorting resulted in only a small share of textile wastes ending up to disposal. The co-operating organisations could define the type of textiles they wanted, and hence got exactly the material they needed.

\section{Disadvantages}

The first experiment showed that the people doing the sorting need to have basic knowledge about textiles as materials and also of the sorting process. The workers needed a lot of guidance and hence the sorting was slow. Operation organized for employment purposes is in the danger of workers changing very often, which in turn means continuous guiding of new employees which can make the sorting inefficient. A great challenge is in motivating the workers and getting them committed to textile sorting.

\section{Reception at high street clothing chains, cooperation with commercial sorter, recycler, exporter}

- Collected materials: Clothing.

- Used where: H\&M, globally.

Clothing is collected in stores where a voucher that gives discount on new clothing a given for every bag of used textiles collected. Consumers can maximum deliver two bags of clothing per day. The collected textiles are then collected from the stores by a commercial used textile trader. All clothing, regardless of brand, quality or condition is collected and sent to reuse and recycling. By using a commercial trader of used textiles a similar solution can be used globally. This collection system focuses on environmental benefit rather than social benefit although there are elements of charity in the form of profit sharing. 
The collected flows of textiles are after six months collection still small (for H\&M Sweden an equivalent of 70 tonnes annually compared to up to 30,000 tonnes total annual collection for reuse and recycling) but there is a large potential since all clothing can be returned.

\section{Benefits}

Potentially large collection flows with a low level of contamination at a medium collection cost.

Collection in stores gives consumers a sense of circular flows where textile should not be placed in the mixed waste.

Easy accessible collection for the consumer since all clothing can be returned in one place.

\section{Disadvantages}

The collection is medium cost and requires some work from the stores.

There is a rebound effect when returning clothes gives a discount for buying new clothes that can reduce the environmental benefit of the reuse and recycling of the returned clothes.

The collection of non-reusable clothing can be considered illegal in some countries (e.g. Sweden) since it is considered to be waste.

\subsubsection{Reception at high street clothing chains, cooperation with charity}

- Collected materials: Clothes, shoes.

- Used where: Marks\&Spencer (M\&S) shops, UK.

The collection system covers high street clothing chains that either encourage or even offer incentive for their customers to return their used clothing back to the store. Marks \& Spencer have in their efforts to collect and bring down the amounts of textile waste sent to landfill, amongst other things initiated a partnership with the charity organisation Oxfam. Together they have introduced the concept of "shwopping" and two annual one day wardrobe clear-out, where customers that hand in clothes for reuse (in either Marks \& Spencer or in an Oxfam store) receive bonus points which can be exchanged for new purchases in Marks \& Spencer. All collected textiles are handed over to Oxfam who sorts them and either sells them in one of their stores or recycle them at their recycling plant in UK which sorts around 80 tonnes of textiles per week (Morgan 2013). 


\section{Benefits}

Collection flows can potentially be large. There is an incentive to return clothing and the collected clothing is given to charity which can add motivation to return clothing. Textiles returned in a shop generally have a higher quality than for example collection containers.

\section{Disadvantages}

The collection is medium cost and requires some work from the stores.

There is a rebound effect when returning clothes gives a discount for buying new clothes that can reduce the environmental benefit of the reuse and recycling of the returned clothes.

\subsubsection{Kerbside collection, reward demand driven, private collector}

- Collected materials: Reusable textiles.

- Used where: UK.

Collection is done at the kerb and a reward of about EUR 0.5 per $\mathrm{kg}$ of textiles is given for reusable textiles. The collectors advertise locally which advises the public that they can call to arrange a collection on a specific date. The clothing is weighed at the door and payment is made directly. There is also often a choice of giving the payment directly to a charity instead. The collection is only of reusable clothing. (TRA 2013).

\section{Benefits}

Since it is on-demand collection, there is no risk of theft of clothing. The personal contact also ensures clean and reusable clothing. Clearly shows the value of used clothing to the consumer.

\section{Disadvantages}

The profit margin for the collector is very small and with prices of reusable clothing dropping, the collection will be reduced (TRA 2013). Although being payed, there is quit a lot of work for the consumer to call and meet in person compared to other collection systems. 


\subsubsection{Kerbside collection of mixed dry recyclables from households}

- Collected materials: Textiles and recyclables mixed.

- Used where: UK.

Some mixed recycling collection in the UK also include textiles to be put in the recycling bin. These are then manually removed from the mix of recyclables before automated sorting is performed in Material Recovery Facilities (MRF). This has however not been a very successful collection system and few operators allow textiles due to problems with textiles not being sorted outclogging the automated sorting with high maintenance costs as a result. The collected textiles can only be used for recycling due to contamination from other recyclables.

\section{Benefits}

Easy collection for the consumer and no added collection infrastructure needed where mixed recyclable collection occur.

\section{Disadvantages}

Collection with mixed recyclables further reduce the quality of textiles and have potential high costs for disrupted sorting of other recyclables. The collection is not suitable for reusable textiles.

\subsubsection{Collection containers at offices, Marks \& Spencers}

- Collected materials: Clothing, uniforms, corporate work wear and other textiles.

- Used where: UK. ${ }^{19}$

Marks \& Spencer (M\&S) together with Oxfam delivers clothes recycling boxes to offices for a "one day eco drive" as a free service. They also provide marketing materials such as banners and notices. Oxfam then collects the boxes and the collected textiles are reused or recycled. All employees that donate textiles get a voucher at M\&S.

Cooperation is done with BITC which represents a network of 850 companies with 17.8 million employees to ensure wide participation in

${ }^{19} \mathrm{http}: / /$ corporate.marksandspencer.com/page.aspx?pointerid=e773b189d0024e0dabdbbeb0119a019c 
the collection. The collection shares the "Shwopping" concept with the in-store collection performed in M\&S stores.

Possible collected amounts and quality remains to be seen.

\section{Benefits}

The collection campaign has the potential for large amounts of collected textile and might reach consumers than other collection doesn't. The collection cost can be low since offices are targeted rather than separate households. For small contributions, the collection is easily accessible for the consumer but larger amounts might be difficult to bring to the office.

\section{Disadvantages}

The campaign is limited in time and clothes needs to be either stored or reused in other collection systems during other parts of the year.

There is a rebound effect when returning clothes gives a discount for buying new clothes that can reduce the environmental benefit of the reuse and recycling of the returned clothes.

\subsection{Summary of benefits and disadvantages for collection systems}

Table 1 summarises key aspects for the different collection systems. The rating is subjective and loosely defined from "---" for disadvantageous to "+++" for beneficial compared to other collection systems.

\begin{tabular}{|c|c|c|c|c|c|}
\hline System & $\begin{array}{l}\text { Large } \\
\text { collection } \\
\text { flows }\end{array}$ & $\begin{array}{l}\text { Low levels } \\
\text { of conta- } \\
\text { mination }\end{array}$ & $\begin{array}{l}\text { Low cost (for } \\
\text { operator) }\end{array}$ & $\begin{array}{l}\text { Suitable } \\
\text { types of } \\
\text { textiles } \\
\text { collected }\end{array}$ & $\begin{array}{l}\text { Easily } \\
\text { available } \\
\text { for the } \\
\text { consumer }\end{array}$ \\
\hline $\begin{array}{l}\text { Mandatory extended } \\
\text { producer responsibility }\end{array}$ & +++ & + & + & ++ & ++ \\
\hline Container collection, charity & ++ & + & ++ & ++ & ++ \\
\hline $\begin{array}{l}\text { Container collection, } \\
\text { recycling company }\end{array}$ & - & + & + & ++ & ++ \\
\hline $\begin{array}{l}\text { Second hand, in store } \\
\text { collection }\end{array}$ & + & ++ & ++ & + & + \\
\hline $\begin{array}{l}\text { Take back of own brand, } \\
\text { resell in shop }\end{array}$ & - & ++ & +++ & - & ++ \\
\hline
\end{tabular}




\begin{tabular}{|c|c|c|c|c|c|}
\hline System & $\begin{array}{l}\text { Large } \\
\text { collection } \\
\text { flows }\end{array}$ & $\begin{array}{l}\text { Low levels } \\
\text { of conta- } \\
\text { mination }\end{array}$ & $\begin{array}{l}\text { Low cost (for } \\
\text { operator) }\end{array}$ & $\begin{array}{l}\text { Suitable } \\
\text { types of } \\
\text { textiles } \\
\text { collected }\end{array}$ & $\begin{array}{l}\text { Easily } \\
\text { available } \\
\text { for the } \\
\text { consumer }\end{array}$ \\
\hline $\begin{array}{l}\text { Collection of own brand } \\
\text { polyester for chem. rec. }\end{array}$ & - & ++ & - & + & - \\
\hline Private collections & ++ & + & $+/-$ & ++ & ++ \\
\hline Brand refund system & - & +++ & ++ & + & - \\
\hline $\begin{array}{l}\text { Reception at recycling } \\
\text { centers }\end{array}$ & ++ & + & ++ & +++ & + \\
\hline Material Bank (net service) & + & +++ & + & ++ & --- \\
\hline $\begin{array}{l}\text { Kerbside collection, de- } \\
\text { mand driven }\end{array}$ & + & + & + & + & ++ \\
\hline Recycling center fraction & ++ & ++ & ++ & ++ & + \\
\hline $\begin{array}{l}\text { Kerbside collection, regular } \\
\text { waste collection }\end{array}$ & ++ & + & ++ & ++ & +++ \\
\hline $\begin{array}{l}\text { Reception place, where } \\
\text { people bring textiles }\end{array}$ & - & + & ++ & ++ & ++ \\
\hline $\begin{array}{l}\text { Reception at high street } \\
\text { clothing, commercial }\end{array}$ & + & ++ & + & +++ & ++ \\
\hline $\begin{array}{l}\text { Reception at high street } \\
\text { clothing, charity }\end{array}$ & + & ++ & + & +++ & ++ \\
\hline $\begin{array}{l}\text { Kerbside collection, reward } \\
\text { demand driven }\end{array}$ & + & +++ & - & +++ & ++ \\
\hline $\begin{array}{l}\text { Kerbside collection of mixed } \\
\text { dry recyclables }\end{array}$ & - & --- & - & + & +++ \\
\hline $\begin{array}{l}\text { Collection containers at } \\
\text { offices }\end{array}$ & + & ++ & ++ & ++ & + \\
\hline
\end{tabular}





\section{Sorting systems}

Four sorting systems have been evaluated with all systems are described with; sorted materials, where they are used, a short description and benefits and disadvantages. Manual and semi-automated sorting systems are operational while RFID and NIR are still in the development phase for use on used textile.

\subsection{Manual sorting}

- Sorted materials: Collected used clothes and textiles.

- Used where: Everywhere.

Manual sorting is the universal practice in textile recycling. It is also used as preparation for automated sorting processes (NIR or RFID), when clothes that have value in re-use are segregated before automated sorting processes. In some cases manual sorting takes place even before the collected textile lot reaches the sorting facility, i.e. transportation personnel is responsible for presorting the textiles.

At a sorting facility workers empty packed textiles one package by one. In the initial sorting phase non-textile and waste products are removed. Workers go through the collected lot and sort the textiles according to specific sorting criteria of the facility. Sight and sense of touch are used in sorting. The sorting criteria vary from facility to facility depending on the destined end-user of the sorted textiles. Some facilities sort according to the type, colour, and condition of the textile, others identify the fabric or even try to identify the fibre composition.

Typically in manual sorting, the first task is to determine what is still good enough to be reused as such. Reusable clothes are segregated from other clothes, textiles and rags. In the Finnish UFF, for example, this preliminary sorting phase can entail over 10 categories. The number of categories is dependent on demand and varies from time to time. Some of these categories are then sorted further. Reusable clothes in very good condition, still fashionable or clothes having retro value are sorted to be sold in the country of origin or in other European markets, e.g. in second-hand stores. Clothes that are still 
wearable and in good condition are often sorted into a fraction that is given for charity or sold in developing countries. This kind of sorting can entail multiple phases. Products are graded according to their condition, colour, type, season (winter clothing etc.), composition, target group (gender, children etc.), to name a few possible categories. In this second phase, e.g. the Finnish UFF can sort reusable clothes and textiles into more than 16 different categories.

\subsubsection{Benefits}

The quality of the sorted textiles is mainly dependent on the collection system (where, how, and what kind of material is collected), but also the manual sorting process itself affects the quality of the material to be reused or recycled. Sorting is more efficient and more precise the more experienced the worker is. Learning to identify different categories or types of fabrics only by sight and sense of touch may take some time to master. Manual sorting has its best advantages in removing unsuitable fractions and in sorting reusable clothes into different categories that have value on the second-hand markets. Material and fibre recognition on the other hand is more demanding and it is debatable how accurately it works. By sorting the nonreusable textiles according to their fibre composition and color, operators attain a higher sales value.

\subsubsection{Disadvantages}

Manual sorting stands for high costs in high income countries. Many Nordic countries exploit the lower labor costs of Eastern Europe's sorting facilities. Majority of world's used textiles are manually sorted in Asia, where also Nordic operators send un-wearable textiles either directly or through an intermediary. In the low income countries the well-being of workers is more easily neglected. Demanding working conditions, i.e. lack of ventilation, potential exposure to harmful materials and substances etc., are associated with the manual sorting of waste.

In the Nordic region, to operate economically, some manual sorting facilities employ personnel whose salaries include a support from the municipality, state, etc. The flip side of creating work opportunities for the unemployed or unemployable people can be the decrease in efficiency and accuracy of sorting. Due to high labor costs, the fractions most suitable for recycling are in many cases exported outside the 
Nordic region, and work is devoted to sorting the reusable fraction. Difficulties in identifying specific fabrics have resulted in inadequately sorted textiles being used for down-cycling applications rather than recovered as material in applications where use of virgin materials could be displaced.

\subsection{Semi-automated sorting}

- Sorted materials: Collected used clothes and textiles.

- Used where: Everywhere.

Semi-automated sorting operates as manual sorting (see 3.1), only the process includes some automation. Typically, the feeding of textiles is automated and/or sorted textiles are transported with conveyor belts. The sorting itself is manual work. Commonly used are also semiautomated balers which compact sorted fractions automatically before further transportation. Tying off the bales is sometimes done manually. Some sorting facilities use automated textile waste cutting machines for fractions that are sorted and sent for further recycling.

\subsubsection{Benefits}

Automating phases of the sorting process reduces labor requirements and speeds up the time of processing. Physical stress on the workers is lower. In high income countries cost of machinery can be lower than the cost of labor.

\subsubsection{Disadvantages}

Interruptions in the operation of the automated devices, e.g. device failures, hinder and slow done the recycling process occasionally. Automated processes contain a small risk that sorted textiles get dirty on the conveyor belts etc. 


\subsection{RFID sorting}

- Sorted materials: Textiles.

- Used where: Not used for used textile.

RFID is a technology that is in use for textile sorting systems, but mainly for new textiles. A German RFID providing company, GIS, has provided applications for e.g. Peter Hahn, C\&A, Bugatti and Vögele textilies (Kremer 2013). RFID is independent from mechanical changes in the drive system and readers can be placed at every sorting point in the process. The C\&A sorter plant for jeans in Weiterstadt (Germany), has implemented RFID tags and readers. Inside the factory, each hanger drag incorporates a transponder which has a digital ID that is unique to the item of clothing being transported and the corresponding batch. At every branch in the overhead rail, the reader checks the ID number and opens the points if necessary. Mechanical changes to the conveyor system are unimportant, as the garments are recognized at each switch point irrespective of the cycle. The RFID provides a contactless identification method which is resistant to dirt. The readers are robust, maintenance free, and immune to interference; it is possible to install single readers close together without impeding their operation. The reader at C\&A plant allows up to 128 devices to be joined together in one network. This makes it possible for one PC to control a large installation. The reader is suitable for a diverse range of sorting and conveying applications. Reading the transponder is possible without optical contact and can be done through plastic materials. The reader can identify tag data with a transportation velocity of $3 \mathrm{~m}$ per second. Various reading distances and velocities are possible using the most suitable tag for the application. (Wiesmann, GIS)

GIS made a sorting project including RFID technology for textile wastes 12 years ago. As the textile distribution is a very price sensitive business the tags (being quite expensive) were not fixed at each textile but on the hanger system. So the less expensive barcode on the textile was connected with the tag in the transporting and sorter system. Kremer (2013) estimated that the technology has prospects, but the application for textile waste sorting has to be developed. There is no standard information defined for the tag, so it can include information on the textile material etc. At the moment each textile supplier can define data content of the tag himself. The tag can be of various appearance and forms. Tags which remain in textiles after e.g. washing exist: a buttonlike tag and a one with stripes. The RFIDs could be attached to single 
items or to containers, which have been filled by manual sorting. It was estimated that presorting would be necessary if RFID technology was applied for textile wastes. (Kremer 2013).

\subsubsection{Benefits}

The RFID provides a contactless identification method which is resistant to dirt. The readers are robust, maintenance free, and are immune to interference. The reader is suitable for a diverse range of sorting and conveying applications, also for a fast moving conveyor. Reading distances and velocities can be varied by using different types of tags. Reading the transponder is possible without optical contact and can be done through plastic materials.

Automation reduces labor requirements and can make the sorting more efficient and accurate. Physical stress on the workers is lower. In high income countries cost of machinery can be lower than the cost of labor.

\subsubsection{Disadvantages}

The technology is not yet developed for textile waste sorting. The starting point would be that RFID tags are attached to textiles when they are manufactured. The information included in the tags should be standardized so that all data needed for sorting and recycling can be found on each tag. No exact price data was given by the company contacted, but it can be quite costly to equip each textile with RFID.

As in 3.2., automated processes contain a small risk that sorted textiles get dirty if they are moved along conveyor belts etc. 


\subsection{NIR-sorting 20}

- Sorted materials: Textiles.

- Used where: Wieland Textiles, the Netherlands. ${ }^{21}$

In the project Textiles for Textiles (T4T) an automated NIR sorting for textiles has been developed. The sorting is still not fully operational but the aim is to sort textiles depending on fiber composition (both pure and mixed) and color. The sorting is to be used in combination with manual sorting.

The sorting consists of conveyer belts and NIR sensors where the textiles is spread out on a conveyer belt one at a time and analyzed by the sensors that compare the reflection of the fabric with stored signatures and depending on the content the textile is removed automatically from the conveyer into the corresponding fraction. The technology can separate textile into about 300 different fractions but it is currently done into 5-10 fractions.

The NIR technology is not new in itself and has been used for separation of plastics and mixed recyclables for several years. It is the application on textiles that is new and due to the complex blends of fibers and additives that makes the sorting more complex than for recyclables. The sorting separates clothing items from each other but does not separate fibers within a clothing item and the pure fiber outputs are therefore limited to consisting of the clothing made from only one fiber.

\subsubsection{Benefits}

The NIR-sorting has the capability to remove some of the manual sorting and reducing the cost of large scale sorting mainly for recycling. It can have a high capacity and provide more manageable textile fractions for recyclers than a mixed textile flow.

\footnotetext{
${ }^{20} \mathrm{~A}$ study visit to this facility is being planned and more information may become available.

$21 \mathrm{http}: / /$ textiles4textiles.eu/
} 


\subsubsection{Disadvantages}

To be cost efficient, a NIR-sorting needs to have high volumes of textiles due to the investment cost being very high. Due to the complexity and diversity of textile fibers there is a need for many fractions which add to the investment cost.

\subsection{Summary of benefits and disadvantages for sorting systems}

Table 2 summarises key aspects for the different sorting systems. The rating is subjective and loosely defined from "---" for disadvantageous to "+++" for beneficial compared to other sorting systems. The RFID and NIR sorting are potentially very low cost per kg of sorted textile, but require very large flows for this to be achieved.

\begin{tabular}{|c|c|c|c|c|c|}
\hline System & Large capacity & $\begin{array}{l}\text { Low conta- } \\
\text { mination }\end{array}$ & Low cost & Flexibility & Availability \\
\hline Manual sorting & + & ++ & -- & + & ++ \\
\hline $\begin{array}{l}\text { Semi-automated } \\
\text { sorting }\end{array}$ & ++ & ++ & + & + & ++ \\
\hline RFID sorting & +++ & $+?$ & ---* & ++ & -- \\
\hline NIR-sorting & ++ & $+?$ & -.-** & + & - \\
\hline
\end{tabular}

* requires very large flows to be cost efficient. 



\section{Conclusions and recommendations}

Collection systems with a capacity for large textile flows have in general a higher contamination levels in the collected textiles. This is likely due to little manual involvement in collection which makes collection cost efficient, but may cause issues later in the value chain.

The collection systems Mandatory EPR, kerbside collection as part of regular waste collection and container collection are the only collection systems which combine the possibility for large collection flows with convenience for the consumers.

The system of a mandatory EPR fulfills most requirements for a collection system, likely because it combines several of the different collection systems in a joint effort. A mandatory EPR may however have a high risk of contaminations in the collection and can potentially have a high total cost for collection.

There are a large number of new collection systems on trial in various stages which makes a definite conclusion difficult. The scenarios to be chosen further on in the project will likely include several different aspects of collection. With regard to the sorting systems, there will likely be manual and semi-automated sorting also in the future but with further refinement of especially the NIR sorting, we might see a shift in the coming years. 



\section{References}

Eco TLC (2013). http://www.ecotlc.fr/page-297-information-in-english.html Kremer, K. (2013). GIS. Personal communication by email on 2013-09-30.

Martin, I. (2009). French eco-levy stirs strong emotions. BIR Amsterdam, November 2009, p. 35. http://www.recyclinginternational.com/magazine/issue-november2009/article/2081/bir-amsterdam-bir-amsterdam-textiles-french-eco-levy-stirsstrong-emotions

Myrorna (2013). http://www.mynewsdesk.com/se/myrorna/pressreleases/ fastighetsnaera-textilinsamling-testas-i-samarbete-mellan-ragn-sells-myrornaoch-kbab-857096

Skoglund H (2013). Personal communication by email on 2013-10-04.

Tiard, L. (2013). The French EPR. Presentation at the MISTRA Future Fashion Symposium on Sustainability and Producer Responsibility in Textiles, Malmö 29.5.2013. http://www.mistrafuturefashion.com/en/media/news/Documents/ Laurianne\%20Tiard\%2029\%20May\%202013.pdf

TRA (2013). Personal communication with Alan Wheeler, director of Textile Recycling Association UK. 2013-11-08.

WRAP (2013). http://www.wrap.org.uk/content/textile-collection-guide 



\section{Technology review of sorting and recycling of textiles}

By: Clara Valente, Kari-Anne Lyng, David Palm, Tomas Rydberg 



\section{Introduction}

In the last decades, the growth of population and the use of garments have increased steadily, leading to large amounts of waste. Consequentially, it becomes more and more important to develop adequate systems for sorting and recycling of textiles.

Recycling of textile involves converting what is considered as waste into a new product. According to Pesnel and Perwuelz (2013) recycling processes may be characterised either based on the techniques in use (chemical or mechanical e.g.) or on the type of waste (natural: cotton or synthetic: polyester and form: fibres or fabric).

According to the Bureau of International Recycling (BIR 2013), the whole recycling process includes the following steps:

- Sorting: collected textiles are manually sorted and graded according to their condition and the types of fibres used.

- Wearable textiles: Shoes and clothes are resold either in the same country of origin or abroad.

- Unwearable textiles: These are sold to the "flocking" industry for shredding and re-spinning.

- Re-sorting: Mills-grade incoming material according to their type and colour. The colour sorting means no re-dying is needed, saving energy and avoiding pollutants.

- Shredding and pulling: Textile materials are shredded or pulled into fibres. Depending on the end use of the yarn, other fibres may be incorporated.

- Carding: The blended mixture is carded to clean and mix the fibres.

- Spinning: The yarn is re-spun ready for later weaving or knitting.

This report focuses on different sorting and recycling technologies. It is one of three sub-reports that summarize the work from the first year of the Nordic Council of Ministers project A Nordic strategy for collection, sorting, reuse and recycling of textiles. 
The project is one of six that constitute Resource Efficient Recycling of Plastic and Textile Waste, which was launched by the Nordic Waste Group (NWG) as part of the Nordic Prime Ministers' green growth initiative, The Nordic Region - leading in green growth. Read more in the web magazine Green Growth the Nordic Way at www.nordicway.org, or at www.norden.org/greengrowth 


\section{Sorting technologies}

Sorting is the first step in the recycling process. According to the Bureau of International Recycling, the main purpose of the sorting process is to grade the textiles based on their condition and fibers types utilized (BIR 2013). Usually, sorting is performed manually, primarily separating wearable textile from unwearable. The first category include shoes and clothes that can be resold in the same country or abroad, the second category consist of textiles that are sold to industry for shredding and re-spinning.

Sorting is the first step of the recycling process and re-sorting might follow. In this last case, textile waste is sorted in relation to type and color. The benefit of re-sorting is that it is not necessary to re-dye the material, avoiding environmental emissions and saving energy.

In the manual sorting, the selection of garments is not only based on the technical quality, but also on the type of fabric. Cotton e.g. is difficult to resell, but it is a very good fabric for industrial wipes.

An example of a typical sorting facility is KICI in the Netherlands. Garments are sorted in wearable and unwearable by professional sorting companies. The wearable clothes are reused in Netherlands or in eastern European countries or donated to social food banks. The income from the textile collection is donated completely to charity e.g. to Red Cross (social benefits). For the sorted unwearable clothes, KICI is active in searching for alternatives to low grade recycling such as insulation material.

In the first stage, the sorting of fibre is done by a simple touch from the operator (there is a different feeling when wool and cotton are touched e.g.). This process requires experienced sorters and textiles that consist of multiple fibre types may be hard to recognise and characterise.

In Europe and USA, manual sorting is a costly process. In low cost countries such as Asia and Africa, manual sorting is less expensive. However, exporting textiles to low cost countries for sorting may imply logistic challenges and might raise issues with social problems related to workers exploitation, child labour, low payment etc.

Even if the manual sorting is still dominant, efforts are made for finding new sorting system, making this process automatic. In a recent EU project a machine able to sort automatically post consumers unwearable textile, i.e. "any type of garment or household article made from manufactured textiles that the owner no longer needs and de- 
cides to discard" (Hawley 2006) is built as a result of the European Union Textiles 4 Textiles-project (T4T 2013) in Netherlands. This machine is able to sort the textile waste by chemical composition (cotton, wool, polyester etc.) and color. A demo is available at the T4T website. ${ }^{22} \mathrm{KICI}$ is a partner of the T4T-project.

The technology used is based on an optical method: NIRspectroscopy (Near-infrared spectroscopy). NIR is a spectroscopic ${ }^{23}$ method that uses the near-infrared ${ }^{24}$ region of the electromagnetic spectrum. ${ }^{25}$ This technique is already applied for in sorting other material types for recycling, such as plastics. There are current developments in NIR technology to be able to identify different hazardous substances but this is today mostly done for plastics (Bilitewski et al., 2010). Future developments may be applicable for textiles.

T4T has developed a "sorting algorithm", guaranteeing to the buyer of the sorted textile the quality and the origin. This method is appropriate for making new textile from low grade textile and producing valuable products as clothes, home textiles, while short fibers can be used for insulation and automotive applications. In a pilot project for jeans production, energy and emissions saving have been calculated highlighting that the saving of $53 \%$ for energy; $99 \%$ for water and $88 \%$ for chemicals (Jongerius, 2012).

The advantages of this new technology are (Jongerius, 2012):

- the creation of new textile from old textile

- increased quality of reused fibers

- energy saving

- applicable at industrial scale.

The automated sorting technology cannot replace the preliminary manual sorting of the re-usable and not re-usable clothes.

\footnotetext{
22 http://www.textiles4textiles.eu/what-is-t4t

$23 \mathrm{http} / / /$ en.wikipedia.org/wiki/Spectroscopic

24 http://en.wikipedia.org/wiki/Infrared

25 http://en.wikipedia.org/wiki/Electromagnetic_spectrum
} 
Figure 7 NIR -spectroscopy in the sorting machine of T4T project

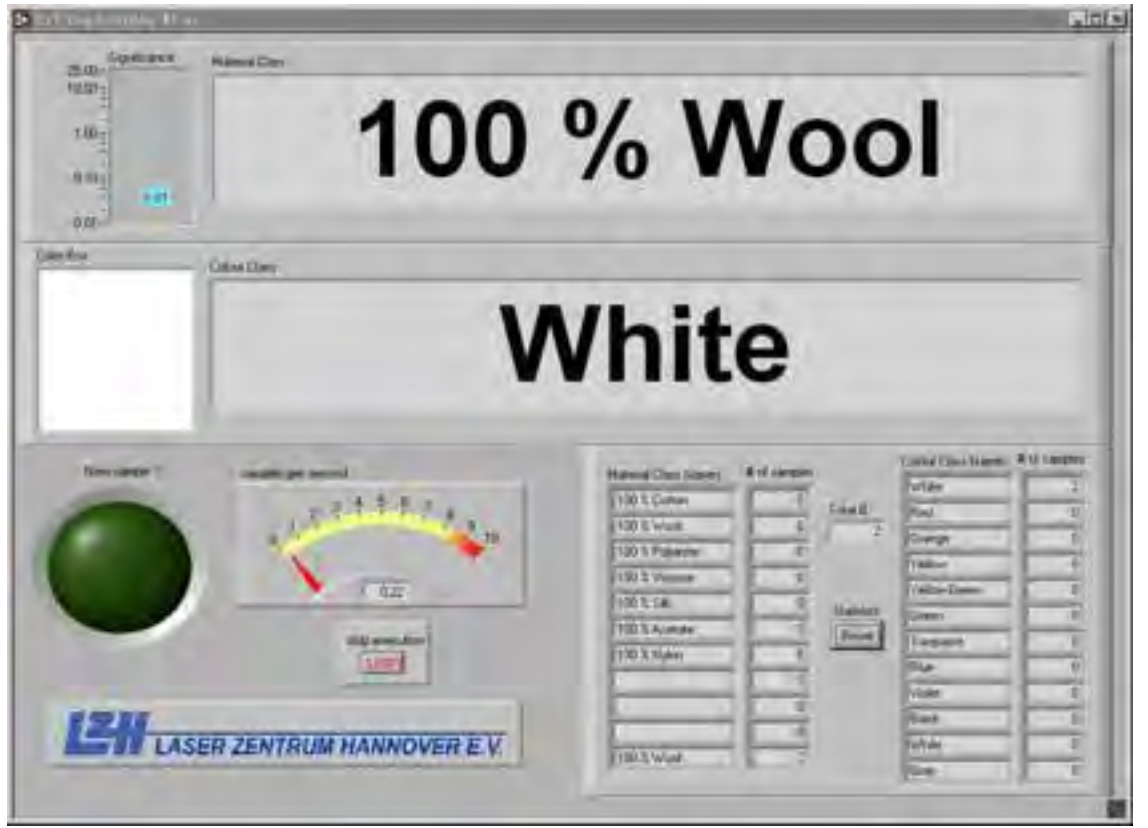

The advantages and disadvantages of the different sorting techniques are listed in Table 38.

\begin{tabular}{|c|c|c|}
\hline Sorting techniques & Advantages & Disadvantages \\
\hline \multirow[t]{4}{*}{ Manual sorting } & $\begin{array}{l}\text { Traditional technique, lots of } \\
\text { experience }\end{array}$ & Costly in Europe and USA \\
\hline & & $\begin{array}{l}\text { Less costly in Africa and Asia, but logistic and } \\
\text { social issue }\end{array}$ \\
\hline & & Based on the skills of the operator \\
\hline & & Difficult to recognize multiple fiber sorts \\
\hline \multirow{6}{*}{$\begin{array}{l}\text { Automatic: } \\
\text { Optical sorting (NIR) }\end{array}$} & Automatic; & Only for Low grade textile; \\
\hline & $\begin{array}{l}\text { Guarantee of sorted origin for } \\
\text { consumer }\end{array}$ & Preliminary sorting is still necessary \\
\hline & Industrial scale & \\
\hline & Increase quality of reuse fibers & \\
\hline & $\begin{array}{l}\text { Reduce emissions compared } \\
\text { to manual sorting }\end{array}$ & \\
\hline & $\begin{array}{l}\text { Energy and water saving } \\
\text { compared to manual sorting }\end{array}$ & \\
\hline
\end{tabular}


The automatic sorting (NIR) technology is a newly developed system and it is likely that a period of testing and optimization is necessary before the technology can be widely used. There is likely no other such system operating globally and textiles are normally manually removed before entering sorting systems with similar technology.

Automatic sorting systems applied for other materials (especially for plastics) might have the potentiality to be applied in the textile field. In the plastic sector, e.g. a way of sorting is optically by X-ray, CCD camera or optoelectronic systems. These techniques are listed and described in Table 4, (AWAST 2004).

\begin{tabular}{lll}
\multicolumn{2}{l}{ Table $\mathbf{4}$ Optical sorting in the plastic sectors } \\
$\begin{array}{l}\text { Sorting technique } \\
\begin{array}{l}\text { X-ray detector: XRT (X-ray } \\
\text { transmission) and XRF (X- } \\
\text { ray fluorescence) }\end{array}\end{array}$ & $\begin{array}{l}\text { Identification by the spectral } \\
\text { transmission characteristic of the } \\
\text { material }\end{array}$ & $\begin{array}{l}\text { PVC separation, Identification of } \\
\text { aluminium and magnesium }\end{array}$ \\
$\begin{array}{l}\text { CCD camera with digital } \\
\text { imaging }\end{array}$ & Identification by resolution & Mix packaging \\
Optoelectronic systems & $\begin{array}{l}\text { Identification by colour of } \\
\text { transparent items }\end{array}$ & $\begin{array}{l}\text { Glass; } \\
\text { Division of non transparent compo- } \\
\text { nents from glass }\end{array}$ \\
\hline
\end{tabular}

There has been found no examples of the sorting technologies above applied on textiles. The techniques will most likely require adjustment and optimization to be suitable for textile sorting, and some of them may not be applicable to textiles at all. 


\section{Recycling technologies}

Recycling of textiles represent quite recent technologies compared to other materials, even though (as for recycling of other materials) recycling of textiles has several environmental benefits:

- Decreased amount of waste going to landfill.

- Use of recycled materials rather than virgin material leads to.

- Reduced consumption of energy and water.

$\circ$ Reduced emissions (of $\mathrm{CO}_{2}$ and other).

As for other materials, the largest environmental benefit for recycling of textiles is accomplished closed loop recycling (recycling textiles into new textiles), but there are also benefits connected to recycling of textiles into other products (downcycling).

There are several different technologies available for recycling of textile waste. Four main technology pathways are listed and described below in Figure 8.

Figure 8 Main technology pathways used for recycling textile waste today

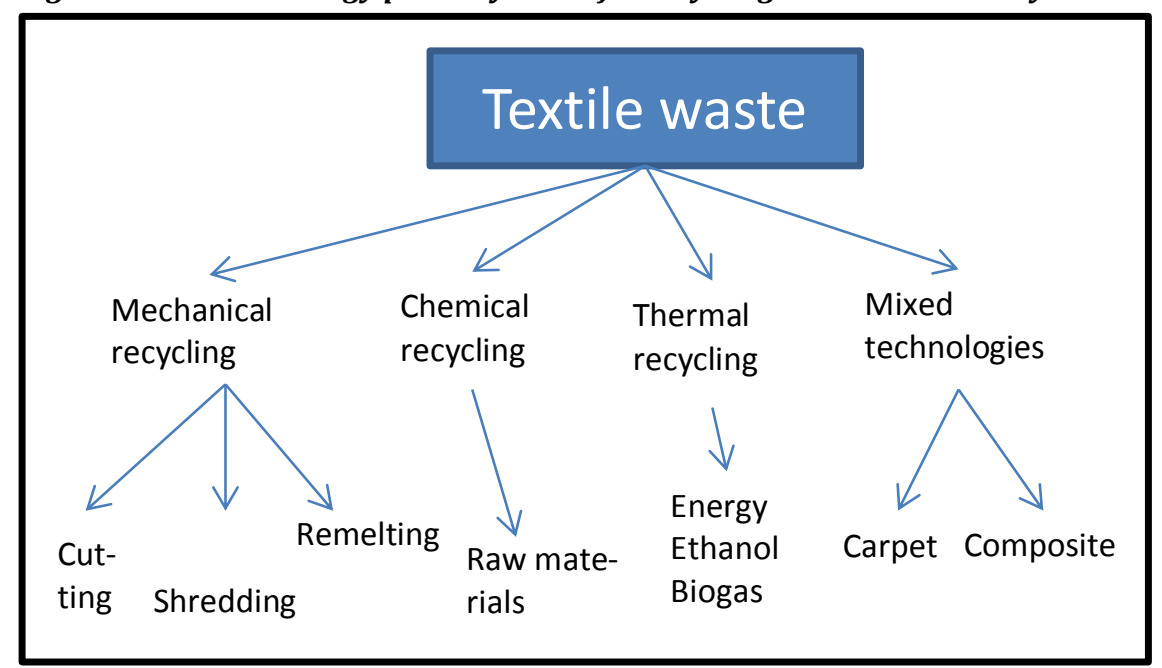

Source: Guignier, 2013. 
The four different recycling technologies are described in the following chapters.

\subsection{Mechanical recycling}

In Europe, most of the textile waste is recycled mechanically for producing fillings in mattresses and for upholstery. Other common applications are insulation material or capillary matting products (Zamani, 2011).

Mechanical recycling means breaking down a fabric to fibres through cutting, shredding (size reduction from big pieces to small pieces), carding and other mechanical processes. Mechanical separation can be achieved through separation based on density difference of fibres and/or centrifugation and/or melting. A scheme of the mechanical recycling process stages is shown in Figure 9.

Figure 9 Mechanical recycling process stages

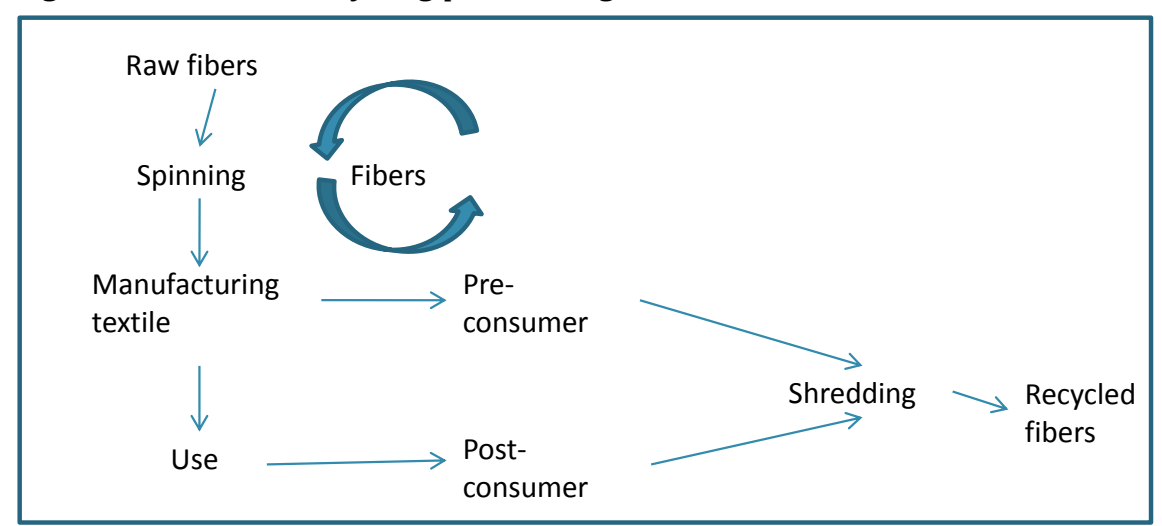

Mechanical recycling is done performed by companies such as SOEX and the BOER group with the material used in for example Renault vehicles. There are different mechanical techniques for recycling of textiles (Zamani, 2011):

- Technique for producing fabrics.

The textile waste is deconstructed in a high quality fabrics remanufacturing process, and converted into a new products such as wallets or slippers. This is also known as remanufacturing and performed by charities such as the Swedish Red Cross (Dahlin 2013) and companies such as Worn Again (Ryan 2013). 
- Technique for producing fibres.

The textile waste goes through a cutting process and passed through a drum for achieving fibres. Further, fibres are cleaned and mixed with virgin fibres. Yarns produced from recycled textiles with poor physical properties consist mostly of mixed colour fibres and various fibre lengths. The final products from recycled textile having poor quality are synthetic textiles, such as woven filtration systems or geotextiles, having mixed colour fibres and different fibre lengths. This is not very common due to the often poor quality of the fibres produced but have been done by KICI and sold as G-Star Raw Recycled jeans (Jansen 2013).

- Technique for producing yarn.

Textile waste may be utilized to produce yarn, but the quality of the yarn is dependent by the properties of the fibres. The textile waste is cleaned, cut and re-melted before it is spun into yarn. The final products are utilized for producing nonwoven products such as sound and heat insulation materials in automotive industry, upholstery, carpet underlay, disposable diapers, napkins and tampons. Yarns made from this type of fibers are mainly dark or gray, hence not typically found in household. The textile can be converted both in high quality products used in sheeting, furnishing and apparel or in low quality material for wiping and fillings. This technology is not commonly used in Europe for textile waste but is mostly for producing yarn from PET-bottles and similar waste (Oerlikon 2013). The largest recycler is Panipat in India which produce low quality blankets from recycled yarn (Norris 2012).

\subsection{Chemical recycling}

During chemical recycling the fibres in the textiles are broken at molecular level and the feedstock is repolymerized (Fletcher 2008). Chemical recycling is used for synthetic fibres (polyester, nylon etc.) or mixed fibre (synthetic and natural). The fibres are chemically separated from the original textile. In case of pure cellulosic materials the degradation is made by enzymatic or acid hydrolysis. Polyester and polyamide are recycled as below in Figure 10. 
Figure 10 Chemical recycling process stages

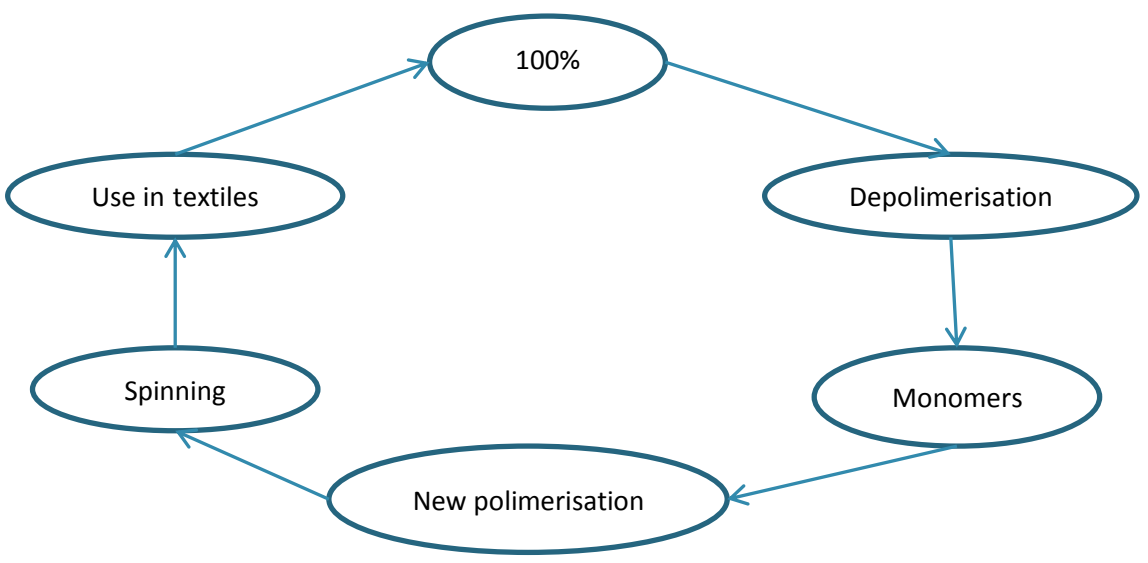

Source: Guignier, 2013.

Chemical recycling requires more energy than mechanical recycling, but at the same time the quality of the fibres is more predictable. The use of the final products is various from the car sector such as upholstery to home furnishing.

In the future it is expected an improvement of the repolymeration of recycled synthetic fibre. A promising example of chemical recycling is Re:newcell in Sweden. Re:newcell process indicates the method when textiles are chemically treated to produce regenerated cellulose (pulp) and later transformed in intermediate product viscose fiber. The Re:newcell recycling method deals with cellulosic fibers. Cotton, viscose and elastane (spandex) fibers are recycled into regenerated viscose fibers with a near to full recycling rate regarding pure cotton. Textiles are torn mechanically and processed in a chemical solution. Unwanted contaminants such as polyester, zippers and buttons are removed. The cellulose is dissolved in an alkali solution and the filtered into a slow-flowing pulp from which new viscose can be produced (KTH 2012). The recycling is further described in Youhanan' thesis (Youhanan 2013). The recycling is said to start at pilot scale during 2013 or 2014 (Renewcell 2012) but little information is available on the progress of the technology. Renewcell states that they are looking for large quantities of pure cotton that is white or light colored which implies that larger scale tests are being scheduled (Brismar 2013a). Small scale tests with a mix of pants (cotton), jeans, tshirts, shirts and towels (of more than 50\% cotton in total) from charities are to be executed in December 2013 with the aim of investing the chemical prospects for recycling (Brismar 2013b). 
Examples of a closed loop recycling is found in Japan where Teijin Fibers Ltd since 2002 produces garment consisting of $100 \%$ recycled polyester (Teijin 2013) End-of-life polyester garment are transformed in raw material having similar quality as the original raw material. Hence, the end products are high quality garments including materials having specific characteristics as highly flame resistant material. ECOCIRCLE ${ }^{\mathrm{TM}}$ polyester is broken down and granulated into small pellets, before the recycling phase. These pellets are decomposed using chemicals and returned into the raw material (DMT, dimethyl terephthalate) which can then be polymerized and spun into new ECOCIRCLE ${ }^{\mathrm{TM}}$ polyester fibres. $100 \%$ polyester material and polyester-rich garment can use this system. Teijn has calculated a reduction of energy consumption by $84 \%$ and $\mathrm{CO}_{2}$ emissions by $77 \%$, by theesubstituion of virgin material. However, the manufacturing cost for ECOCIRCLE ${ }^{\mathrm{TM}}$ is about $10-20 \%$ more expensive than the ones of virgin material. The reasons are mainly in higher production costs and investment in the technologies and machineries.

Another example of chemical recycling of synthetic fibers is Asahi Kasei Fibers (Asahi-KASEI 2007) with a product called ECOSENSOR ${ }^{\mathrm{TM}}$. The material is made from polyester fibres chemically recovered from recycled polyester textiles and PET films and bottles. The polymer of the used products is broken down, creating new pure polymers. The final products are innerwear, outerwear, work uniforms, components, linings and sportswear. The product is available but not actively marketed which might suggest production issues.

There has been research on using the Lyocell process for chemical recycling of cotton by using the chemical $\mathrm{N}$-methylmorpholine- $\mathrm{N}$-oxide (NMMO). This process is normally used for dissolving wood pulp to extract Lyocell fibres (Shen and Patel M, 2010). The process could possibly separate cellulose (cotton, viscose) from polyester for further recycling (Zamani 2011). No actual recycling with this process has been identified.

Chemical recycling is in most cases performed in pilot scale, with the exception of Teijins ECOCIRCLE.

\subsection{Thermal recovery}

Thermal recovery is the process of converting textile waste to energy and not a recycling technology as such. Cotton textiles e.g. are cut in pieces, compacted, pelletized and used as fuels in boilers. Textile waste may also be used in biogas production (example from Valagro for cotton 
waste). Waste to incineration is a good alternative to landfill, but should otherwise be used only for textiles not suitable for recycling.

University of Borås have developed technology to transform cotton based waste textile into biogas or ethanol and was able to extract about 0.5 $\mathrm{kg}$ of ethanol or 380L methane from $1 \mathrm{~kg}$ of cotton (Borås University 2013).

\subsection{Mixed technologies}

In mixed technologies more than one technique is used in the recycling process. An example is recycling of carpets, where both mechanical and chemical techniques are utilized. Carpet, in fact, is a complex product that is very difficult to recycle, but many technologies are developed specifically for carpet (Wang 2010).

Mechanical and chemical recycling can represent both "open loop recycling" or "closed loop recycling". In the first case, it is referred to "the process of mechanically or chemically 'opening' the fabric so as to return it to a fibrous form and it can be further processed into new products for renewed consumption."

In the "close loop recycling approach" the recovered raw material used for producing a polymer (in the synthetic fibres) is reprocessed in a same product having similar quality. For manufacturing this polymer product it is necessary to use raw material and energy, and especially the last one is high in the energy conversion step. Hence for some polymers materials this system is not feasible, but a great development is expected in the future.

In the Table 5, the advantages and disadvantages of each recycling technique and future challenges/trend are presented. 


\begin{tabular}{|c|c|c|c|}
\hline $\begin{array}{l}\text { Recycling } \\
\text { technologies }\end{array}$ & Advantages & Disadvantages & Challenges/trend \\
\hline $\begin{array}{l}\text { Mechanical } \\
\text { recycling }\end{array}$ & $\begin{array}{l}\text { Less expensive } \\
\text { Lowest energy use among all } \\
\text { techniques } \\
\text { Lowest number of impacts } \\
\text { among all techniques }\end{array}$ & $\begin{array}{l}\text { Few yarn denier options (more } \\
\text { impurities) } \\
\text { Streakiness in dyeing } \\
\text { Few times because the molecular } \\
\text { structure can break down and } \\
\text { cannot be used for textile }\end{array}$ & \\
\hline $\begin{array}{l}\text { Chemical } \\
\text { recycling }\end{array}$ & $\begin{array}{l}\text { Larger choice of yarn denier } \\
\text { and less impurities } \\
\text { Recycled as long as you want }\end{array}$ & $\begin{array}{l}\text { More expensive } \\
\text { Higher energy consumption }\end{array}$ & $\begin{array}{l}\text { Improvement of } \\
\text { the repolymera- } \\
\text { tion of recycled } \\
\text { synthetic fiber. }\end{array}$ \\
\hline $\begin{array}{l}\text { Thermal } \\
\text { Recovery }\end{array}$ & $\begin{array}{l}\text { Good alternative to landfill } \\
\text { Good alternative for textile } \\
\text { waste with unknown } \\
\text { composition }\end{array}$ & $\begin{array}{l}\text { Problematic with harmful sub- } \\
\text { stances (ash and } \mathrm{N} \text { oxides) } \\
\text { Efficiency of incineration }\end{array}$ & $\begin{array}{l}\text { Improvement of } \\
\text { the efficiency and } \\
\text { reduction of } \\
\text { harmful substanc- } \\
\text { es during the } \\
\text { burning }\end{array}$ \\
\hline $\begin{array}{l}\text { Mixed } \\
\text { recycling }\end{array}$ & $\begin{array}{l}\text { Dependens on the mixed } \\
\text { techniques }\end{array}$ & $\begin{array}{l}\text { Dependens on the mixed } \\
\text { techniques }\end{array}$ & \\
\hline
\end{tabular}

\subsection{Special processes}

Depending on the final application, fibres sometimes do not need to be spun into yarns: They can simply be compressed to create new textile fillings. In the case of polyester-based materials, the recycling starts by cutting the garments into small pieces. The shredded fabric is then granulated and turned into polyester chips. The chips are melted and spun into new filament fibres used to make new polyester fabrics.

\subsubsection{Applications}

- Knitted or woven woollen and similar materials are reused by the textile industry in applications such as car insulation, roofing felt, loudspeaker cones, panel linings and furniture padding.

- Cotton and silk is used to manufacture paper and to wiping and polishing cloths for a range of industries from the automotive to the mining sector.

- Other types of textiles can be reprocessed into fibres for upholstery, insulation, and even building materials. 



\section{Summary and conclusions}

Large scale recycling available are mostly mechanical, with shredding into insulation as the main technique. Simple cutting into rags is also a common recycling. These have a limited environmental benefit since they represent a downcycling rather than a closed loop recycling process. Closed loop recycling seems to be more achievable for synthetic fabrics and as a large share of textiles consist of synthetic materials this may be a future opportunity for sustainable technology development. This requires well developed sorting technologies.

In UK, DEFRA (Morley et al., 2009) has registered a decline in the textile recycling, and one explanation is the appearance of the recycled material compared to the virgin ones. In Europe, most of the textiles are mechanically recycled and the main end products are mattress and upholstery, carpets and products for car industry. In a small amount, recycled material is used for basket liners and thermal insulation. The market for these types of recycling products is mature, so there are no expectations of improvement. The main problems are linked to low quality of recycled fibers and fabrics, making it preferable to use virgin material. The Nonwovens Innovation \& Research Institute Ltd76 (NIRI) has led a study for looking at new technologies in the recycling of textile, finding out very little progress in the technological development and little research in this field.

In general, the largest obstacles in the recycling and sorting technology development are in the low value of the end products and in the various quality of the raw material such as mixed fibers with different mechanical and physical properties.

In the Nordic countries it seems that the market for textile waste for recycling is almost inexistent, due to the lack of recycling technologies available and high cost for this operation. There are few operational high grade recycling techniques available to the market at present. There are however a few technologies, especially Re:newcell, that show promising possibilities in the future. The actual performance is though yet to be seen for these technologies with reference to losses, chemical use and energy use in full scale recycling.

The Nordic region seems to have a possibility to advance in the recycling of textile, not only for its' own textile but for the European market. 
The work performed on recycling technology, however, needs to intensify to provide good recycling solutions for the textiles not suitable for reuse. The focus should be on high quality end products with a market demand, to ensure both economic and environmental sustainable recycling processes. 


\section{References}

Asahi-KASEI (2007). Ecosensor. http://www.asahi-kasei.co.jp/fibers/en/

AWAST (2004). Deliverable 10. Methodology for evaluating the overall efficiency of sorting in Europe, comparable data and suggestion for improving process efficiency analysed within the project. EC Fifth framework programme project AWAST. Available at: http://ec.europa.eu/environment/eco-innovation/files/docs/infod/2012/ nov/8_t4t_brussels_presentation.pdf

Bilitewski, B.; Barceló, D.; Darbra, R.M.; v.d. Voet, E.; Belhaj, M.; Benfenati, E.; Ginebreda, A.; Grundmann, V. (2010). Risk-based management of chemicals and products in a circular economy at a global scale. RISKCYCLE project deliverable 2.1. Hanoi 2010.

Bir. (2013). http://www.bir.org/industry/textiles/

Borås University (2013). Waste Textiles to Ethanol and Biogas. Available at: http://www.hb.se/en/School-of-Engineering/Research/Resource-Recovery/ More-information-about-Resource-Recovery/Biotechnology/ Waste-Textiles-to-Ethanol-and-Biogas/

Brismar A. (2013a). Personal communication with Anna Brismar, consultant for Renewcell 2013-10-10.

Brismar A. (2013b). Email to charities 2013-12-12 from Anna Brismar.

Dahlin, E. (2013). Personal communication with Elisbeth Dahlin, Swedish Red Cross.

Fletcher, Kate.(2008). Sustainable Fashion and Textiles: Design Journeys. London: Earhscan.

Guignier, C., (2013). Textile Recycling: An Overview on Technologies and Tendencies Applications. International Textile \& Apparel Association. Vol 24 No 3 p1-14.

Hawley, J. M. (2006). Digging for Diamonds: A conceptual Framework for Understanding Reclaimed Textile Products.

Institute of Textile Science (ITS). (2013) Groupe CCT Group. 110th Scientific Session - Saint- Hyacinthe, Québec.

Jansen, A (2013). Personal communication with André Jansen, KICI foundation.

Jongerius, S. (2012). Textiles 4 textiles contribution to Eco innovation. Presentation Brussels November 8 2012. KICI.

KTH (2012). Slut på textil-slöseriet - Tekniken som lyckas återvinna tyg. Available at: http://www.kth.se/forskning/pa-djupet/slut-pa-textil-sloseriet-1.342018

Morley, N., McGill, I. and Bartlett, C. (2009). Maximizing reuse and recycling of UK clothing and textiles.

Norris, L. (2012). Recycling imported secondhand textiles in the shoddy mills in Panipat, India: an overview of the industry, its local impact and implications for the UK trade, A research summary by Lucy Norris, Department of Anthropology, UCL, February 22, 2012, http://www.wornclothing.co.uk/wp-content/uploads/2011/01/ SummaryShoddy.pdf

Oakdend Hollins Ltd,. (2009). Final report for DEFRA, Available at: http://www.oakdenehollins.co.uk/pdf/defra_173_summary_issue_4.pdf

Oerlikon (2013). Fibers and filaments - the Experts magazine. Issue 16th August 2013. 
Pesnel, S., and A. Perwuelz. (2013). "LCA: a Decision-making Tool for Recycling Processes in Textile Industry". LCM conference proceeding.

Renewcell (2012). Re:newcell AB etablerar sig på Wargöns industriområde. Press announcement 31st May 2012.

Ryan, N (2013). Personal communication with Nick Ryan, Worn Again.

T4T. (2013). http://textiles4textiles.eu/

Teijin (2013). Closed-loop Recycling System: ECO CIRCLE. Available at: http://www.teijin.com/solutions/ecocircle/

Wang, Youjiang. (2010). "Fiber and Textile Waste Utilization.” Waste and Biomass Valorization 1 (1) (February 4): 135-143.

Youhanan, Lena. (2013). "Environmental Assessment of Textile Material Recovery Techniques Examining Textile Flows in Sweden”. Master of Science Thesis Stockholm.

Zamani, B., (2011). Carbon footprint and energy use of textile recycling techniques Case study: Sweden. Master of Science Thesis. Department of Chemical and Biological Engineering Chalmers University of Technology, Göteborg, Sweden. 


\section{Towards a Nordic textile strategy}

This report is the primary outcome from Part I of the project "Towards a Nordic textile strategy - Collection, sorting, reuse and recycling of textiles" initiated by the Nordic Waste Group (NAG). The report for Part 2 will be published in December 2014.

This report summarizes the work carried out in 2013. The three subreports will be the basis for the work to be performed in 2014 . The reports for 2013 are:

- International market survey of textile flows in the Nordic region and the market for collection, sorting, preparing for reuse, reselling and waste management of textiles.

- Collection and sorting systems A total of 19 collection systems are compared for collection flows, contamination levels, cost, suitability of collected textile and availability for the consumer. Four sorting systems are described.

- Technology review of sorting and recycling of textiles that describes available and future technology.

The report is part of the Nordic Prime Ministers' overall green growth initiative: "The Nordic Region - leading in green growth." Read more in the web magazine "Green Growth the Nordic Way" at www.norden.org/ greengrowth. 